\title{
Nitrate in Ground Water and Spring Water near Four Dairy Farms in North Florida, 1990-93
}

\section{By William J. Andrews}

U.S. GEOLOGICAL SURVEY

Water-Resources Investigations Report 94-4162

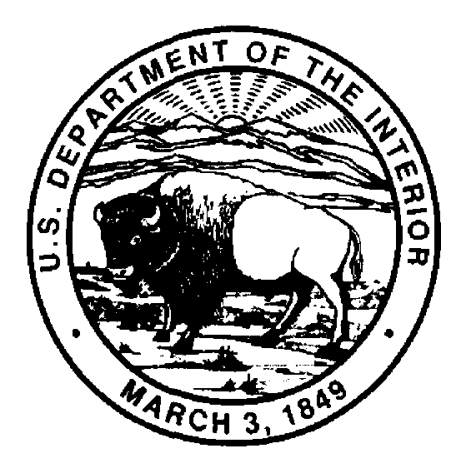




\title{
U.S. DEPARTMENT OF THE INTERIOR BRUCE BABBITT, Secretary
}

\author{
U.S. GEOLOGICAL SURVEY \\ Gordon P. Eaton, Director
}

\begin{abstract}
Any use of trade, product, or firm names in this publication is for descriptive purposes only and does not imply endorsement by the U.S. Geological Survey.
\end{abstract}

For additional information write to:

District Chief
U.S. Geological Survey
Suite 3015
227 North Bronough Street
Tallahassee, Florida 32301
Copies of this report can be purchased from:

U.S. Geological Survey Earth Science Information Center Open-File Reports Section P.O. Box 25286, MS 517 Denver, CO 80225-0425 


\section{CONTENTS}

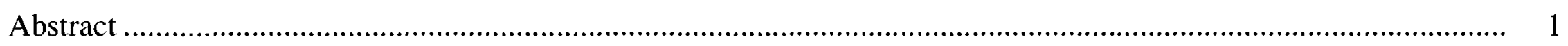

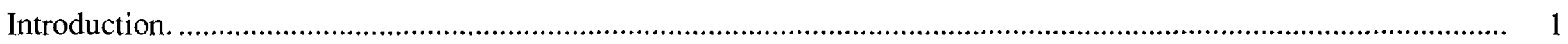

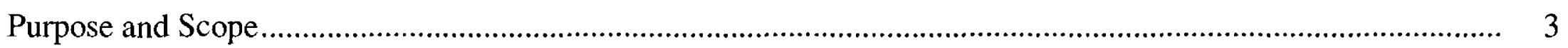

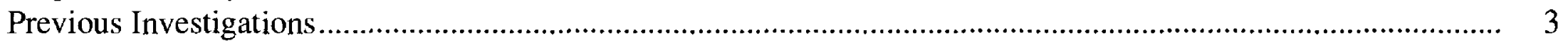

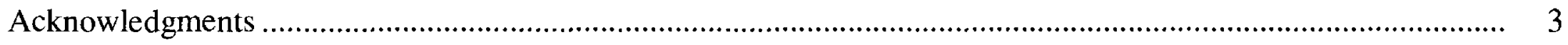

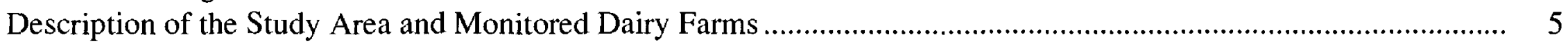

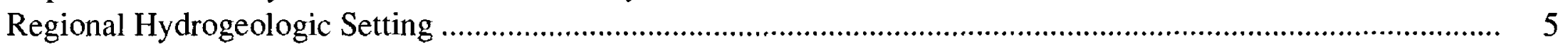

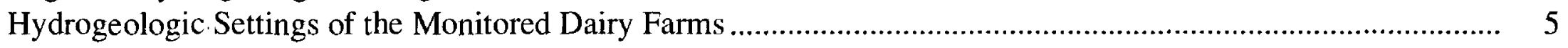

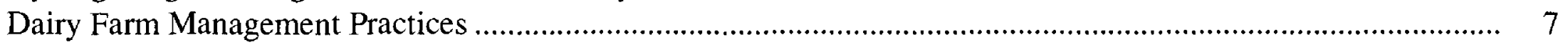

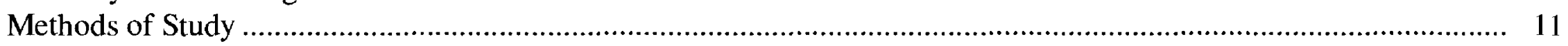

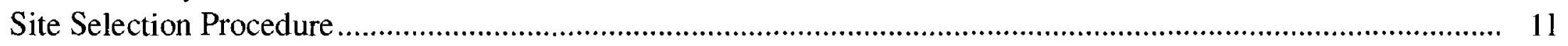

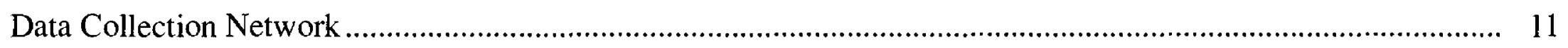

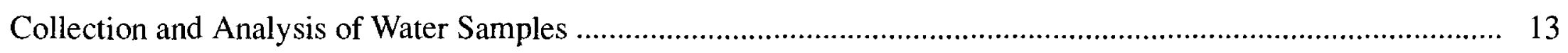

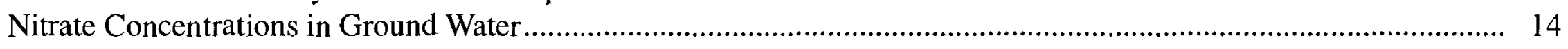

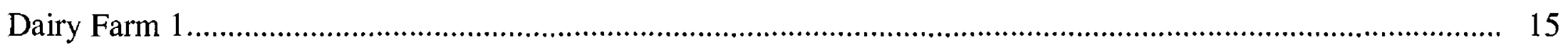

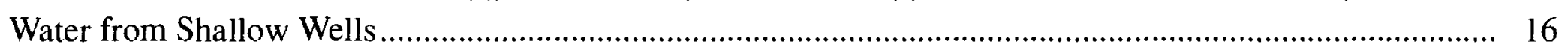

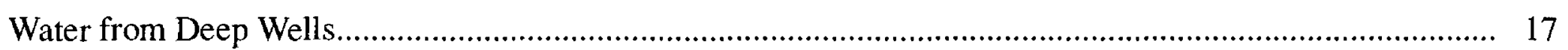

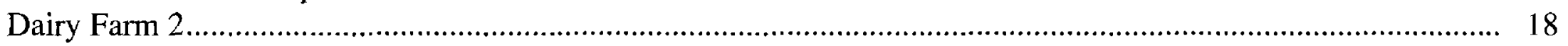

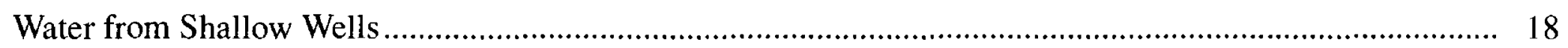

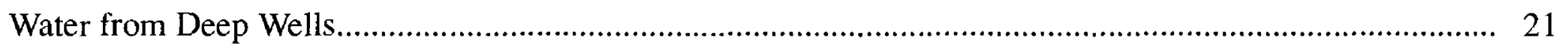

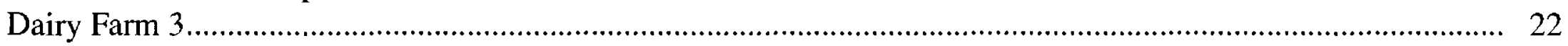

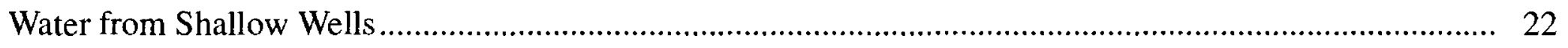

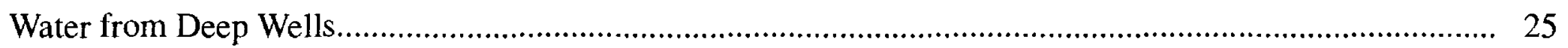

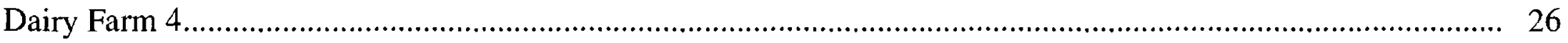

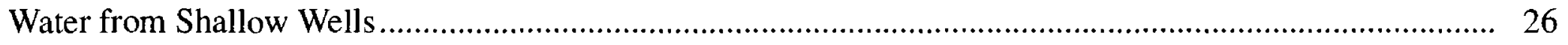

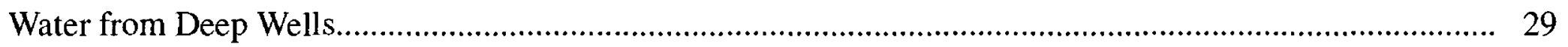

Nitrate Concentrations in Spring Water.......................................................................................... 30

Sources of Nitrate in Ground Water Indicated by Nitrogen Isotope Ratios ........................................................ 31

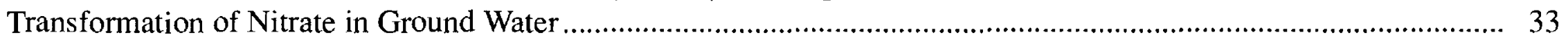

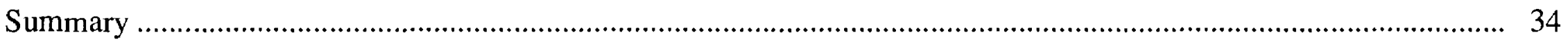

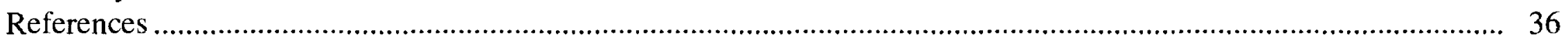

Appendix I-Water-Quality Data from Wells at the Four Dairy Farms............................................................. 41

Appendix II--Water-Quality Data from the Three Monitored Springs ..........................................................63

\section{FIGURES}

1. Locations of dairy farms and monitored dairy farms, springs in Lafayette and Suwannee Counties, Florida.......... 4

2. Diagrammatic hydrogeologic sections of the monitored dairy farms in Lafayette and Suwannee Counties............. 6

3-6. Maps showing:

3. Location of monitoring wells, water-table altitudes and ground-water flow directions in the surficial aquifer on April 29-30, 1992, at dairy farm 1, Lafayette County.....

4. Location of monitoring wells, water-table altitudes and ground-water flow directions in the Upper Floridan aquifer on October 28-29, 1992, and January 28-29, 1993, at dairy farm 2, Lafayette County ............... 8

5. Location of monitoring wells, water-table altitudes and ground-water flow directions in the Upper Floridan aquifer on January 26-29, 1993, at dairy farm 3, Lafayette County

6. Monitoring wells, water-table altitudes and ground-water flow directions in the Upper Floridan aquifer on October 31, 1991, and January 27, 1992, at dairy farm 4, Suwannee County 
7-17. Graphs showing:

7. Nitrate concentrations in water from wells at dairy farm 1 in Lafayette County, 1990-93

8. Nitrate concentrations in water from wells at dairy farm 1 in Lafayette County, 1991-93

9. Nitrate concentrations in water from wells at dairy farm 2 in Lafayette County, 1990-93

10. Relation between water-level altitude and nitrate concentration in water from well $2-1$ in Lafayette County, 1990-93.

11. Nitrate concentrations in water from wells at dairy farm 2 in Lafayette County, 1990-93 ...

12. Nitrate concentrations in water from wells at dairy farm 3 in Lafayette County, 1990-93

13. Nitrate concentrations in water from wells at dairy farm 3 in Lafayette County, 1991-93

14. Nitrate concentrations in water from wells at dairy farm 4 in Suwannee County, 1990-93

15. Relation between water-level altitude and nitrate concentration in water from well 4-3 at dairy farm 4 in Suwannee County, 1990-93

16. Nitrate concentrations in water from wells at dairy farm 4 in Suwannee County, 1991-93

17. Nitrate concentrations in water from Blue, Telford, and Convict Springs, Lafayette and Suwannee Counties, 1991-93

\section{TABLES}

1. Characteristics of the dairy farm monitoring wells, Lafayette and Suwannee Counties, Florida

2. Median values of selected water-quality characteristics in water from shallow monitoring wells at dairy farm 1, Lafayette County, 1990-93

3. Median values of selected water-quality characteristics in water from deep monitoring wells at dairy farm 1, Lafayette County, 1991-93

4. Median values of selected water-quality characteristics in water from shallow monitoring wells at dairy farm 2, Lafayette County, 1990-93

5. Median values of selected water-quality characteristics in water from deep monitoring wells at dairy farm 2, Lafayette County, 1991-93

6. Median values of selected water-quality characteristics in water from shallow monitoring wells at dairy farm 3, Lafayette County, 1990-93

7. Median values of selected water-quality characteristics in water from deep monitoring wells at dairy farm 3, Lafayette County, 1991-93

8. Median values of selected water-quality characteristics in water from shallow monitoring wells at dairy farm 4, Suwannee County, 1990-93

9. Median values of selected water-quality characteristics in water from deep monitoring wells at dairy farm 4, Suwannee County, 1990-93

0. Median values of selected water-quality characteristics in water from Blue, Telford, and Convict Springs, Lafayette and Suwannee Counties, Florida, 1991-93

1. Time-series water-quality data from sealed denitrification experiments of water from wells $2-6 \mathrm{~A}$ and $1-4 \mathrm{~A}$ in Lafayette County 
CONVERSION FACTORS, VERTICAL DATUM, AND

ADDITIONAL ABBREVIATIONS

\begin{tabular}{rll}
\multicolumn{1}{c}{ Multiply } & By & \multicolumn{1}{c}{ To obtain } \\
\hline inch (in.) & 2.54 & centimeter \\
inches per year (in/yr) & 2.54 & centimeters per year \\
foot (ft) & 0.3048 & meter \\
gallon (gal) & 0.003785 & cubic meter \\
gallon (gal) & 3.785 & liter \\
mile (mi) & 1.609 & kilometer \\
pound (lb) & 453.6 & gram \\
\hline
\end{tabular}

Temperature in degrees Fahrenheit $\left({ }^{\circ} \mathrm{F}\right)$ can be converted to degrees Celsius $\left({ }^{\circ} \mathrm{C}\right)$ as follows:

$$
{ }^{\circ} \mathrm{C}=(5 / 9) \times\left({ }^{\circ} \mathrm{F}-32\right)
$$

Sea level: In this report "sea level" refers to the National Geodetic Vertical Datum of 1929-a geodetic datum derived from a general adjustment of the first-order level nets of both the United States and Canada, formerly called Sea Level Datum of 1929.

\section{ADDITIONAL ABBREVIATIONS}

$\mathrm{mL}=$ milliliter

$\mathrm{col} / 100 \mathrm{~mL}=$ colonies per 100 milliliters

$\mathrm{mg} / \mathrm{L}=$ milligrams per liter

$\mu \mathrm{S} / \mathrm{cm}=$ microsiemens per centimeter

$r=$ Pearson correlation coefficient

FDEP = Florida Department of Environmental Protection

MBAS = methylene blue active substances

SCS $=$ U.S. Soil Conservation Service

UF = University of Florida, Agricultural Engineering Department

USGS = U.S. Geological Survey 


\title{
Nitrate in Ground Water and Spring Water near Four Dairy Farms in North Florida, 1990-93
}

\author{
By William J. Andrews
}

\section{Abstract}

Nitrate concentrations exceeded the primary drinking-water standard of 10 milligrams per liter as nitrogen in water samples from 24 of 51 monitoring wells sampled periodically from 1990-93 at 4 dairy farms in Lafayette and Suwannee Counties in North Florida. Consumption of water with nitrate concentrations exceeding 10 milligrams per liter has been tentatively associated with diseases such as methemoglobinemia and with increased incidence of stomach cancer and birth defects. The highest concentrations of nitrate in ground water at North Florida dairy farms were detected in water from shallow monitoring wells completed in the top 10 feet of the saturated zone downgradient from unlined wastewater lagoons and from areas of intensive cattle use. Water from shallow monitoring wells in areas with lower wasteloading rates (such as pastures), from deep monitoring wells (drilled 20 feet deeper than shallow wells), and from wells upgradient from wastewater lagoons and high-livestock traffic areas known as intensive-use areas generally had lower concentrations of nitrate, but these concentrations generally exceeded those in water from the background well network of the Florida Department of Environmental Protection, sampled as part of the ground-water monitoring program in these counties.

Nitrate and other nutrients in ground water also have the potential to cause eutrophication in the spring-fed Suwannee River, which flows between Lafayette and Suwannee Counties in North Florida. The Suwannee River has been designated an "Outstanding Florida Water" by state officials who wish to preserve the pristine quality of this river. Nitrate, with concentrations ranging from 2-7 milligrams per liter as nitrogen, was the principal nutrient in water sampled periodically from three springs discharging to the Suwannee River in the area where dairy farms were most numerous in North Florida.

Phosphorus concentrations were not elevated above background concentrations in water from most of the dairy farm monitoring wells or in ground water discharged to the River at these springs, indicating that phosphorus leached from animal waste leachate or other sources was sorbed on materials in the unsaturated and saturated zones, or was removed by biological activity.

To determine sources of nitrate in water from wells at dairy farms and springs, nitrogen isotope ratios in nitrate were analyzed in water samples from eight monitoring wells and in water samples from Blue, Telford, and Convict Springs. Nitrogen isotope ratios in nitrate indicated that animal wastes were the source of nitrate in water from wells immediately downgradient from wastewater lagoons or intensive-use areas. Nitrogen isotope ratios also indicated that the sources of nitrate in water from wells at greater distances from or upgradient from these land-use areas and in water from the three springs were either synthetic fertilizers or combinations of soil nitrogen, animal wastes, and synthetic fertilizers.

Nitrate can be removed from ground water by microbial denitrification where bacteria, in the presence of carbon sources in anoxic water, remove oxygen atoms from nitrate, creating nitrite, and nitrous oxide and dinitrogen gases. 
Although counts of denitrifying bacteria commonly exceeded several hundred thousand colonies per 100 milliliters in water samples from selected monitoring wells at dairy farms, oxygen concentrations in water samples from most of the wells were greater than $1.0 \mathrm{mg} / \mathrm{L}$, indicating that denitrification was unlikely to occur in water from many of the monitoring wells. Denitrification was more likely to occur in deeper ground water, which generally had lower dissolved oxygen concentrations than shallow ground water. To investigate the factors limiting denitrification, nitrate concentrations in three sealed groundwater samples were measured periodically for as long as two weeks after they were collected. With no treatment, denitrification, as evidenced by decreasing nitrate concentrations with time, did not occur in a water sample from a well completed in the Upper Floridan aquifer. Denitrification did not occur in a second water sample from that well until glucose, a carbon substrate, was added. Addition of glucose to a water sample from a well completed in a surficial aquifer did not induce denitrification, probably because of inhibition of the reaction by the low $\mathrm{pH}$ of the water from that well.

\section{INTRODUCTION}

The occurrence of nitrite plus nitrate nitrogen, referred to as nitrate in this report, in ground water at dairy farms in North Florida is of concern because of the potential deleterious health effects caused by elevated concentrations of nitrate in drinking water and because of the potential for nutrients such as nitrate to cause eutrophication of surface water. Consumption of water exceeding the primary drinking water standard for nitrate nitrogen of $10 \mathrm{mg} / \mathrm{L}$ (Florida Department of State, 1993) has been associated with methemoglobinemia, a condition that diminishes the ability of blood to absorb oxygen (Vigil and others, 1965; National Research Council, 1985).

Methemoglobinemia (commonly known as "blue-baby syndrome") primarily affects infants younger than six months, causing cyanosis and, in extreme cases, fatalities. Nitrate is also a precursor for carcinogenic nitrosamines and nitrosamides in human digestive tracts and elevated concentrations of nitrate in drinking water have been associated with increased incidence of stomach cancer in humans (Mirvish, 1990; Forman and others, 1985). In addition, elevated nitrate concentrations in drinking water have been tentatively associated with increased incidence of birth defects (Fan and others, 1987; Dorsch, 1984). Enrichment of ground water with nutrients such as nitrate and phosphorus, which are common constituents in leachate from livestock wastes, can also cause eutrophication, a process in which algae growth is favored and oxygen is depleted, of surface water bodies receiving inflows of ground water from springs or diffuse seepage.

Nitrate in ground water may come from many sources including: nitrate minerals, nitrogen in soils, plant debris, animal wastes, and synthetic fertilizers. Nitrate minerals, such as the well-known sodium nitrate deposits in Chile, are generally restricted to evaporitic deposits in arid environments (Ericksen, 1981). Because nitrate minerals are highly soluble in water, these minerals are unlikely to occur in areas with warm temperate environments, such as North Florida. Organic nitrogen, which is present in soils, plant debris, and animal wastes, can be converted to nitrate through the bacterially-mediated processes of ammonification and nitrification. Synthetic fertilizers, principally urea and ammonium nitrate, are commonly applied to cropland, sometimes in addition to livestock wastes, in North Florida. The sources of nitrate in water can be qualitatively determined from the ratio of nitrogen isotopes in nitrate. Nitrate is very mobile in ground water, but can be diminished in concentration by dilution or, in anoxic water, by the process of denitrification.

Nitrate is the principal contaminant of ground water in agricultural regions worldwide that are underlain by unconfined sandy aquifers or karstic carbonate aquifers, such as those in North Florida. Nitrate has been detected in elevated concentrations in ground water in agricultural areas with these hydrogeologic settings in Czechoslovakia (Pekny and others, 1989), Denmark (Pedersen and others, 1991), Great Britain (Parker and others, 1987; Wilson and others, 1990), Russia (Bashkin and Kudeyarov, 1983), and the United States (Hallberg, 1989; Madison and Brunett, 1984). Agricultural areas in the United States with similar hydrogeologic settings and elevated nitrate concentrations in ground water include the San Joaquin Valley of California (Lamb, 1986; Johnston, 1985; Page and Balding, 1973), the coastal plain of Delaware and 
Maryland (Bachman, 1984; Weil and others, 1990), Iowa (Hallberg and others, 1985: Hallberg, 1987), southeastern Minnesota (Adolphson and others, 1981; Almendinger, 1991), Nebraska (Exner and Spalding, 1990), southeastern Pennsylvania (Fishel and Lietman, 1986; Poth, 1977; Taylor and Werkheiser, 1984), and the Central Sand Plains of Wisconsin (Portage County Planning Department, 1988; Hindall, 1978; Saffigna and Keeney, 1977).

In 1989, the Florida Department of Environmental Regulation (now the Florida Department of Environmental Protection (FDEP)) reported increasing concentrations of nitrate in water from background-network wells completed in the surficial and Upper Floridan aquifers in Suwannee and Lafayette Counties in North Florida (Richard Harvey, Florida Department of Environmental Protection, oral commun., 1989). There were more than 40 dairy farms in these two counties in 1991 (fig. 1), and the population of dairy cows in Lafayette and Suwannee Counties increased from 6,400 in 1974 to 19,100 in January, 1992 (U.S. Soil Conservation Service. 1993a and b; Florida Agricultural Statistics Service, 1992). Coincident increases in the number of dairy cows and in concentrations of nitrate in water samples from background network wells in North Florida caused state officials to be concerned about the effects of livestock operations such as dairy farms on groundwater quality in the region. State officials were also concerned about possible nutrient enrichment and subsequent eutrophication of the nearby Suwannee River. The Suwannee River, one of the principal spring-fed rivers in the region, has been designated an "Outstanding Florida Water" by the State of Florida, in an effort to protect and preserve its pristine character.

In 1990, the U.S. Geological Survey (USGS), in cooperation with the FDEP, installed and sampled monitoring wells at nine selected dairy farms in North Florida to assess the effects of these farms on groundwater quality. Andrews (1992) reported elevated concentrations of nitrate (as high as $140 \mathrm{mg} / \mathrm{L}$ ) in water sampled periodically from 34 monitoring wells at these dairy farms.

\section{Purpose and Scope}

This report describes the distribution of nitrate concentrations in 620 ground-water samples from 51 monitoring wells at four dairy farms in Lafayette and Suwannee Counties in North Florida and in
19 water samples from 3 nearby springs that discharge to the Suwannee River. Water samples from the dairy farm monitoring wells and the springs were collected and analyzed quarterly during 1990-93 for the following water-quality characteristics: $\mathrm{pH}$, temperature, specific conductance. and for dissolved concentrations of nitrate, chloride, Kjeldahl (ammonia plus organic) nitrogen, ammonia nitrogen, nitrite nitrogen, oxygen, phosphorus, and inorganic carbon. Biochemical oxygen demand was also analyzed in water samples from the springs. In addition, water samples from seven selected wells were collected and analyzed monthly for these water-quality characteristics. and selected water samples were collected and analyzed for counts of denitrifying bacteria on a quarterly basis. Nitrogen isotope ratios of nitrate were analyzed in water from eight of the monitoring wells on the four monitored dairy farms and in water from the three monitored springs to qualitatively assess the source(s) of nitrate in these water samples--synthetic fertilizers, livestock wastes, soils, or a mixture of these sources. Nitrogen isotope ratios were also used to indicate the occurrence of denitrification in ground water. To assess the likelihood of denitrification occurring in ground water, concentrations of dissolved oxygen (an inhibitor of the process) were analyzed in water samples collected from 1991-93. Time-series analyses of nitrate concentrations in three sealed ground-water samples were also used to determine factors limiting denitrification in water from the surficial and Upper Floridan aquifers in North Florida.

\section{Previous Investigations}

The hydrogeology of the Suwannee River Basin has been summarized by Knapp (1978), Ceryak and others (1983), and Crane and others (1986). Numerous maps of the elevation of the potentiometric surface of the Upper Floridan Aquifer in the Suwannee River Basin, from that by Stringfield (1935) to one by Meadows (1991) have been published. Andrews (1992) reported elevated concentrations of nitrate in ground water at nine dairy farms in North Florida.

\section{Acknowledgments}

The author thanks Mr. Martin Trawick, Mr. Louis Shiver, Mr. Wyatte O'Steen, and Mr. Roy Johnson, who allowed access to their properties. The author also thanks Dr. Rodney DeHan, Mr. Phillip 

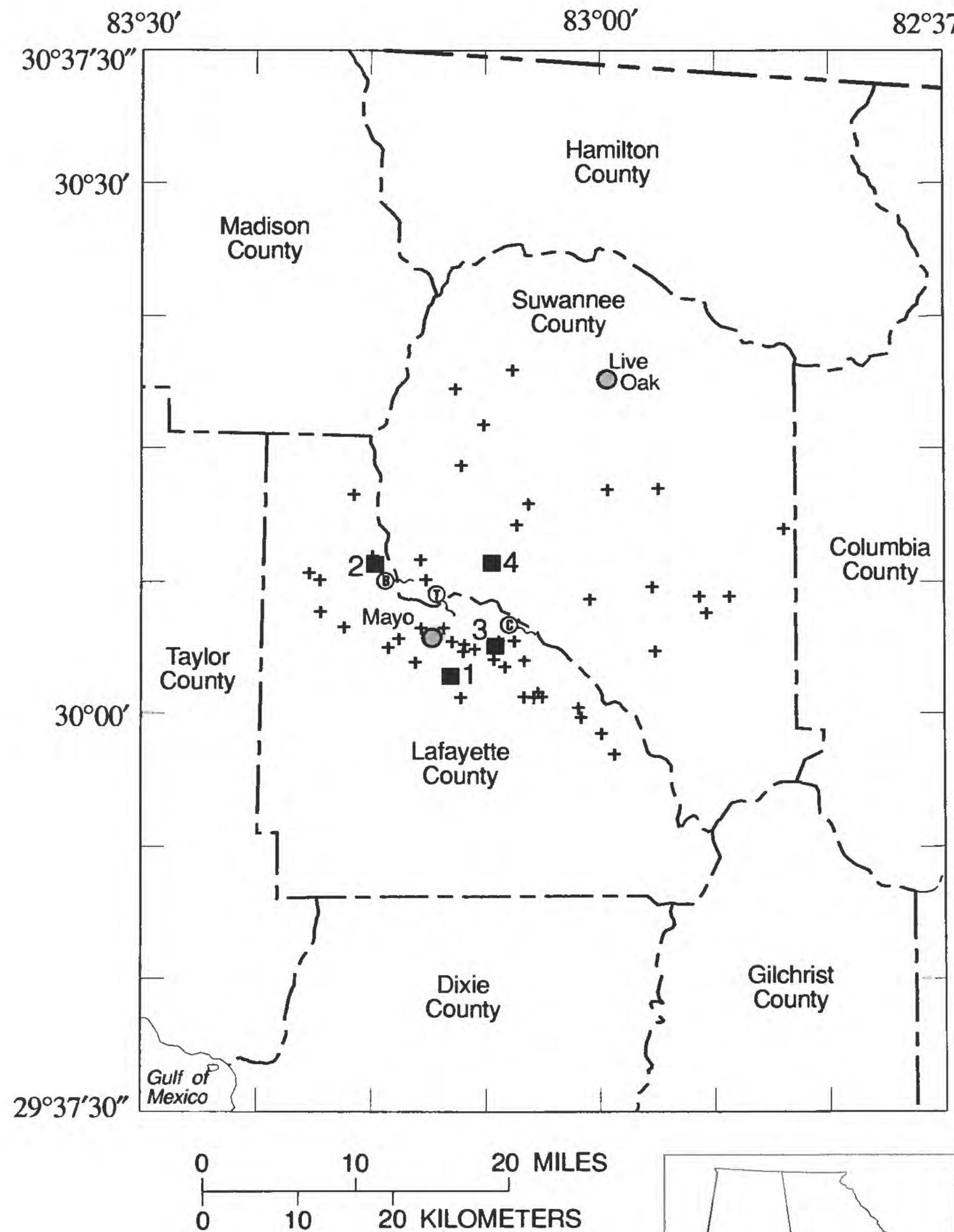

\section{EXPLANATION}

+ UNMONITORED DAIRY FARM-in Lafayette or Suwannee County, Florida

2" MONITORED DAIRY

FARM-and number used in report
(7) Blue Spring

(7) Telford Springs

(c) Convict Spring

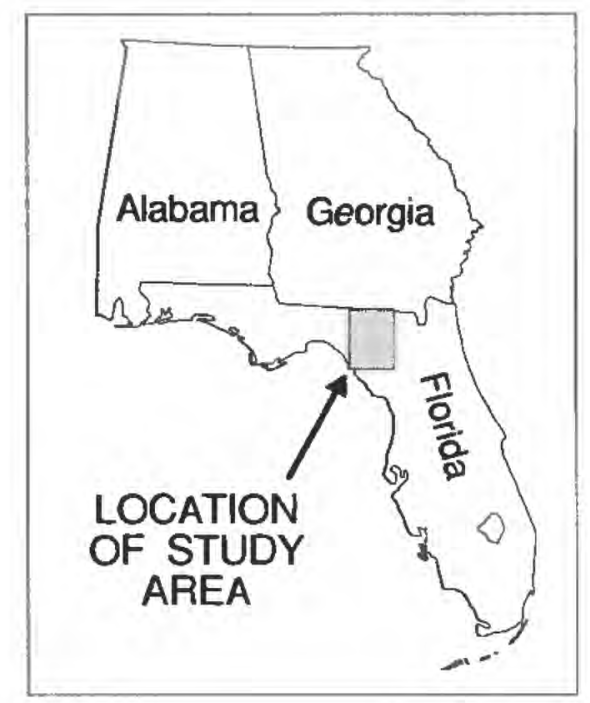

Figure 1. Locations of dairy farms and monitored dairy farms, springs in Lafayette and Suwannee Counties, Florida. 
Coram, and Mr. Mark Bardolph of the Florida Department of Environmental Protection for their interest and advice in the preparation of this report.

\section{DESCRIPTION OF THE STUDY AREA AND MONITORED DAIRY FARMS}

The hydrogeologic setting of the study area and the hydrogeologic settings of the four dairy farms monitored for this study are described in the following two sections. The dairy farms are referred to by numbers $1-4$ on the basis of the order in which well drilling occurred (fig. 1).

\section{Regional Hydrogeologic Setting}

Lafayette and Suwannee Counties, where most of the dairy farms in North Florida occur, span two general hydrogeologic settings. In the western and southwestern part of Lafayette County, a 30-40 ft thick unconfined surficial aquifer, with a water table at 5-8 ft below land surface, is underlain by the carbonate Upper Floridan aquifer. Along the Suwannee River in eastern Lafayette County and in most of Suwannee County, a $30-50 \mathrm{ft}$ thick sandy unsaturated zone is underlain by the unconfined karstic Upper Floridan aquifer (Andrews, 1992).

\section{Hydrogeologic Settings of the Monitored Dairy Farms}

Dairy farm 1 is approximately one mile south of the City of Mayo, the county seat of Lafayette County (fig.1). This farm is in the San Pedro Bay physiographic subdistrict, which is characterized by a poorly-drained terrace underlain by sandy clays of Pliocene to Pleistocene age (Brooks, 1981a). The water table in the 30- to 40-foot-thick surficial aquifer beneath this farm typically occurs at 5-8 $\mathrm{ft}$ below land surface. The surficial aquifer at this farm is underlain by the calcareous Upper Floridan aquifer. The composition of the uppermost part of the Upper Floridan aquifer at this farm ranges from a finegrained shell hash to a sequence of thinly bedded clays and micritic limestone. The upper section on figure 2 is a schematic representation of the hydrogeologic setting of this dairy farm 1.

Ground-water gradients and directions of ground-water flow at dairy farm 1, as determined from quarterly measurements of water levels in the surficial aquifer, were variable, but water in this aquifer generally flowed toward the southeast (fig. 3). Vertical gradients, as measured at pairs of shallow and deep wells at this farm (app. I), indicated that water in the surficial aquifer flowed downward toward the underlying Upper Floridan aquifer.

The unconfined karstic hydrogeologic setting of dairy farms 2, 3, and 4 (see lower section in fig. 2) is typical of most dairy farms in North Florida. These farms are in the Lower Suwannee River Valley physiographic subdistrict, the hydrogeologic setting of which is characterized by varying amounts of sands of Pliocene-Pleistocene age overlying the Suwannee Limestone of Oligocene age or the Ocala Limestone of Eocene age (Brooks, 1981a,b). These farms are generally underlain by $35 \mathrm{ft}$ of unsaturated silty sands and 5-10 ft of discontinuous clays. The Upper Floridan aquifer, which typically consists of $10 \mathrm{ft}$ of shell hash overlying fine-grained, well-cemented, cavernous karstic dolomitized cherty limestone, is the uppermost aquifer beneath these farms. At topographic high points at these farms, scattered pinnacles of unsaturated dolomitized limestone commonly are present within a few feet of the land surface.

Water in the Upper Floridan aquifer beneath dairy farm 2 flowed eastward towards the Suwannee River during dry periods and flowed southeastward during wet periods, when water-table altitudes were higher (fig. 4). Vertical gradients at wells 2-7A and $2-7 \mathrm{~B}$, and at wells $2-8 \mathrm{~A}$ and $2-8 \mathrm{~B}$ indicated that flow in the vertical plane was downward along the western boundary of this farm. On the eastern side of dairy farm 2, vertical hydraulic gradients at wells 2-5A and $2-5 \mathrm{~B}$ varied from downward to upward, whereas vertical gradients at wells $2-6 \mathrm{~A}$ and $2-6 \mathrm{~B}$ indicated that flow in the vertical plane was upward. The lateral direction of ground-water flow beneath dairy farm 3 was northward, toward the Suwannee River (fig. 5). Vertical hydraulic gradients at wells 3-2A and 3-2B, and 3-7A and 3-7B indicated that the direction of ground-water flow in the vertical plane was downward. The lateral direction of ground-water flow beneath dairy farm 4 was southward during dry periods, and northward during wet periods, when water-table altitudes were higher (fig. 6). Vertical hydraulic gradients were periodically reversed at well pairs $4-4 A$ and $4-4 B, 4-5 A$ and $4-5 B, 4-7 A$ and $4-7 B$, and $4-8 \mathrm{~A}$ and $4-8 \mathrm{~B}$, indicating that the direction of ground-water flow in the vertical plane was variable in the upper $30 \mathrm{ft}$ of the Upper Floridan aquifer at dairy farm 4. 

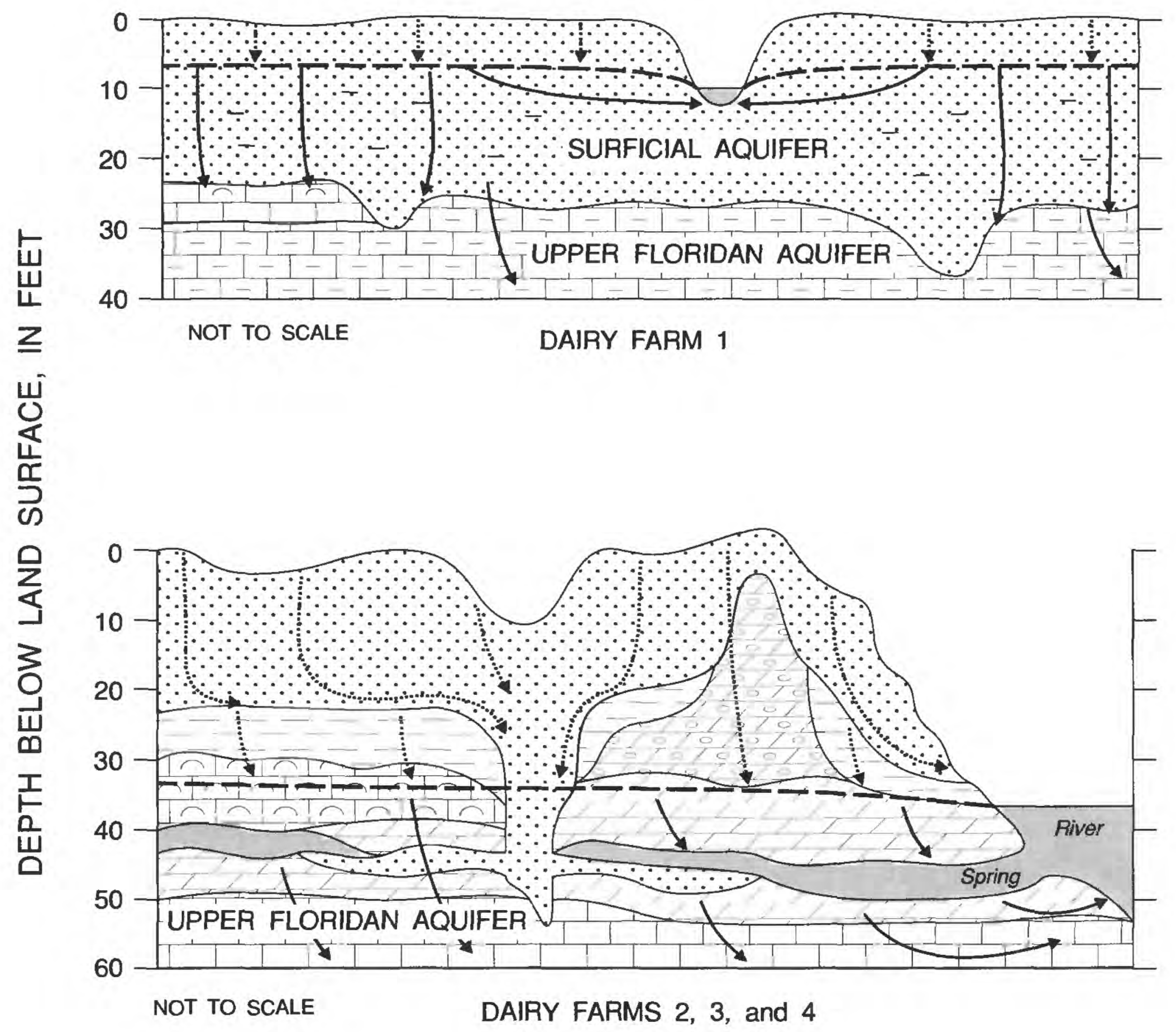

\section{EXPLANATION}

\begin{tabular}{|c|c|c|c|c|c|c|c|}
\hline$\because$ & Sand & $\begin{array}{|ll|}1 \\
1\end{array}$ & Limestone & \begin{tabular}{|l|l|}
-1 & -1 \\
-1 & -1 \\
-1 & -1 \\
\end{tabular} & $\begin{array}{l}\text { Micritic } \\
\text { limestone }\end{array}$ & $\begin{array}{l}0 / 9 \\
2 / 0 / 8 \\
\end{array}$ & $\begin{array}{l}\text { Cherty } \\
\text { dolomite }\end{array}$ \\
\hline$\because \because$ & Clayey sand & 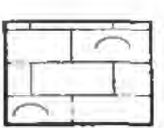 & $\begin{array}{l}\text { Biofragmental } \\
\text { limestone }\end{array}$ & 2,3 & Dolomite & & $\begin{array}{l}\text { Surface water or } \\
\text { water-filled caverns }\end{array}$ \\
\hline
\end{tabular}

Unsaturated zone flow

Saturated zone flow

- - Water table

Figure 2. Diagrammatic hydrogeologic sections of the monitored dairy farms in Lafayette and Suwannee Counties.

Three springs--Blue Spring, Telford Spring, and Convict Spring, which are in the area of North Florida where dairy farms were most numerous (fig. 1), were selected for water-quality monitoring. Water from the Suwannee River flowed into the vents of these springs for as much as six months of each year, when the level of the River was higher than the potentiometric elevation of the Upper Floridan aquifer. These springs were not sampled when they were submerged by the river. 

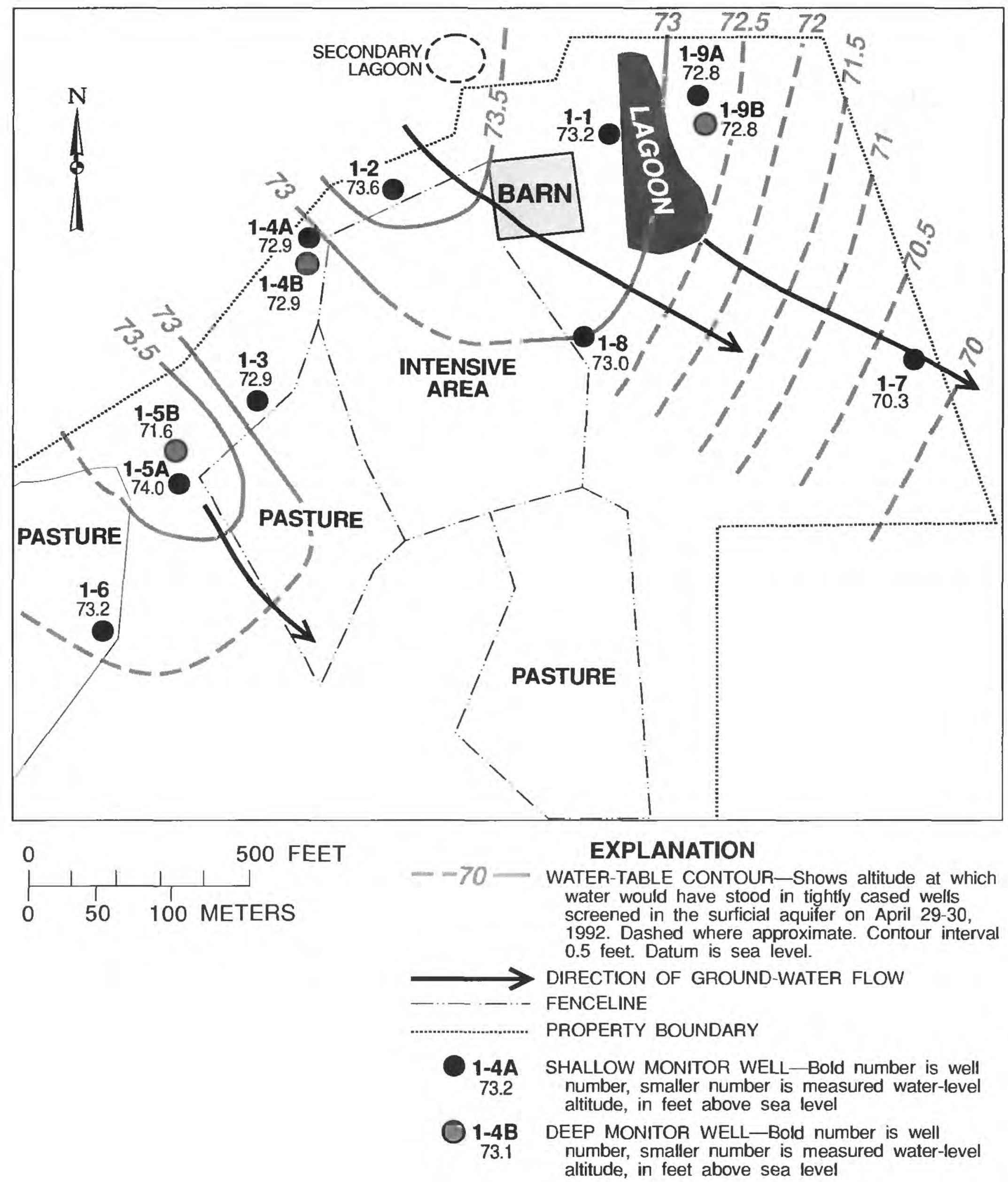

Figure 3. Location of monitoring wells, water-table altitudes and ground-water flow directions in the surficial aquifer on April 29-30, 1992, at dairy farm 1, Lafayette County.

\section{Dairy Farm Management Practices}

Dairy farm 1 is approximately one mile south of the city of Mayo, Fla. (fig. 1). This farm, which has been in operation since 1984, has a herd of about 300 dairy cows and a land area of 240 acres. From 1990 to mid-
1991, the dairy herd at this farm primarily grazed near the milking barn in an 80-acre pasture/intensive-use area (an area that was defoliated due to nearly constant livestock traffic and waste deposition). During that period, a portion of the dairy herd occasionally grazed in two adjacent 40-acre pastures (areas with low rates of 
livestock traffic and waste deposition and with abundant grasses). Since mid-1991, the herd at this farm was confined to the milking barn to a greater extent.

Wastewater from the milking barn flowed through a concrete culvert, installed in 1991, to an unlined lagoon of about 2 acres area. Wastewater was lost from the lagoon through evapotranspiration and perhaps by seepage to the surficial aquifer.

October 28-29, 1992

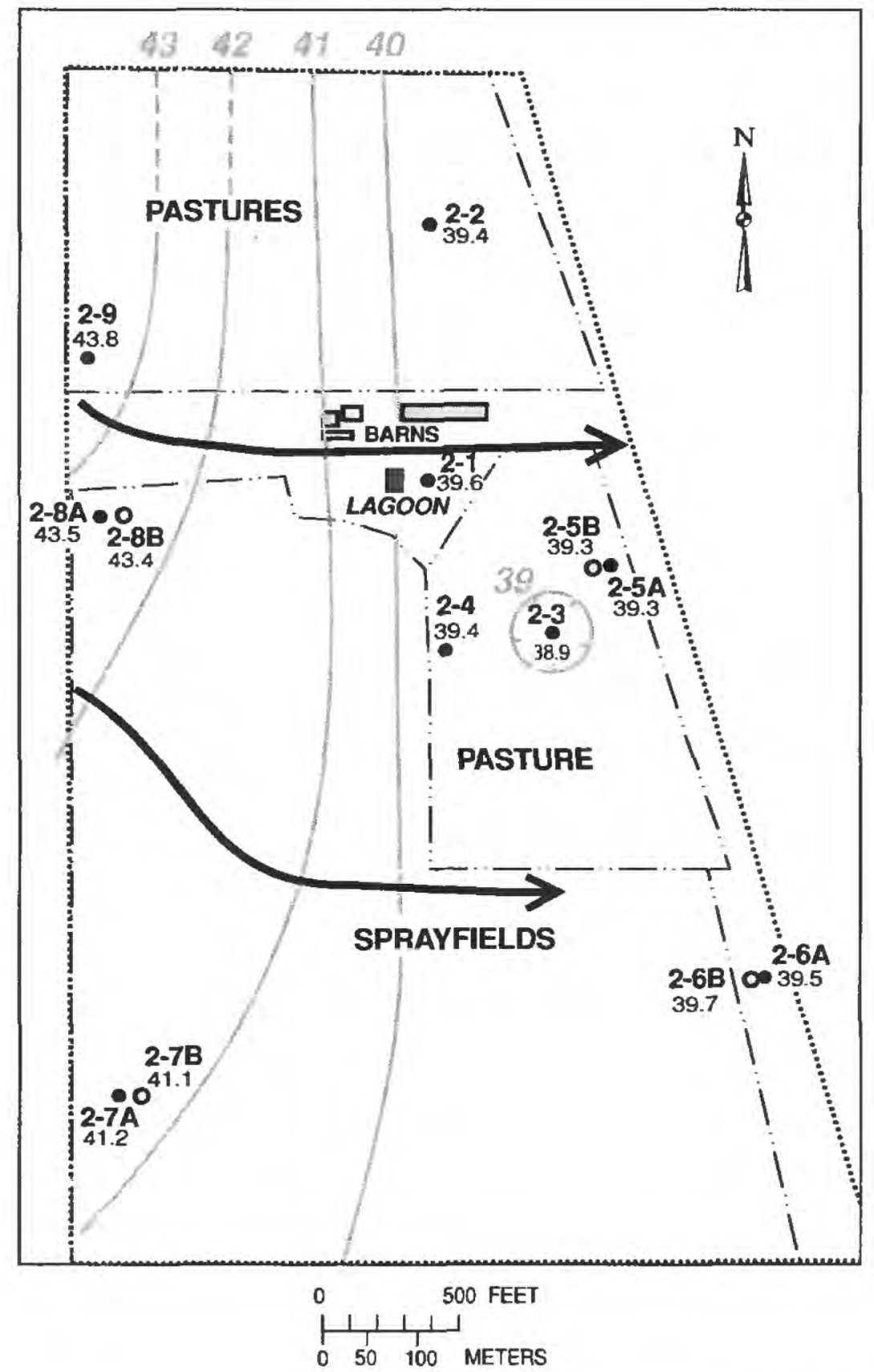

Dairy farm 2 is about five miles northwest of the city of Mayo in Lafayette County (fig. 1). This farm had the largest land area (700 acres) and the largest dairy herd (400 cows) and was also the oldest of the four dairy farms monitored for this study, having been in operation since 1952. In winter, the herd (fig. 4) at this farm grazed in pastures around the milking barn. During the summer, the dairy herd stayed primarily

January 28-29, 1993

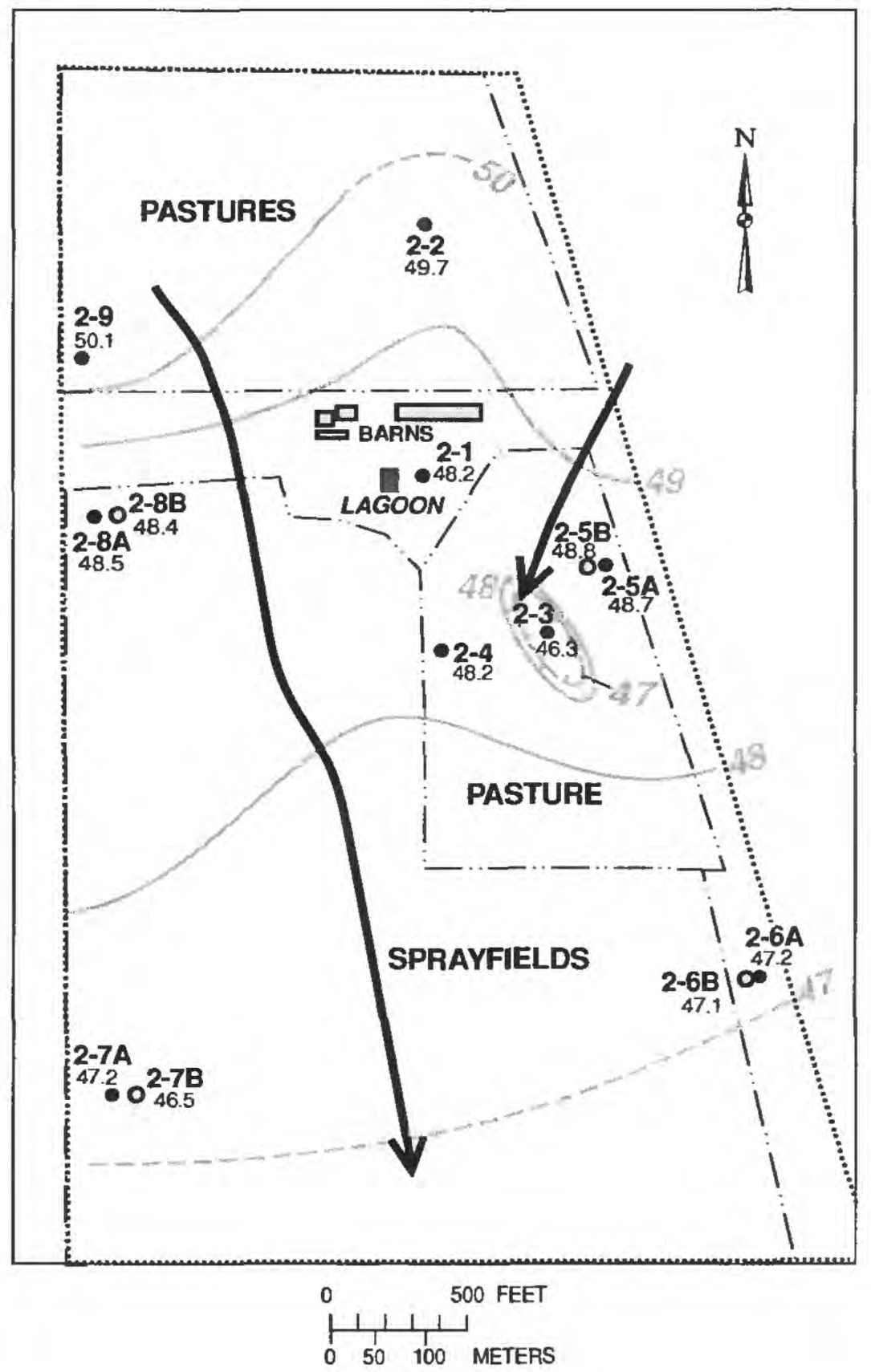

\section{EXPLANATION}

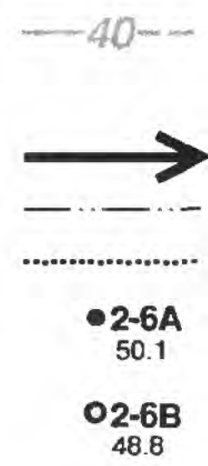

WATER-TABLE CONTOUR-Shows altitude at which water would have stood in in tightly cased wells screened in the Upper Floridan aquifer. Dashed where approximate. Contour interval 1 foot. Datum is sea level.

DIRECTION OF GROUND-WATER FLOW

FENCELINE

PROPERTY BOUNDARY

SHALLOW MONITOR WELL AND NUMBER-Bold number is well number, italic number is measured water-level altitude, in feet above sea level

DEEP MONITOR WELL AND NUMBER-Bold number is well number, italic number is measured water-level altitude, in feet above sea level

Figure 4. Location of monitoring wells, water-table altitudes and ground-water flow directions in the Upper Floridan aquifer on October 28-29, 1992, and January 28-29, 1993, at dairy farm 2, Lafayette County. 
near a cooling barn (where food, water, and cooling fans were available) next to the milking barn.

Wastewater from the barns flowed through pipes to a small unlined lagoon near the barns. Wastewater from this lagoon, along with ground water and synthetic fertilizers, were used to irrigate and fertilize corn (Zea mays) and other crops grown for silage on about 400 acres of land (designated on fig. 4 as spray fields).

Dairy farm 3 is about five miles northeast of the city of Mayo in Lafayette County (fig. 1). In operation since 1979 , this farm has a total land area of 80 acres and a herd of 175 dairy cows. A 10-acre intensive-use area, bordered by a 5-acre intensive pasture (marked by dense waste deposits and coarse grasses), is near the milking barn (fig. 5). Dry cows (cows that were not lactating) and cows expected to calve are kept in the 40-acre pasture on the south side of the farm. Near the milking barn, there is an unlined wastewater lagoon with an area of approximately 0.25 acres. Wastewater is lost from the lagoon through evaporation, overflow, and seepage into surficial sands.

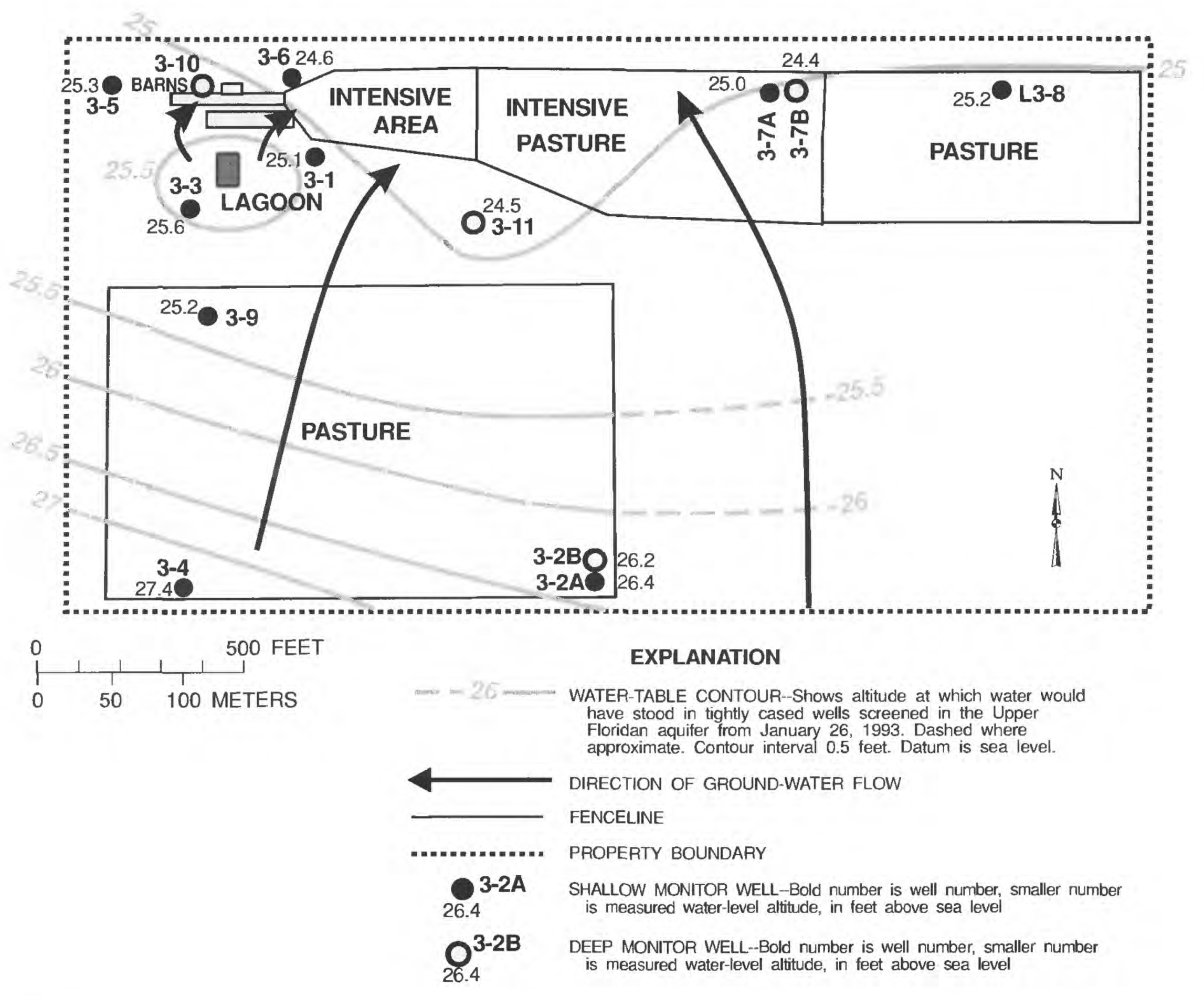

Figure 5. Location of monitoring wells, water-table altitudes and ground-water flow directions in the Upper Floridan aquifer on January 26-29, 1993, at dairy farm 3, Lafayette County. 
October 31, 1991
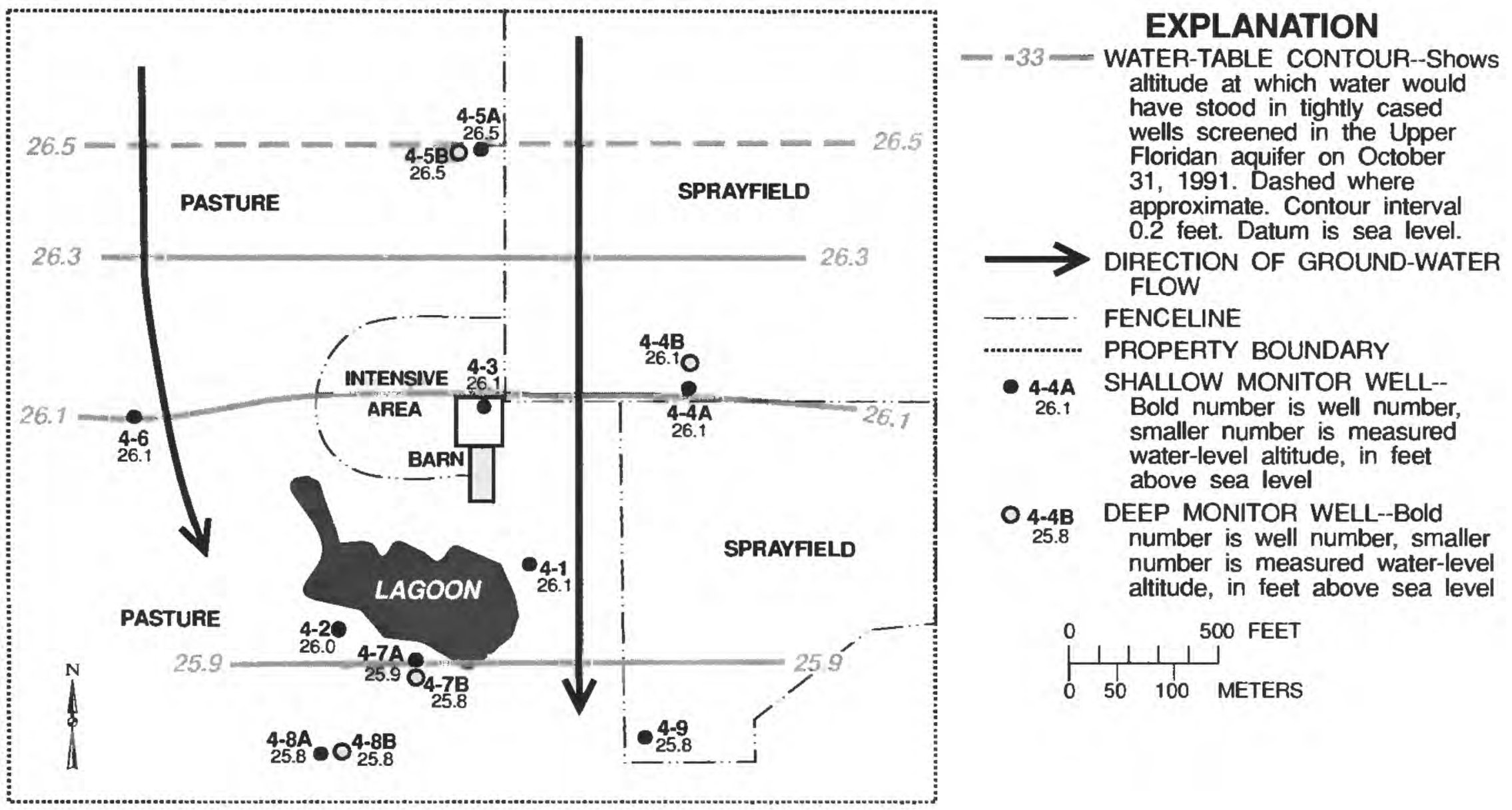

January 27, 1993

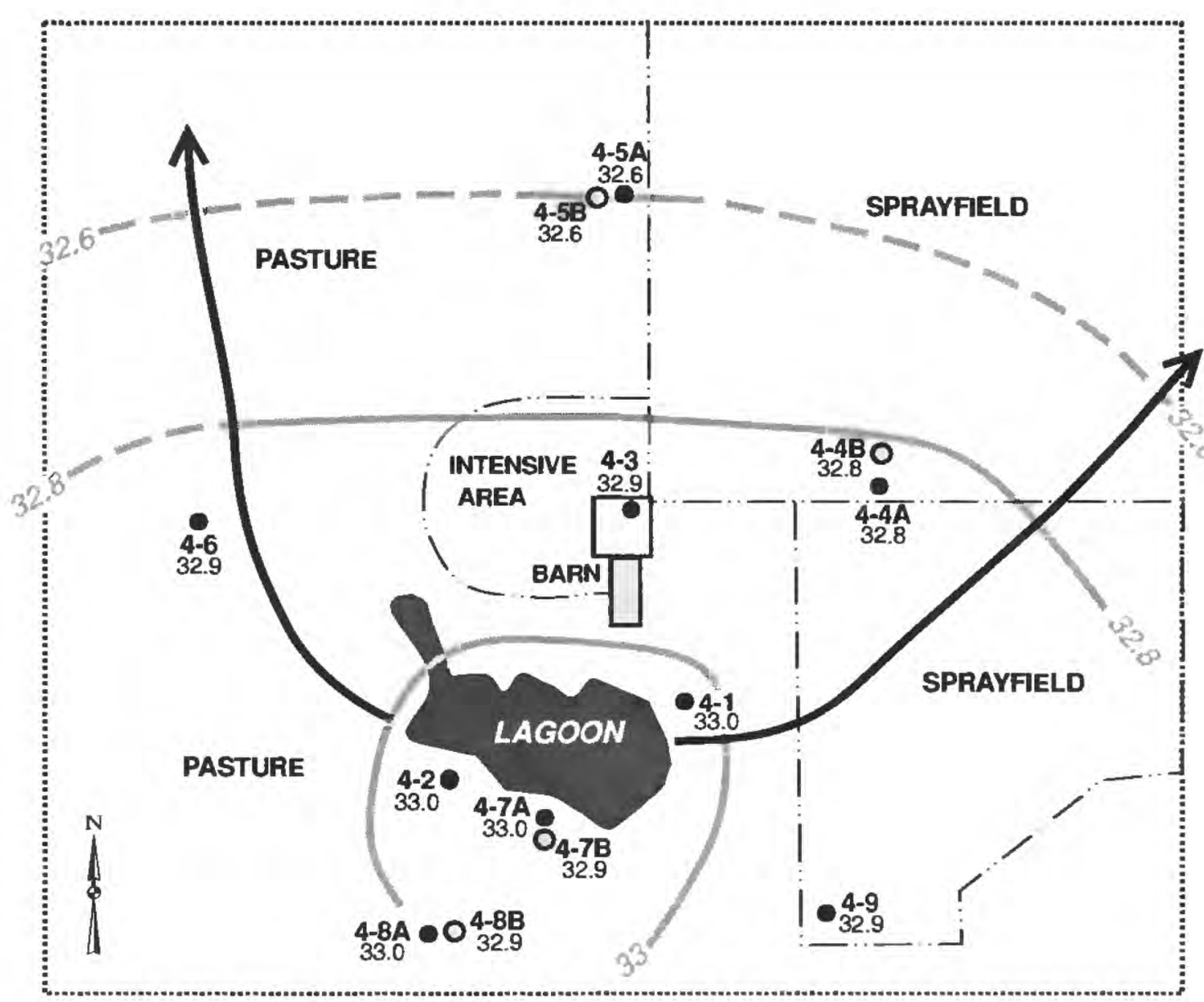

Figure 6. Monitoring wells, water-table altitudes and ground-water flow directions in the Upper Floridan aquifer on October 31, 1991, and January 27, 1992, at dairy farm 4, Suwannee County. 
Dairy farm 4 is about four miles northeast of Telford Spring in Suwannee County (fig. 1). In operation since 1980, this farm (fig. 6) has a herd of 550 dairy cows and an area of 470 acres. This farm has the largest wastewater lagoon (about 10 acres in surface area) of the farms investigated for this study. The cows at this farm graze in two 80 -acre pastures on the western side of the farm. The two 70-acre fields on the eastern side of the farm were wastewater spray fields, used for growing silage crop and for calve and heifer grazing. The northeastern spray field is usually planted in ryegrass (Lolium perenne), whereas the southeastern spray field is usually planted in millet (Pennisetum glaucum) or corn.

\section{METHODS OF STUDY}

This investigation consisted of three stages: selection of monitored dairy farms, selection of sampling locations, and water-quality sampling and analysis. These three topics are discussed in the following sections.

\section{Site Selection Procedure}

The four monitored dairy farms were chosen through a multi-stage selection process conducted in cooperation with FDEP. In 1989, officials from FDEP mailed a 3-page questionnaire to the owners of each dairy farm in North Florida. Questions pertained to the location, size, period of operation, herd size, feed stock, herd distribution, waste management practices, and crop-fertilization practices used at the farms. Several weeks later, interviewers from FDEP visited each of the farms and completed a 6-page follow-up dairy-farm evaluation form regarding topics on the questionnaire and topics such as land use, water use, and hydrogeologic features of the dairy farms. Representatives from FDEP, USGS, the U.S. Soil Conservation Service (SCS), and the University of Florida Agricultural Engineering Department (UF) met in early 1990 to discuss the results of the dairyfarm owner survey and the follow-up evaluation form and selected nine representative dairy farms for reconnaissance ground-water monitoring on the basis of information obtained from the surveys. Three to four monitoring wells were installed near land uses of interest at each of the nine dairy farms in early 1990 and these wells were periodically sampled for one year,
In early 1991, the USGS, in cooperation with FDEP, proposed to install additional wells at four of the nine monitored dairy farms to better determine the distribution of nitrate in ground water, and to analyze for additional constituents that would be useful in identifying the occurrence of denitrification in ground water. Representatives from FDEP, USGS, SCS, and UF met in early 1991 and, on the basis of the representative nature of farm management practices and of the hydrogeologic settings, selected the dairy farms discussed in this report for additional groundwater quality monitoring.

\section{Data Collection Network}

All of the monitoring wells drilled for this investigation are completed in the Upper Floridan aquifer, except for ten of the wells at dairy farm 1 . The 36 wells designated as shallow monitoring wells in this report were screened in the top ten feet of the saturated zone of the uppermost aquifer to allow evaluation of the quality of the shallowest ground water, which is most likely to be affected by overlying land uses. To investigate changes in ground-water quality with depth in the uppermost aquifers beneath these farms, 15 monitoring wells, referred to as deep monitoring wells in this report, were drilled $20 \mathrm{ft}$ deeper into the saturated zone than the shallow wells. Blue, Telford, and Convict Springs were selected for water-quality sampling because they are in the area where dairy farms are most numerous in North Florida (fig. 1).

At dairy farm 1, monitoring wells were drilled adjacent to the wastewater lagoon and the intensive-use area, and in the pasture on the western side of the farm (fig. 3). At dairy farm 2, pairs of shallow and deep wells were drilled along the upgradient and downgradient property boundaries, and several shallow wells were drilled in or adjacent to pastures, spray fields, and the wastewater lagoon (fig. 4). The monitoring wells at dairy farm 3 were principally arranged in east-west rows on the upgradient and downgradient property boundaries and near the wastewater lagoon and the intensive-use area (fig. 5). At dairy farm 4, monitoring wells were drilled near and downgradient from land use areas including: pastures, spray fields, intensive-use areas, and the wastewater lagoon (fig. 6). In addition to the 15-digit well identification number stored in the GWIS and WATSTORE databases of the USGS, each well drilled for this study was assigned a field identification number consisting of a one-digit farm 
number (from 1-4) followed by a well number determined by the order in which a well was drilled at each dairy farm. The field identification number of shallow wells in shallow/deep well pairs are assigned the suffix "A", whereas the deep wells in these well pairs are assigned the suffix " $B$ ". In this report, monitoring wells are referred to by their field identification numbers. The field-identification well numbers, depths of wells, land uses near wells, and aquifers in which monitoring wells were completed at the four farms are listed in table 1.
Monitoring wells were drilled using three methods for this study and for Andrews (1992): hollow-stem augering, air/foam rotary, and cable-tool. Monitoring wells screened in unconsolidated materials were drilled using hollow-stem augers. Most of the monitoring wells screened in consolidated material were drilled by the air/foam rotary method. Six monitoring wells at dairy farm 2 were drilled with cable-tool methods because sand-filled caverns penetrated by these wells made the use of rotarydrilling methods impossible.

Table 1. Characteristics of the dairy farm monitoring wells, Lafayette and Suwannee Counties, Florida

[Well designations A and B refer to shallow and deep wells, respectively, in a well pair, and the first digit of a well number corresponds to the farm number]

\begin{tabular}{|c|c|c|c|c|}
\hline $\begin{array}{c}\text { Well } \\
\text { number }\end{array}$ & $\begin{array}{l}\text { Depth } \\
\text { (in feet) }\end{array}$ & Depth type & Land use & $\begin{array}{c}\text { Aquifer in which } \\
\text { wells were com- } \\
\text { pleted }\end{array}$ \\
\hline $1-1^{*}$ & 25 & Shallow & Wastewater Lagoon & Surficial \\
\hline $1-2^{*}$ & 20 & Shallow & Intensive-use Area & Surficial \\
\hline $1-3^{*}$ & 15 & Shallow & Pasture & Surficial \\
\hline $1-4 A^{*}$ & 24 & Shallow & Intensive-use Area & Surficial \\
\hline $1-4 B$ & 48 & Deep & Intensive-use Area & Upper Floridan \\
\hline $1-5 A$ & 24 & Shallow & Pasture & Surficial \\
\hline $1-5 B$ & 47 & Deep & Pasture & Upper Floridan \\
\hline $1-6$ & 19 & Shallow & Pasture & Surficial \\
\hline $1-7$ & 19 & Shallow & Wastewater Lagoon & Surficial \\
\hline $1-8$ & 24 & Shallow & Intensive-use Area & Surficial \\
\hline $1-9 \mathrm{~A}$ & 19 & Shallow & Wastewater Lagoon & Surficial \\
\hline $1-9 B$ & 37 & Deep & Wastewater Lagoon & Surficial \\
\hline $2-1^{*}$ & 48 & Shallow & Wastewater Lagoon & Upper Floridan \\
\hline $2-2 *$ & 48 & Shallow & Pasture & Upper Floridan \\
\hline $2-3 *$ & 46 & Shallow & Pasture & Upper Floridan \\
\hline $2-4^{*}$ & 48 & Shallow & Pasture & Upper Floridan \\
\hline $2-5 A$ & 49 & Shallow & Pasture & Upper Floridan \\
\hline $2-5 B$ & 70 & Deep & Pasture & Upper Floridan \\
\hline $2-6 \mathrm{~A}$ & 47 & Shallow & Spray Field & Upper Floridan \\
\hline $2-6 B$ & 69 & Deep & Spray Field & Upper Floridan \\
\hline $2-7 \mathrm{~A}$ & 60 & Shallow & Spray Field & Upper Floridan \\
\hline $2-7 \mathrm{~B}$ & 80 & Deep & Spray Field & Upper Floridan \\
\hline $2-8 \mathrm{~A}$ & 60 & Shallow & Spray Field & Upper Floridan \\
\hline $2-8 B$ & 79 & Deep & Spray Field & Upper Floridan \\
\hline $2-9$ & 73 & Deep & Pasture & Upper Floridan \\
\hline $3-1 *$ & 44 & Shallow & Intensive-use Area & Upper Floridan \\
\hline $3-2 A^{*}$ & 45 & Shallow & Pasture & Upper Floridan \\
\hline $3-2 B$ & 66 & Deep & Pasture & Upper Floridan \\
\hline $3-3 *$ & 39 & Shallow & Wastewater Lagoon & Upper Floridan \\
\hline $3-4^{*}$ & 48 & Shallow & Pasture & Upper Floridan \\
\hline $3-5$ & 49 & Shallow & Hay Storage & Upper Floridan \\
\hline
\end{tabular}


Table 1. Characteristics of the dairy farm monitoring wells, Lafayette and Suwannee Counties, Florida--Continued

\begin{tabular}{|c|c|c|c|c|}
\hline $\begin{array}{c}\text { Well } \\
\text { number }\end{array}$ & $\begin{array}{c}\text { Depth } \\
\text { (in feet) }\end{array}$ & Depth type & Land use & $\begin{array}{c}\text { Aquifer in which } \\
\text { wells were com- } \\
\text { pleted }\end{array}$ \\
\hline $3-6$ & 59 & Shallow & Intensive-use Area & Upper Floridan \\
\hline $3-7 \mathrm{~A}$ & 43 & Shallow & Pasture & Upper Floridan \\
\hline $3-7 \mathrm{~B}$ & 74 & Deep & Pasture & Upper Floridan \\
\hline $3-8$ & 56 & Shallow & Pasture & Upper Floridan \\
\hline 3.9 & 47 & Shallow & Pasture & Upper Floridan \\
\hline $3-10$ & 79 & Deep & Barn & Upper Floridan \\
\hline 3-11 & 76 & Deep & Pasture & Upper Floridan \\
\hline $4-1 *$ & 40 & Shallow & Wastewater Lagoon & Upper Floridan \\
\hline $4-2 *$ & 35 & Shallow & Wastewater Lagoon & Upper Floridan \\
\hline $4-3 *$ & 50 & Shallow & Intensive-use Area & Upper Floridan \\
\hline $4-4 A^{*}$ & 43 & Shallow & Wastewater Spray Field & Upper Floridan \\
\hline 4-4B & 72 & Deep & Wastewater Spray Field & Upper Floridan \\
\hline $4-5 \mathrm{~A}$ & 56 & Shallow & Pasture & Upper Floridan \\
\hline $4-5 B$ & 73 & Deep & Pasture & Upper Floridan \\
\hline $4-6$ & 49 & Shallow & Pasture & Upper Floridan \\
\hline $4-7 \mathrm{~A}$ & 44 & Shallow & Wastewater Lagoon & Upper Floridan \\
\hline $4-7 \mathrm{~B}$ & 63 & Deep & Wastewater Lagoon & Upper Floridan \\
\hline $4-8 \mathrm{~A}$ & 51 & Shallow & Wastewater Lagoon & Upper Floridan \\
\hline $4-8 B$ & 66 & Deep & Wastewater Lagoon & Upper Floridan \\
\hline $4-9$ & 41 & Deep & Wastewater Spray Field & Upper Floridan \\
\hline
\end{tabular}

${ }^{*}$ Well drilled in 1990 for Andrews (1992)

Several diameters of casing and two types of materials were used to case the 51 monitoring wells sampled for this study. Fifteen of the 51 monitoring wells were drilled by the USGS in 1989-90. These wells were cased with 2-inch diameter, schedule 80 PVC casing with $10-\mathrm{ft}$ screens. The remaining 36 monitoring wells, which were drilled by a commercial driller during 1990-91, were cased primarily with 4 -inch-diameter, schedule $40 \mathrm{PVC}$ casing and $10 \mathrm{ft}$ screens, except for the 6 wells drilled at dairy farm 2 using the cable-tool method (wells 2-6B, 2-7 A, 2-7B, 2-8A, 2-8B, and 2-9) which have 6-inch- and 8-inch-diameter steel casings. Two of the wells (2-6B and 2-7B) drilled using the cable-tool method were not screened, whereas the other 4 wells drilled with this method (2-7A, 2-8A and B, and 2-9) have 4-inch diameter PVC internal casings. The boreholes around each of the well screens were packed with washed quartz sand or gravel, and the sand or gravel was capped by a 2-ft thick layer of bentonite pellets. Above the bentonite, annular spaces were filled with neat portland type I cement.
Well-development methods used prior to water-quality sampling were chosen based upon well-casing diameters. The 2-inch-diameter monitoring wells were developed using compressed air and bailers, whereas the monitoring wells with larger-diameter casings were developed using submersible pumps.

\section{Collection and Analysis of Water Samples}

Water samples for this study were collected quarterly from the 51 dairy farm monitoring wells and the three springs between May 1991 and January 1993. Seven of these wells (1-4A, 1-4B, 2-6A, 2-6B, 3-6, 4-4A, and 4-4B) and Convict Spring were sampled monthly from May 1991 to March 1993. Samples from these wells were analyzed for temperature, $\mathrm{pH}$, specific conductance, and concentrations of dissolved nitrate, nitrite nitrogen, ammonia nitrogen, ammonia plus organic nitrogen, chloride, inorganic carbon, oxygen, and biochemical oxygen demand (spring water only). Water samples were also collected from selected wells for analysis of 
counts of denitrifying bacteria. Water-quality data collected from March 1990 to February 1991 from wells at these four farms (Andrews, 1992) are also included in statistical summaries of water-quality data in this report.

Water samples were collected from monitoring wells after temperature and dissolved oxygen concentrations had stabilized, typically after at least three standing well-casing volumes of water had been purged from each well. Stainless steel and teflon submersible pumps or PVC bailers were used to purge wells prior to sampling and for collecting water samples. Temperature, $\mathrm{pH}$, specific conductance, and dissolved oxygen concentrations of water samples were measured in the field. Water samples to be analyzed at the laboratory were filtered in the field through 0.45 -micron pore-size polycarbonate filters and were stored on ice in polyethylene bottles prior to shipment to the USGS laboratory. Nutrient samples were collected and stored in $125 \mathrm{~mL}$ bottles and were preserved with $0.5 \mathrm{~mL}$ of mercuric chloride/sodium chloride solution. Dissolved inorganic carbon samples were collected in the field in polypropylene and silicone syringes and filtered into $100 \mathrm{~mL}$ glass bottles through 0.45 micron pore-size silver filters in stainless steel and teflon filter holders. Spring-water samples to be analyzed for biochemical oxygen demand were not filtered in the field. Bacteria sampling tubes were inoculated in the field and counted at the office.

Data collected during this study were collected using standard methods routinely used by the USGS in studies of this nature, as described by Wood (1976), and Fishman and Friedman (1989). Groundwater levels and spring discharges were measured using methods and equipment described by U.S. Geological Survey (1977) and Rantz and others (1982). Counts of bacteria in water samples collected from selected wells were made using the mostprobable-number method (Britton and Greeson, 1987 , p. 67-72).

To determine sources of nitrate in ground water, water samples from wells 1-1, 1-4A, 1-4B, 2-4, 2-6A, 2-6B, 3-3, 4-4A, and 4-4B were analyzed for nitrogen isotope ratios at the Wetlands Soils Research Laboratory at the University of Florida at Gainesville, Fla., in July 1991. These samples were analyzed using standard reduction methods, zeolite sorption and combustion, and mass spectrometry
(Hauck, 1982; Burke and others, 1990). In May 1993, water samples from the Blue, Telford, and Convict Springs were collected and sent to a commercial laboratory for nitrogen isotope analysis using methods outlined by Vogel (1961).

To determine the factors affecting denitrification, two water samples collected from well 2-6A and one water sample collected from well 1-4A were stored in a 5-gallon glass reaction vessel (sealed and shielded against contact with oxygen and light) and were analyzed periodically for nitrate and nitrite concentrations for as long as 14 days after sample collection. The reaction vessel was pressurized with argon gas to replace the water removed for analysis and to prevent inflow of atmospheric oxygen. Several days after the water samples were collected in April and July, 1992, the samples were dosed with $5 \mathrm{~mL}$ of saturated glucose solution to determine if denitrification was limited by a lack of carbon substrate.

\section{NITRATE CONCENTRATIONS IN GROUND WATER}

Potential sources of nitrate in ground water in North Florida include soil nitrogen, plant debris, animal wastes, and synthetic fertilizers. Organic forms of nitrogen in soils, plant debris, and animal wastes are converted to nitrate through the bacterially-mediated processes of ammonification and nitrification. Nitrification, the process by which bacteria produce nitrate from ammonia $\left(\mathrm{NH}_{4}{ }^{+}\right)$, contributes nitrate to ground water near sources of organic nitrogen. Nitrate can be removed from ground water through the bacterially-mediated process of denitrification. Andrews (1992) provides a more complete discussion of the nitrogen cycle as it relates to ground water.

In this report, concentrations of nitrate in ground water exceeding the median concentrations in water from background network wells are referred to as elevated. In Lafayette and Suwannee Counties, median background nitrate concentrations were $0.22 \mathrm{mg} / \mathrm{L}$ and $0.23 \mathrm{mg} / \mathrm{L}$ for the surficial and Upper Floridan aquifers, respectively (Florida Department of Environmental Protection, written commun., 1986). 


\section{Dairy Farm 1}

Nitrate concentrations in water samples from the nine shallow and the three deep monitoring wells at dairy farm 1 are described in the following two sections. Because synthetic fertilizers were not applied at dairy farm 1 or to adjoining properties, elevated

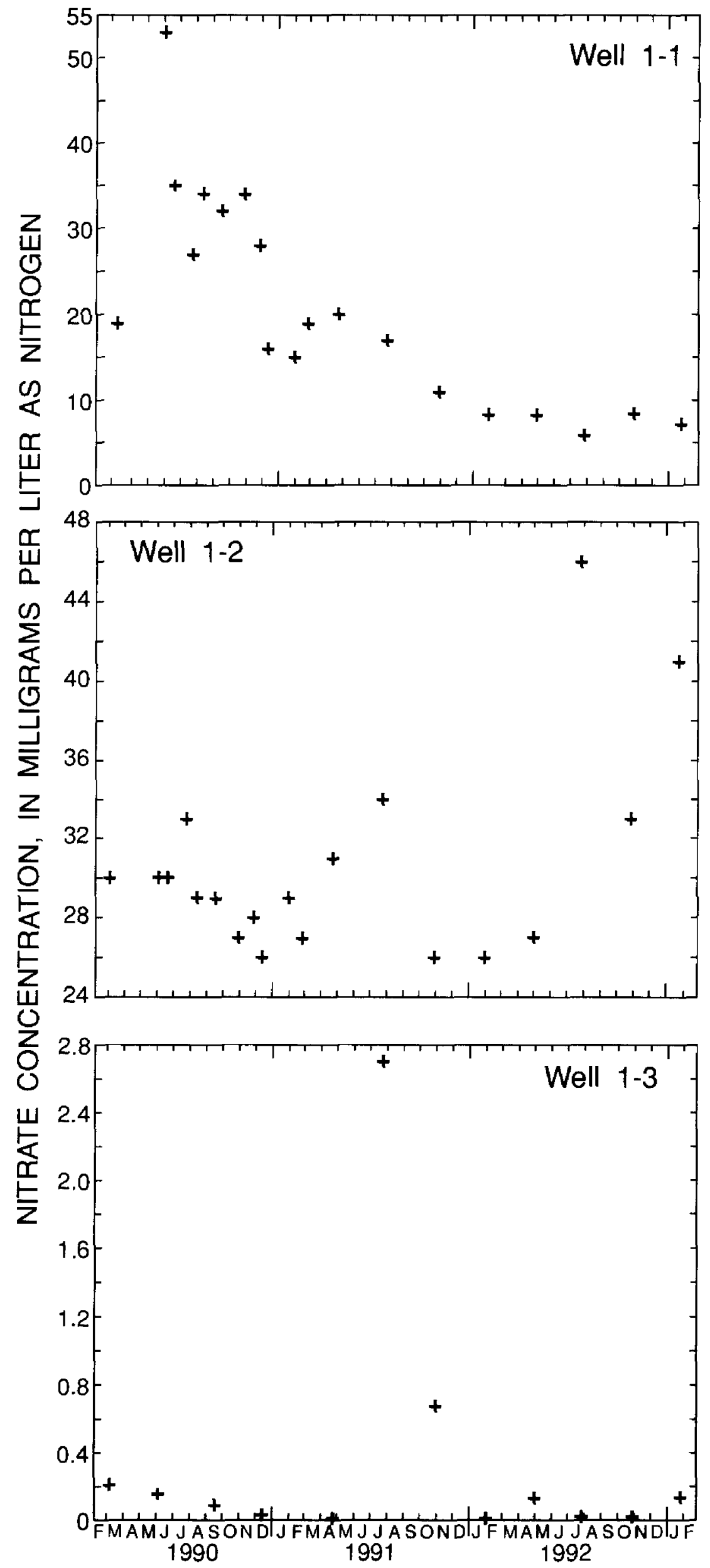

concentrations of nitrate in ground water beneath this farm (figs. 7,8 ) probably were caused by leachate from livestock wastes or soils. This farm was the only one of the four monitored dairy farms with a surficial aquifer as the uppermost aquifer, so the chemical quality of ground water sampled at this farm was somewhat different than that at the other farms.
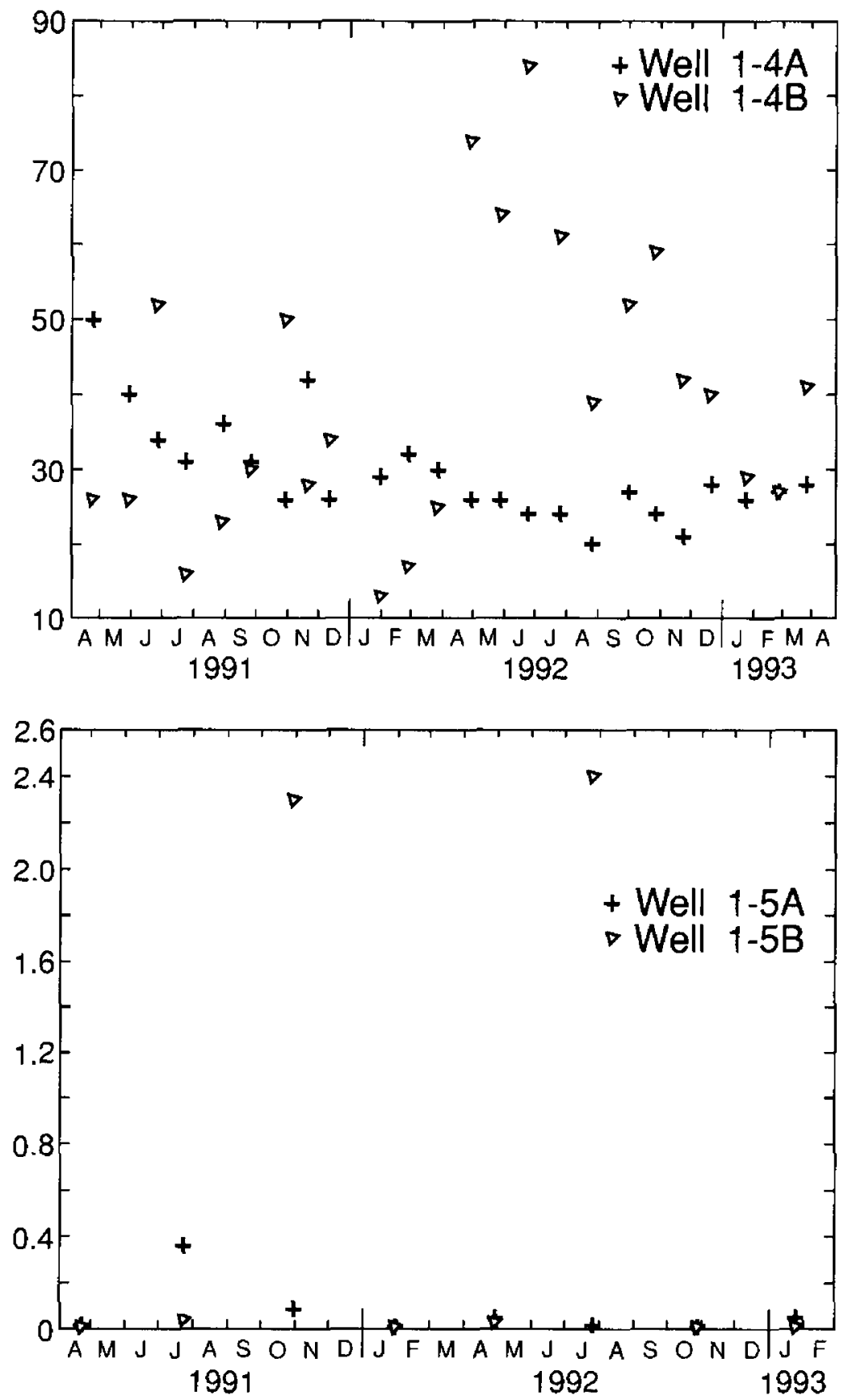

Figure 7. Nitrate concentrations in water from wells at dairy farm 1 in Lafayette County, 1990-93. 

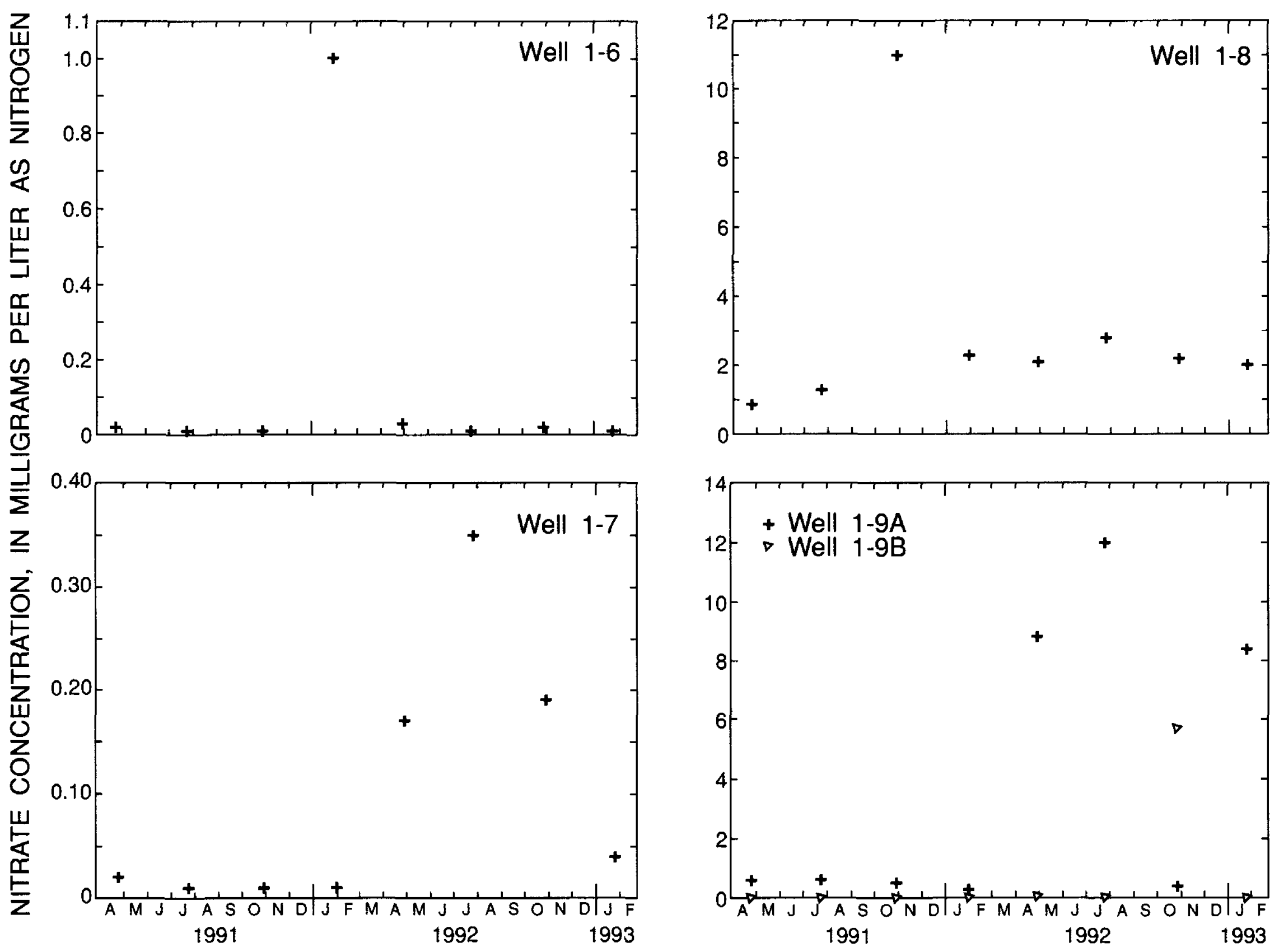

Figure 8. Nitrate concentrations in water from wells at dairy farm 1 in Lafayette County, 1991-93.

\section{Water from Shallow Wells}

Water from a shallow well near the wastewater lagoon (well 1-1) and from the shallow wells near the intensive-use area (wells 1-2, 1-4A) at dairy farm 1 had median concentrations of nitrate that were substantially higher than the $0.22 \mathrm{mg} / \mathrm{L}$ median concentration from the FDEP background wells completed in the surficial aquifer in the study area (table 2). Nitrate concentrations in water from well 1-1 decreased from 53 to $7.3 \mathrm{mg} / \mathrm{L}$ from 1990-93 (fig. 7), coincident with the replacement of the nearby conduit to the lagoon in early 1991 . The decrease in nitrate concentrations in water samples from this well after the replacement of the conduit to the wastewater lagoon indicates that the old conduit may have been leaking wastewater in the vicinity of this well. Water from well 1-2, which is next to the intensive-use area (fig. 2), had the highest median concentration of nitrate $(29 \mathrm{mg} / \mathrm{L})$ of water from the shallow wells at this farm. Nitrate concentrations in water from this well were generally less than $35 \mathrm{mg} / \mathrm{L}$, although a sample collected in July, 1992 had a nitrate concentration of $46 \mathrm{mg} / \mathrm{L}$ (fig. 7). Nitrate concentrations in water from well 1-4A decreased from 40 to $28 \mathrm{mg} / \mathrm{L}$ during 1990-93 (fig. 7), perhaps due to lower rates of waste deposition near this well caused by greater confinement of the dairy herd starting in early 1991 . Water from well $1-8$, which is downgradient from the barn and from the intensiveuse area (fig. 3), had a median nitrate concentration of $2.2 \mathrm{mg} / \mathrm{L}$, and one water sample from this well exceeded the drinking water standard for nitrate (fig. 8). Water from well 1-9A, which was about $30 \mathrm{ft}$ east of the wastewater lagoon (fig. 3), had nitrate concentrations ranging from $0.29-12 \mathrm{mg} / \mathrm{L}$ (fig. 8), which indicates that leaching of nitrogen-rich wastewater from the lagoon periodically affected the quality of shallow ground water near this well. 
Table 2. Median values of selected water-quality characteristics in water from shallow monitoring wells at dairy farm 1, Lafayette County, Florida, 1990-93

[All values in $\mathrm{mg} / \mathrm{L}$ (milligrams per liter) unless stated otherwise; ${ }^{\circ} \mathrm{C}$, degrees Celsius; $\mu \mathrm{S} / \mathrm{cm}$, microsiemens per centimeter at $25{ }^{\circ} \mathrm{C} ; 1,000 \mathrm{col} / 100 \mathrm{ml}$, thousand colonies per 100 milliliters; --, no data collected; <, less than; all water-quality characteristics except temperature, $\mathrm{pH}$, specific conductance, and denitrifying bacteria are dissolved (filtered) values]

\begin{tabular}{|c|c|c|c|c|c|c|c|c|c|}
\hline \multirow{2}{*}{ Water-quality characteristic } & \multicolumn{9}{|c|}{ Median value for water samples from indicated well } \\
\hline & $1-1$ & $1-2$ & $1-3$ & $1-4 A$ & $1-5 \mathrm{~A}$ & $1-6$ & $1-7$ & $1-8$ & $1-9 A$ \\
\hline Temperature $\left({ }^{\circ} \mathrm{C}\right)$ & 23.0 & 22.5 & 22.5 & 22.5 & 23.5 & 22.5 & 22.5 & 23.0 & 23.0 \\
\hline $\mathrm{pH}$ (pH units) & 4.9 & 5.7 & 6.0 & 4.6 & 5.7 & 5.1 & 5.5 & 5.2 & 5.4 \\
\hline $\begin{array}{l}\text { Specific conductance } \\
(\mu \mathrm{S} / \mathrm{cm})\end{array}$ & 170 & 710 & 260 & 530 & 190 & 44 & 54 & 70 & 220 \\
\hline Nitrate $e^{1,2}$ & 8.4 & 29 & .08 & 27 & .04 & $<.02$ & .03 & 2.2 & .60 \\
\hline Nitrite nitrogen ${ }^{2}$ & $<.01$ & .02 & .01 & .01 & $<.01$ & $<.01$ & $<.01$ & $<.01$ & .01 \\
\hline Kjeldahl nitrogen ${ }^{2}$ & 2.2 & .72 & .37 & .73 & .74 & .57 & .41 & .28 & .42 \\
\hline Ammonia nitrogen ${ }^{2}$ & 1.9 & .05 & .05 & .26 & .28 & .11 & .12 & .01 & .06 \\
\hline Phosphorus $^{2}$ & $<.02$ & $<.02$ & .03 & $<.02$ & $<.02$ & .02 & .02 & $<.02$ & $<.02$ \\
\hline Chloride & 20 & 74 & 60 & 46 & 28 & 4.8 & 7.2 & 8.8 & 43 \\
\hline Oxygen & 1.5 & 1.1 & 6 & 1.9 & 1.4 & .3 & 1.5 & 2.1 & 1.6 \\
\hline Inorganic carbon & 3.6 & 14 & 13 & 4.6 & 12 & 5.0 & 6.4 & 3.4 & 14 \\
\hline $\begin{array}{l}\text { Denitrifying bacteria } \\
(1,000 \mathrm{col} / 100 \mathrm{ml})^{3}\end{array}$ & $>240$ & $>24$ & -- & 110 & 130 & $>24$ & 175 & 2 & 24 \\
\hline
\end{tabular}

\footnotetext{
${ }^{1}$ Nitrite plus nitrate nitrogen.

${ }^{2}$ Values below detection limits are calculated as $1 / 2$ of the detection limit, unless otherwise noted.

${ }^{3}$ Values above the dilution detection limits are calculated using those limits.
}

Water from shallow wells over 100 meters from the wastewater lagoon or upgradient from the lagoon and the intensive-use area at this farm (wells 1-3, 1-5A, 1-6, 1-7) had lower nitrate concentrations, many of which were near the median concentration from background wells. Water from well 1-3, which is on the northern edge of the intensive-use area at this farm (fig. 3), had a median nitrate concentration of $0.08 \mathrm{mg} / \mathrm{L}$, with the highest nitrate concentration of $2.7 \mathrm{mg} / \mathrm{L}$ occurring in a water sample collected from this well in July 1991 (fig. 7). All of the nitrate concentrations in water samples from well 1-5A, which is between the two western pastures at this farm (fig. 3), were below $0.4 \mathrm{mg} / \mathrm{L}$ (fig. 7). Water from wells 1-6 and 1-7 had median nitrate concentrations near background levels (fig. 8), although a sample collected from well 1-6 in January 1992 had a nitrate concentration of $1.0 \mathrm{mg} / \mathrm{L}$. The relatively low nitrate concentrations in water from these wells indicate that the quality of shallow ground water in the vicinity of these wells was virtually unaffected by leachate from livestock wastes.

\section{Water from Deep Wells}

With the exception of well 1-4B, nitrate concentrations in water samples from the deep wells at this farm were generally lower than those in adjacent shallow wells. Water from well 1-4B, completed in the Upper Floridan aquifer immediately west of the intensive-use area at dairy farm 1 (fig. 3), had the highest median concentration of nitrate $(36 \mathrm{mg} / \mathrm{L})$ of the deep monitoring wells at this farm (table 3 ) and generally had higher nitrate concentrations than water from the adjacent shallow well (1-4A, fig. 7). The quality of deeper ground water in the vicinity of this well probably was affected by livestock waste leachate from the neighboring intensive-use area and may also have been affected by leachate from the wastewater lagoon, which may be upgradient from this well. Although there were not enough wells completed in the Upper Floridan aquifer at this farm to determine ground-water flow directions in that aquifer at this farm, water-table altitudes in the deeper well 1-9B were generally higher than those measured in wells $1-4 \mathrm{~B}$ and 1-5B (app. I), indicating that deeper groundwater may have flowed from the wastewater lagoon 
toward wells 1-4B and 1-5B. Two water samples from well $1-5 B$ had nitrate concentrations exceeding $2 \mathrm{mg} / \mathrm{L}$ (fig. 7), indicating that the quality of deeper ground water in the vicinity of this well was periodically affected by leachate from livestock wastes. Except for those two water samples, nitrate concentrations in water from well $1-5 B$ were generally less than or equal to those in water from the neighboring shallow well, 1-5A (fig. 7). The median concentration of nitrate in water from well $1-9 \mathrm{~B}(<0.02 \mathrm{mg} / \mathrm{L})$, was the lowest of water from the deep monitoring wells at this farm (table 3), but one water sample collected from this well in October 1992 had a nitrate concentration exceeding $5 \mathrm{mg} / \mathrm{L}$ (fig. 8), indicating that the quality of deeper ground water in the vicinity of this well was periodically affected by leachate from livestock wastes. Except for that one sample, water from well 1-9B had lower concentrations of nitrate than water from the adjacent shallower well (1-9A, fig. 8), indicating that deeper ground water was less affected by leachate from the adjacent wastewater lagoon than shallow ground water in the vicinity of those wells.

Table 3. Median values of selected water-quality characteristics in water from deep monitoring wells at dairy farm 1, Lafayette County, Florida, 1990-93

[All values in $\mathrm{mg} / \mathrm{L}$ (milligrams per liter) unless stated otherwise; ${ }^{\circ} \mathrm{C}$, degrees Celsius; $\mu \mathrm{S} / \mathrm{cm}=$ microsiemens per centimeter at $25^{\circ} \mathrm{C} ; 1,000$ $\mathrm{col} / 100 \mathrm{ml}$, thousand colonies per 100 milliliters; --, no data collected; <, less than, all water-quality characteristics except for temperature, $\mathrm{pH}$, specific conductance, and denitrifying bacteria are dissolved (filtered) samples]

\begin{tabular}{|c|c|c|c|}
\hline \multirow[t]{2}{*}{ Water-quality characteristic } & \multicolumn{3}{|c|}{$\begin{array}{l}\text { Median value for water sam- } \\
\text { ples from indicated well }\end{array}$} \\
\hline & $1-4 B$ & $1-5 B$ & $1-9 B$ \\
\hline Temperature $\left({ }^{\circ} \mathrm{C}\right)$ & 22.5 & 22.5 & 23.0 \\
\hline $\mathrm{pH}$ (pH units) & 7.1 & 7.1 & 5.2 \\
\hline $\begin{array}{l}\text { Specific conductance } \\
(\mu \mathrm{S} / \mathrm{cm})\end{array}$ & 1,100 & 490 & 60 \\
\hline Nitrate $^{1,2}$ & 36 & .02 & $<.02$ \\
\hline Nitrite nitrogen ${ }^{2}$ & .02 & $<.01$ & $<.01$ \\
\hline Kjeldahl nitrogen ${ }^{2}$ & .46 & .52 & .32 \\
\hline Ammonia nitrogen ${ }^{2}$ & .04 & .28 & .04 \\
\hline Phosphorus $^{2}$ & .02 & .04 & $<.02$ \\
\hline Chloride & 110 & 18 & 6.4 \\
\hline Oxygen & .2 & .3 & 2.4 \\
\hline Inorganic carbon & 48 & 54 & 6.6 \\
\hline $\begin{array}{r}\text { Denitrifying bacteria } \\
(1,000 \mathrm{col} / 100 \mathrm{ml})^{3}\end{array}$ & 11 & -- & 24 \\
\hline
\end{tabular}

\footnotetext{
${ }^{1}$ Nitrite plus nitrate nitrogen.

${ }^{2}$ Values below detection limits are calculated as $1 / 2$ of the detection limit, unless otherwise noted.

${ }^{2}$ Values above dilution detection limits are calculated using those limits
}

Values of $\mathrm{pH}$ and dissolved inorganic carbon were higher in water from wells $1-4 B$ and $1-5 B$ than in water from well $1-9 \mathrm{~B}$ or the shallow wells completed in the sandy surficial aquifer at this farm because wells 1-4B and 1-5B were completed in the carbonate Upper Floridan aquifer (tables 2, 3). Higher $\mathrm{pH}$ values and dissolved inorganic carbon concentrations in water from these wells were due to limestone dissolution in the Upper Floridan aquifer, which can be expressed by the following reaction equation:

$\mathrm{CaCO}_{3}+\mathrm{H}_{2} \mathrm{CO}_{3}$ (carbonic acid from rainwater and overlying soils) ---> $\mathrm{Ca}^{+2}+2 \mathrm{HCO}_{3}{ }^{-}$.

The bicarbonate ion $\left(\mathrm{HCO}_{3}{ }^{-}\right)$, which comprises most of the dissolved inorganic carbon at the $\mathrm{pH}$ range of water in this aquifer (Morel and Hering, 1993), buffers ground water to near-neutral $\mathrm{pH}$ 's. Ground water in the surficial aquifer, which is not comprised of limestone, was more acidic and had lower dissolved inorganic carbon concentrations (tables 2,3) than ground water in the Upper Floridan aquifer.

\section{Dairy Farm 2}

Nitrate concentrations in water samples from the eight shallow wells and the five deep monitoring wells, all of which were completed in the karstic Upper Floridan aquifer, at dairy farm 2 (figs. 9-11) are described in the following two sections. Nitrate in ground water at this farm may have been derived from leachate from the unlined wastewater lagoon, livestock wastes deposited on pastures, soils, or wastewater and synthetic nitrogen fertilizers applied to crops grown on spray fields.

\section{Water from Shallow Wells}

Median concentrations of nitrate are higher than the median nitrate concentration in the background monitoring network in water from all but one (well 2$8 \mathrm{~A}$ ) of the eight shallow monitoring wells at dairy farm 2 (table 4). At this farm, the highest nitrate concentrations were detected primarily in water from shallow wells downgradient from the wastewater lagoon and the wastewater spray fields. Water from well $2-1$, which is near the wastewater lagoon (fig. 4), had the highest median nitrate concentration $(50 \mathrm{mg} / \mathrm{L})$ of water samples from the shallow monitoring wells at this farm (table 4). Seasonal changes in ground-water flow directions between wet (higher water-table altitude) and dry (lower water-table altitude) seasons caused significant changes in nitrate concentrations in water 
from well 2-1. Concentrations of nitrate in water from this well were greater than $50 \mathrm{mg} / \mathrm{L}$ during dry periods, when the well was downgradient from the wastewater lagoon, but were less than $15 \mathrm{mg} / \mathrm{L}$ during wet periods when the well was not downgradient from the lagoon (figs. 4, 9, 10). Water from well 2-2, which is in a
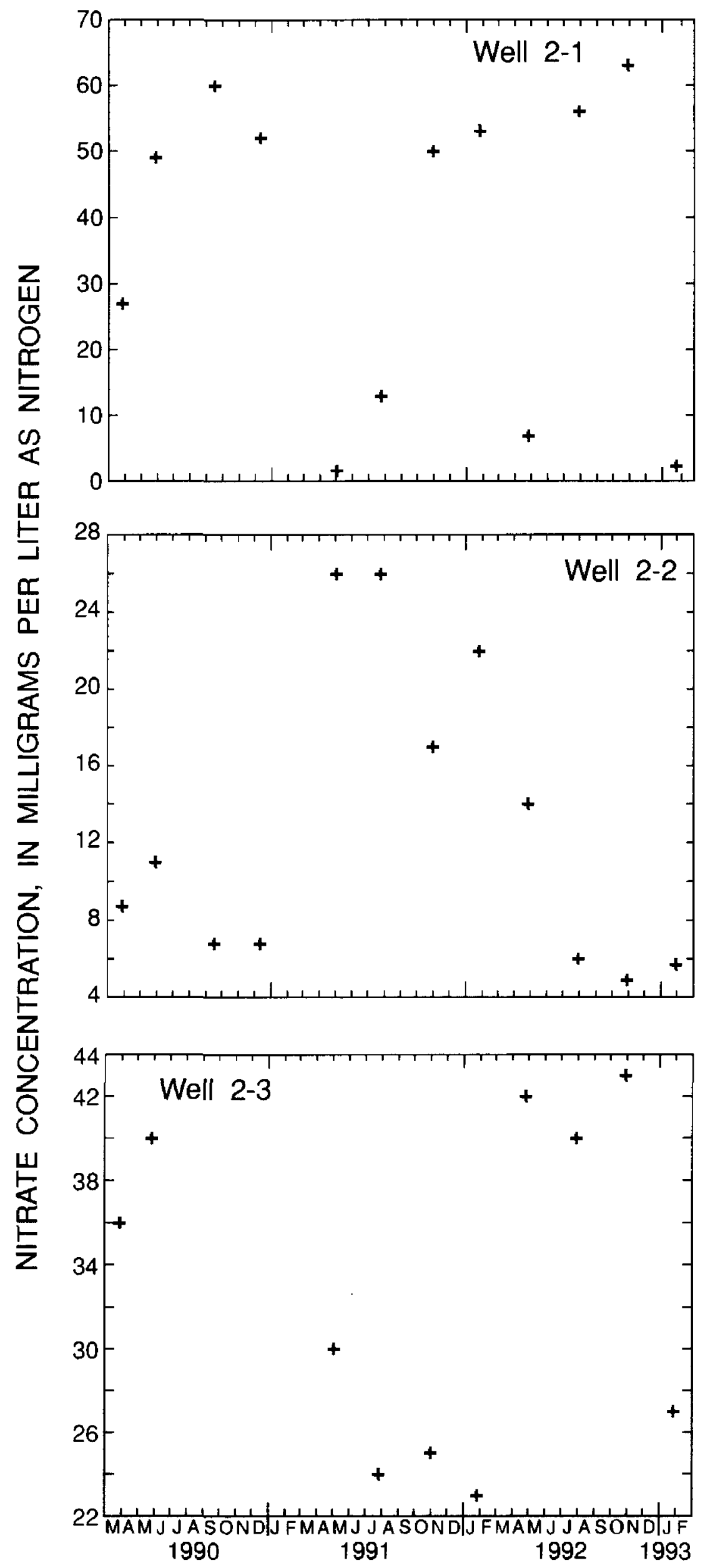

pasture (fig. 4), had an elevated median nitrate concentration $(9.8 \mathrm{mg} / \mathrm{L})$. Nitrate concentrations in water from this well ranged up to $26 \mathrm{mg} / \mathrm{L}$ in mid-1991 (fig. 9), indicating that leachate from livestock wastes deposited on the pasture was affecting the quality of shallow ground water in the vicinity of this well.

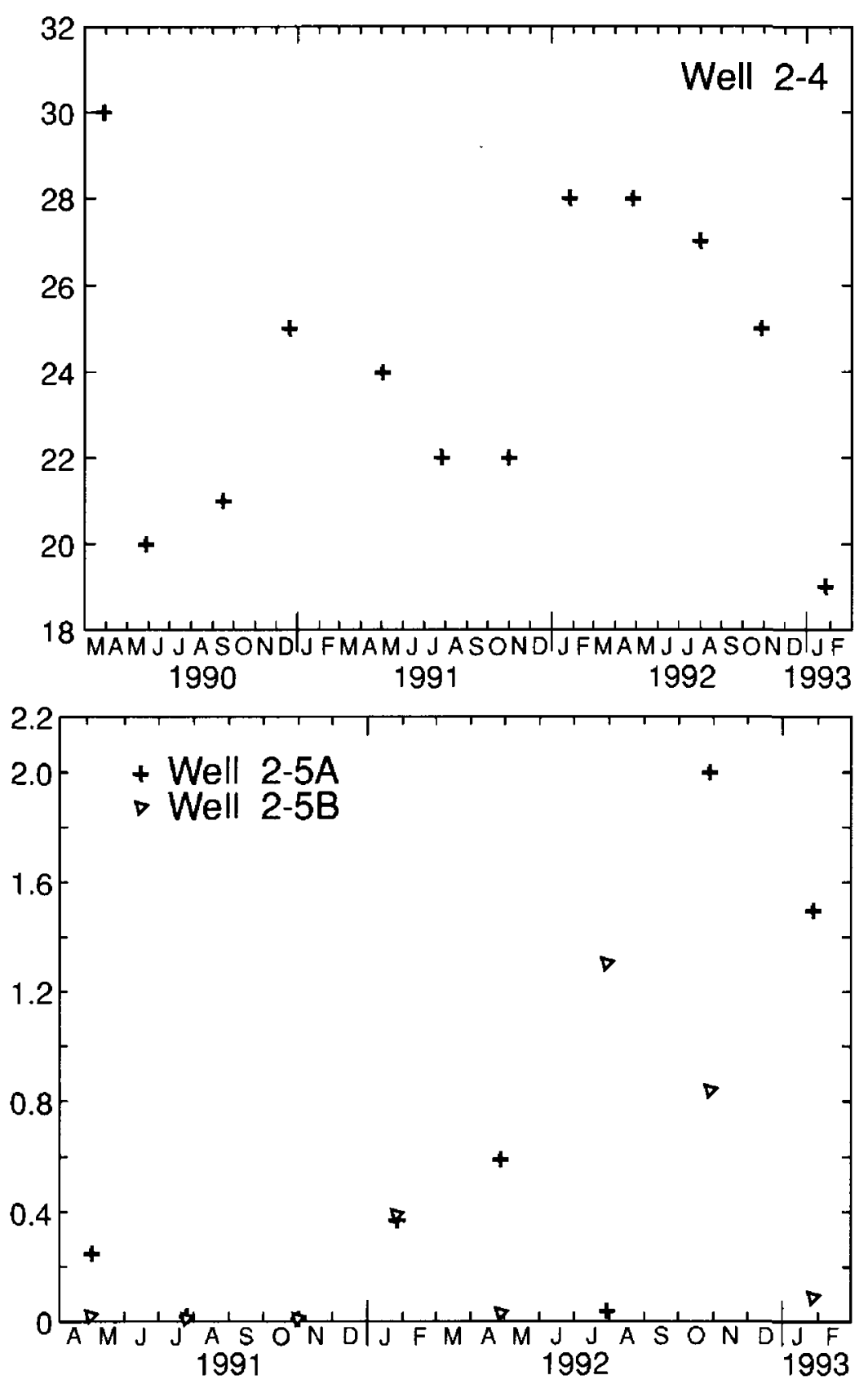

Figure 9. Nitrate concentrations in water from wells at dairy farm 2 in Lafayette County, 1990-93. 


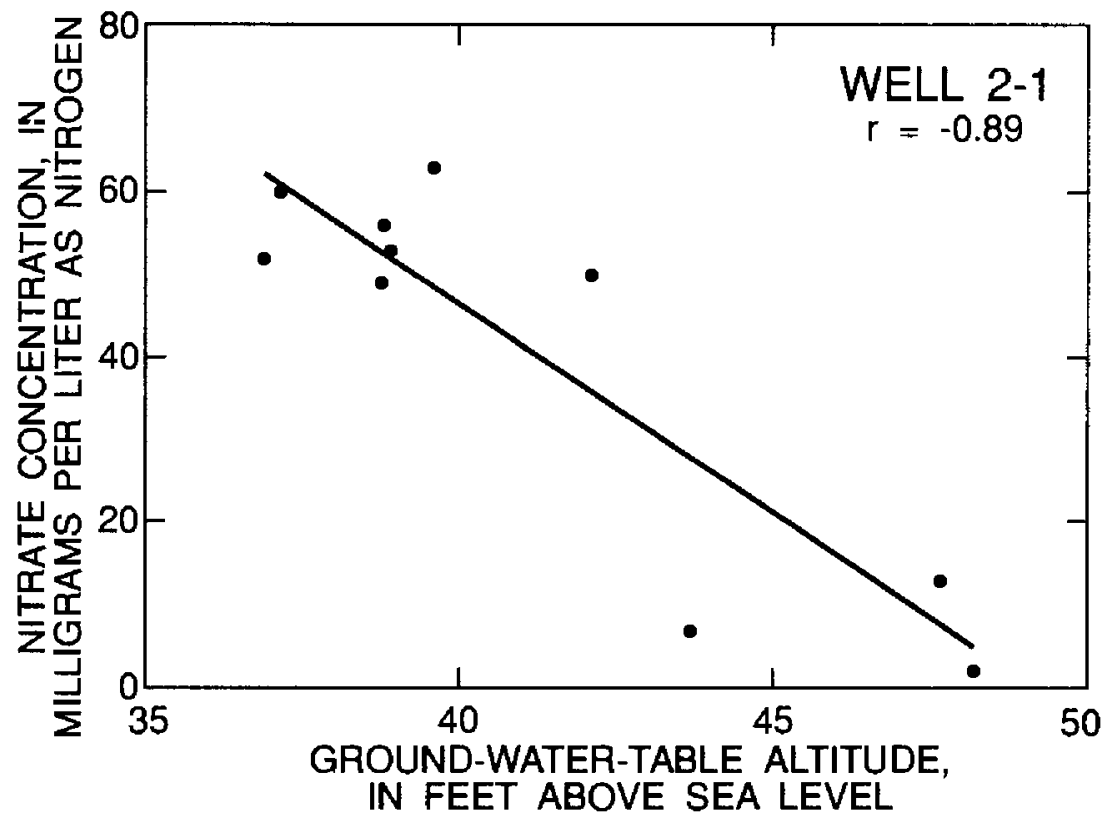

Figure 10. Relation between water-level altitude and nitrate concentration in water from well 2-1 in Lafayette County, 1990-93.

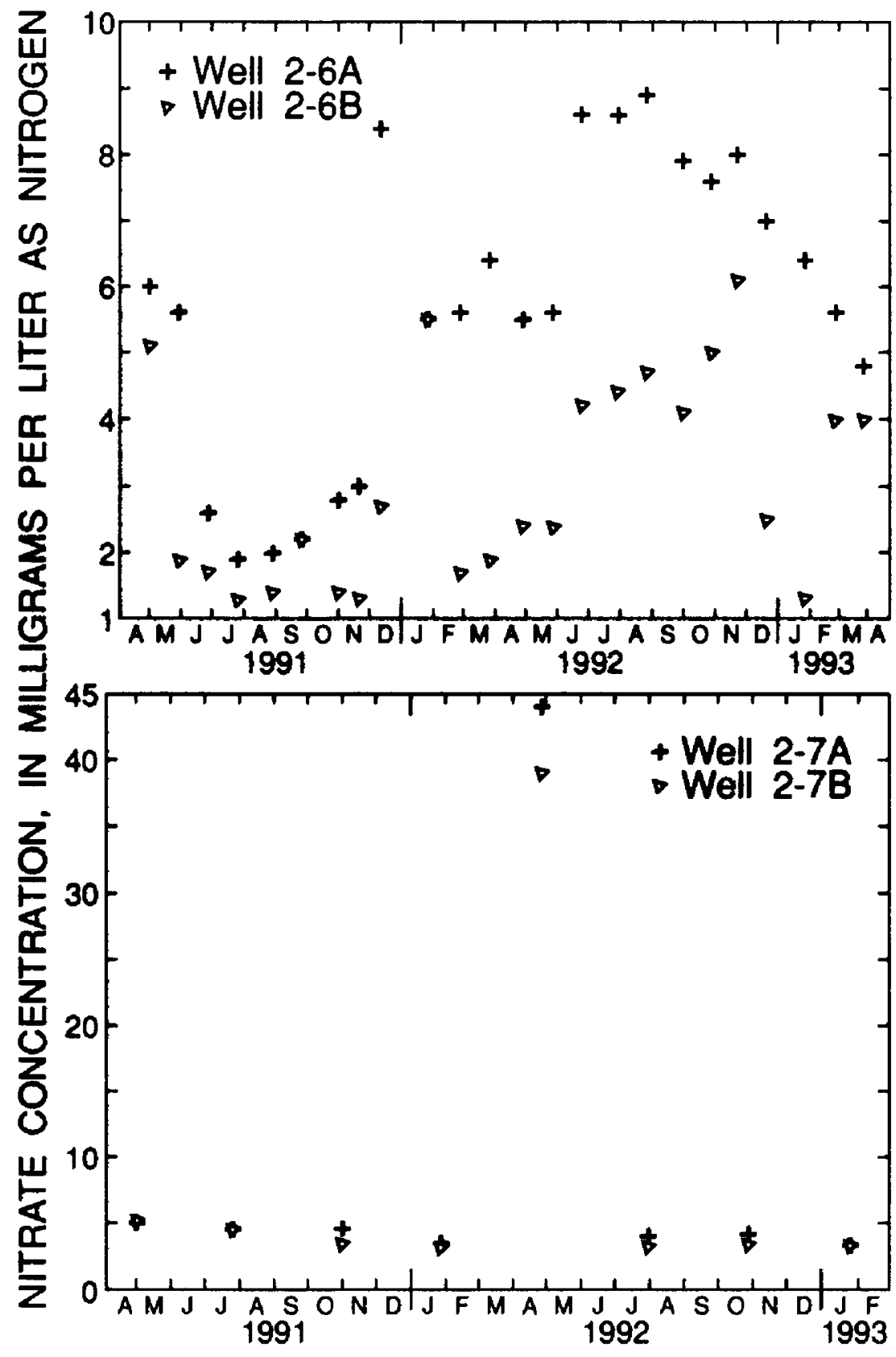

Water from wells 2-3 and 2-4 had nitrate concentrations ranging up to 43 and $28 \mathrm{mg} / \mathrm{L}$ (fig. 9), respectively, indicating that leachate from livestock wastes or from synthetic fertilizers applied to the spray field upgradient from both of these wells (fig. 4) had affected the quality of shallow ground water in the vicinity of these wells.

Nitrate concentrations were generally much lower in water samples from shallow wells which are upgradient or more than $300 \mathrm{ft}$ from the wastewater lagoon and the spray fields at dairy farm 2 . Nitrate concentrations in water from well 2-5A, which is on the eastern boundary of the intensive pasture at this farm (fig. 4) ranged from less than $0.02-2.0 \mathrm{mg} / \mathrm{L}$ (fig. 9), indicating that the quality of shallow ground water near this well was only slightly affected by leachate from livestock wastes.
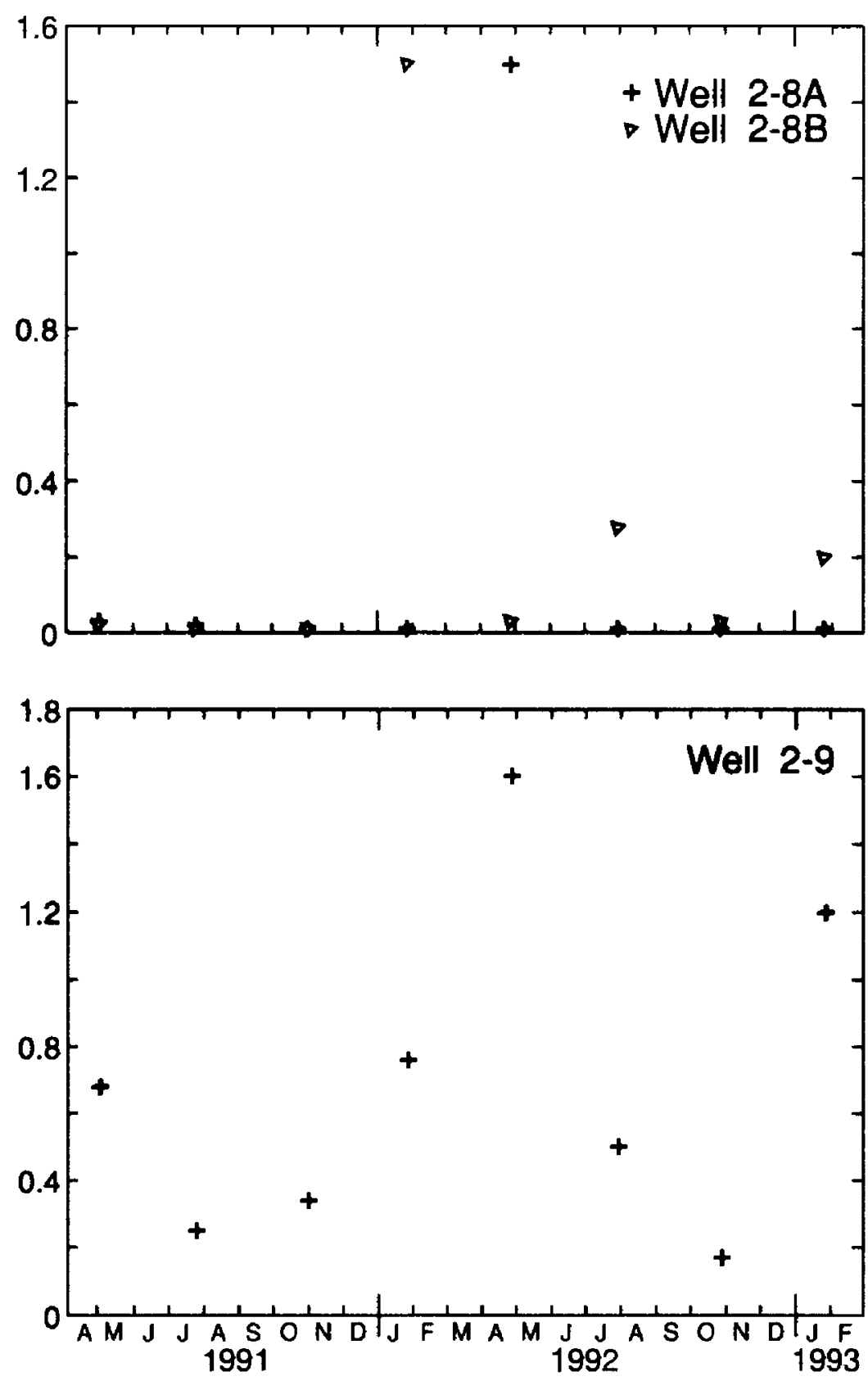

Figure 11. Nitrate concentrations in water from wells at dairy farm 2 in Lafayette County, 1990-93. 
Table 4. Median values of selected water-quality characteristics in water from shallow monitoring wells at dairy farm 2 , Lafayette County, Florida, 1990-93

[All values in $\mathrm{mg} / \mathrm{L}$ (milligrams per liter) unless stated otherwise; ${ }^{\circ} \mathrm{C}$, degrees Celsius; $\mu \mathrm{S} / \mathrm{cm}$, microsiemens per centimeter at $25^{\circ} \mathrm{C} ; 1,000 \mathrm{col} / 100 \mathrm{ml}$, thousand colonies per 100 milliliters; --, no data collected; <, less than; all water-quality characteristics except temperature, $\mathrm{pH}$, specific conductance, and denitrifying bacteria are dissolved (filtered) samples]

\begin{tabular}{|c|c|c|c|c|c|c|c|c|}
\hline \multirow{2}{*}{$\begin{array}{l}\text { Water-quality } \\
\text { characteristic }\end{array}$} & \multicolumn{8}{|c|}{ Well Number } \\
\hline & $2-1$ & $2-2$ & $2-3$ & $2-4$ & $2-5 A$ & $2-6 A$ & $2-7 \mathrm{~A}$ & $2-8 \mathrm{~A}$ \\
\hline Temperature $\left({ }^{\circ} \mathrm{C}\right)$ & 22.5 & 21.5 & 22.5 & 22.5 & 22.0 & 22.5 & 22.5 & 23.0 \\
\hline $\mathrm{pH}$ (pH units) & 6.9 & 7.2 & 7.2 & 7.2 & 7.4 & 7.6 & 7.6 & 7.5 \\
\hline $\begin{array}{l}\text { Specific conductance } \\
\qquad(\mu \mathrm{S} / \mathrm{cm})\end{array}$ & 1,200 & 630 & 790 & 680 & 580 & 410 & 370 & 410 \\
\hline Nitrate $^{1,2}$ & 50 & 9.8 & 33 & 24 & .31 & 5.6 & 4.6 & $<.02$ \\
\hline Nitrite nitrogen $^{2}$ & .02 & .01 & .01 & .01 & .04 & $<.01$ & $<.01$ & $<.01$ \\
\hline Kjeldahl nitrogen ${ }^{2}$ & .35 & .30 & .48 & .30 & .28 & .20 & $<20$ & $<.20$ \\
\hline Ammonia nitrogen ${ }^{2}$ & .02 & .01 & .04 & .01 & .11 & .01 & .01 & .01 \\
\hline Phosphorus $^{2}$ & .10 & .09 & .15 & .11 & .04 & .05 & .04 & .02 \\
\hline Chloride & 20 & 14 & 16 & 16 & 6.6 & 7.0 & 6.0 & 6.0 \\
\hline Oxygen & 2.2 & 1.6 & 4.6 & 5.4 & 1.2 & 2.5 & 5.7 & .6 \\
\hline Inorganic carbon & 71 & 52 & 45 & 32 & 52 & 41 & 39 & 35 \\
\hline $\begin{array}{l}\text { Denitrifying bacteria } \\
(1,000 \mathrm{col} / 100 \mathrm{ml})^{3}\end{array}$ & -- & 67 & $\cdot--$ & -- & 46 & 15 & -- & -- \\
\hline
\end{tabular}

\footnotetext{
${ }^{1}$ Nitrite plus nitrate nitrogen.

${ }^{2}$ Values below detection limits are calculated as $1 / 2$ of the detection limit, unless otherwise noted.

${ }^{3}$ Values above the dilution detection limits are calculated using those limits.
}

Nitrate concentrations in water from well 2-6A, which is downgradient from the spray fields and the eastern pasture at this farm (fig. 4), decreased from about 6 $\mathrm{mg} / \mathrm{L}$ in early 1991 to less than $3 \mathrm{mg} / \mathrm{L}$ in late-1991 and subsequently increased to $8-9 \mathrm{mg} / \mathrm{L}$ in 1992 (fig. 11), possibly due to seasonal variations of fertilization and cropping of the upgradient spray fields. Nitrate concentrations in water from well 2-7A generally ranged from $3-5 \mathrm{mg} / \mathrm{L}$, although a water sample taken from that well in April 1992 had a nitrate concentration of $44 \mathrm{mg} / \mathrm{L}$ (fig. 11), indicating that the quality of shallow ground water in the vicinity of this well was affected to a variable extent by leachate from the surrounding spray field or other upgradient sources. Water from well 2-8A, also on the upgradient western boundary of this farm (fig. 4), had the lowest median nitrate concentration of the shallow wells at this farm (less than $0.02 \mathrm{mg} / \mathrm{L}$ ). The low concentrations of nitrate in water samples from this well (fig. 11) indicate that shallow ground water near this well was not affected by leachate from livestock wastes or fertilizers.

\section{Water from Deep Wells}

Water from the five deep monitoring wells at dairy farm 2 which are along the upgradient (western) boundary (wells 2-7B, 2-8B, and 2-9) and along the downgradient (eastern) boundary (wells $2-5 \mathrm{~B}$ and $2-6 B$ ) of this farm, generally had lower concentrations of nitrate than water from the adjacent shallow wells (tables 4,5 ), indicating that the quality of deeper ground water beneath this farm was less affected by leachate from livestock wastes or synthetic fertilizers than shallow ground water. Water samples collected from well 2-7B had the highest median concentration of nitrate $(3.3 \mathrm{mg} / \mathrm{L})$ of the deeper wells at this farm (table 5), indicating that deeper ground water in the vicinity of this well was affected by leachate from livestock wastes or fertilizers applied to the surrounding spray field or to upgradient farms. Nitrate concentrations in water from this well were generally near $5 \mathrm{mg} / \mathrm{L}$, except for a sample collected in April 1992, which contained $39 \mathrm{mg} / \mathrm{L}$ of nitrate (fig. 11). The similarities between nitrate concentrations in water from well 2-7B to those in water from the 
adjacent shallow well, 2-7A (fig. 11), suggest that water sampled from these wells was recharged from the same land-use area or that these wells were completed in the same conduit system in the karstic Upper Floridan aquifer. Water from well 2-6B had a median nitrate concentration of $2.4 \mathrm{mg} / \mathrm{L}$, and nitrate concentrations as high as $6.2 \mathrm{mg} / \mathrm{L}$ were detected in water from this well (fig. 11), indicating that the quality of deeper ground water in the vicinity of this well was affected by leachate from wastewater or synthetic fertilizers applied to upgradient spray fields. The relatively low median nitrate concentrations in water from wells $2-5 \mathrm{~B}, 2-8 \mathrm{~B}$ and $2-9,(0.06,0.03$ and $0.59 \mathrm{mg} / \mathrm{L}$, respectively), and the highest nitrate concentrations in water from these wells $(1.3-1.5 \mathrm{mg} / \mathrm{L}$, figs. 9,11 ) indicate that the quality of deeper ground water in the vicinity of these wells was only slightly affected by leachate from livestock wastes or synthetic fertilizers.

Table 5. Median values of selected water-quality characteristics in water from deep monitoring wells at dairy farm 2, Lafayette County, Florida, 1990-93

[All values in $\mathrm{mg} / \mathrm{L}$ (milligrams per liter) unless stated otherwise; ${ }^{\circ} \mathrm{C}$, degrees Celsius; $\mu \mathrm{S} / \mathrm{cm}$, microsiemens per centimeter at $25^{\circ} \mathrm{C} ; 1,000$ $\mathrm{col} / 100 \mathrm{ml}$, thousand colonies per 100 milliliters; --, no data collected; <, less than; all water-quality characteristics except temperature, $\mathrm{pH}$, specific conductance, and denitrifying bacteria are for dissolved (filtered) samples]

\begin{tabular}{|c|c|c|c|c|c|}
\hline \multirow{2}{*}{$\begin{array}{l}\text { Water-quality } \\
\text { characteristic }\end{array}$} & \multicolumn{5}{|c|}{$\begin{array}{l}\text { Median value for water samples from } \\
\text { indicated well }\end{array}$} \\
\hline & $2-5 B$ & $2-6 B$ & 2-7B & $2-8 B$ & $2-9$ \\
\hline Temperature $\left({ }^{\circ} \mathrm{C}\right)$ & 22.5 & 23.0 & 22.5 & 22.5 & 23.0 \\
\hline $\mathrm{pH}$ (pH units) & 7.4 & 7.6 & 7.7 & 7.6 & 7.5 \\
\hline $\begin{array}{l}\text { Specific conductance } \\
(\mu \mathrm{S} / \mathrm{cm})\end{array}$ & 550 & 400 & 360 & 330 & 410 \\
\hline Nitrate $^{1}$ & .06 & 2.4 & 3.3 & .03 & .59 \\
\hline Nitrite nitrogen ${ }^{1,2}$ & $<.01$ & $<.01$ & $<.01$ & $<.01$ & .01 \\
\hline Kjeldahl nitrogen ${ }^{2}$ & .28 & $<.20$ & $<.20$ & $<.20$ & $<.20$ \\
\hline Ammonia nitrogen ${ }^{2}$ & .16 & .01 & .01 & .01 & .02 \\
\hline Phosphorus ${ }^{2}$ & .03 & .03 & .06 & $<.02$ & $<.02$ \\
\hline Chloride & 6.2 & 5.4 & 5.4 & 3.4 & 5.6 \\
\hline Oxygen & .3 & .6 & 5.6 & .4 & .5 \\
\hline Inorganic carbon & 50 & 45 & 38 & 32 & 38 \\
\hline $\begin{array}{l}\text { Denitrifying bacter } \\
(1,000 \mathrm{col} / 100 \mathrm{ml})^{3}\end{array}$ & 2.8 & 35 & -- & -- & 110 \\
\hline
\end{tabular}

${ }^{1}$ Nitrite plus nitrate nitrogen.

${ }^{2}$ Values below detection limits are calculated as $1 / 2$ of the detection limit, unless otherwise noted. limits.

${ }^{3}$ Values above dilution detection limits are calculated using those

\section{Dairy Farm 3}

Fluctuations of nitrate concentrations in water samples from the nine shallow wells and from the five deep wells (figs. 12,13), all of which are completed in the Upper Floridan aquifer at dairy farm 3 are described in the following two sections. Because synthetic fertilizers are not applied to this farm or to the upgradient property, elevated concentrations of nitrate in ground water beneath this farm were probably due to leachate from livestock wastes or soils.

\section{Water from Shallow Wells}

Median nitrate concentrations in water from all of the shallow monitoring wells at dairy farm 3 were greater than the median concentration in water from background wells completed in the Upper Floridan aquifer in this county (table 6). Water from shallow monitoring wells near the wastewater lagoon (wells 3-1, 3-3, and 3-9) and the intensive-use area (well 36 ) at this farm generally had the highest nitrate concentrations. Water from wells 3-1, and 3-3, which are next to the former site of an unlined wastewater lagoon (fig. 5), had the highest median concentrations of nitrate $(28 \mathrm{mg} / \mathrm{L}$ and $72 \mathrm{mg} / \mathrm{L}$, respectively) of the monitoring wells at this farm. Nitrate concentrations in water from both of these wells decreased substantially in 1991 (fig. 12), after a new wastewater lagoon was installed approximately $150 \mathrm{ft}$ further east of these wells. Water from well 3-9, which is in the southern pasture further away from the previous site of a wastewater lagoon (fig. 4), had an elevated median concentration of nitrate $(13 \mathrm{mg} / \mathrm{L})$, with a maximum nitrate concentration of $49 \mathrm{mg} / \mathrm{L}$ (fig. 13), indicating that shallow ground water near this well was affected by leachate from the wastewater lagoon or from livestock wastes deposited on the surrounding pasture. The median nitrate concentration in water from well 3-6 (27 $\mathrm{mg} / \mathrm{L})$, which is immediately downgradient from the intensive-use area at this farm, indicated that the quality of shallow ground water near this well was affected by leachate from livestock wastes. Nitrate concentrations in water from well 3-6 were generally close to the median value, with a maximum concentration of $38 \mathrm{mg} / \mathrm{L}$ occurring in a water sample collected from this well in September, 1992 (fig. 12). 

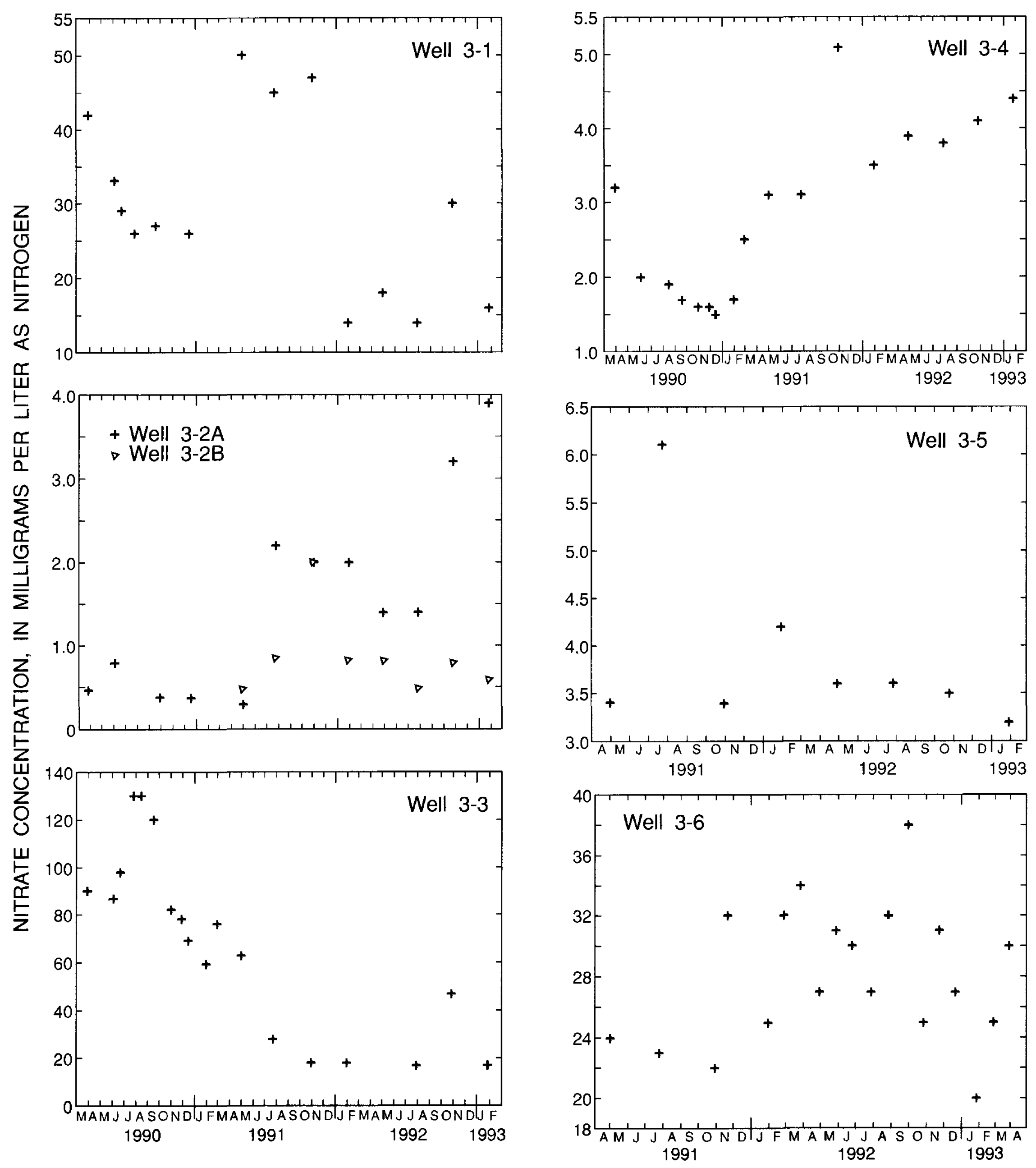

Figure 12. Nitrate concentrations in water from wells at dairy farm 3 in Lafayette County, 1990-93. 

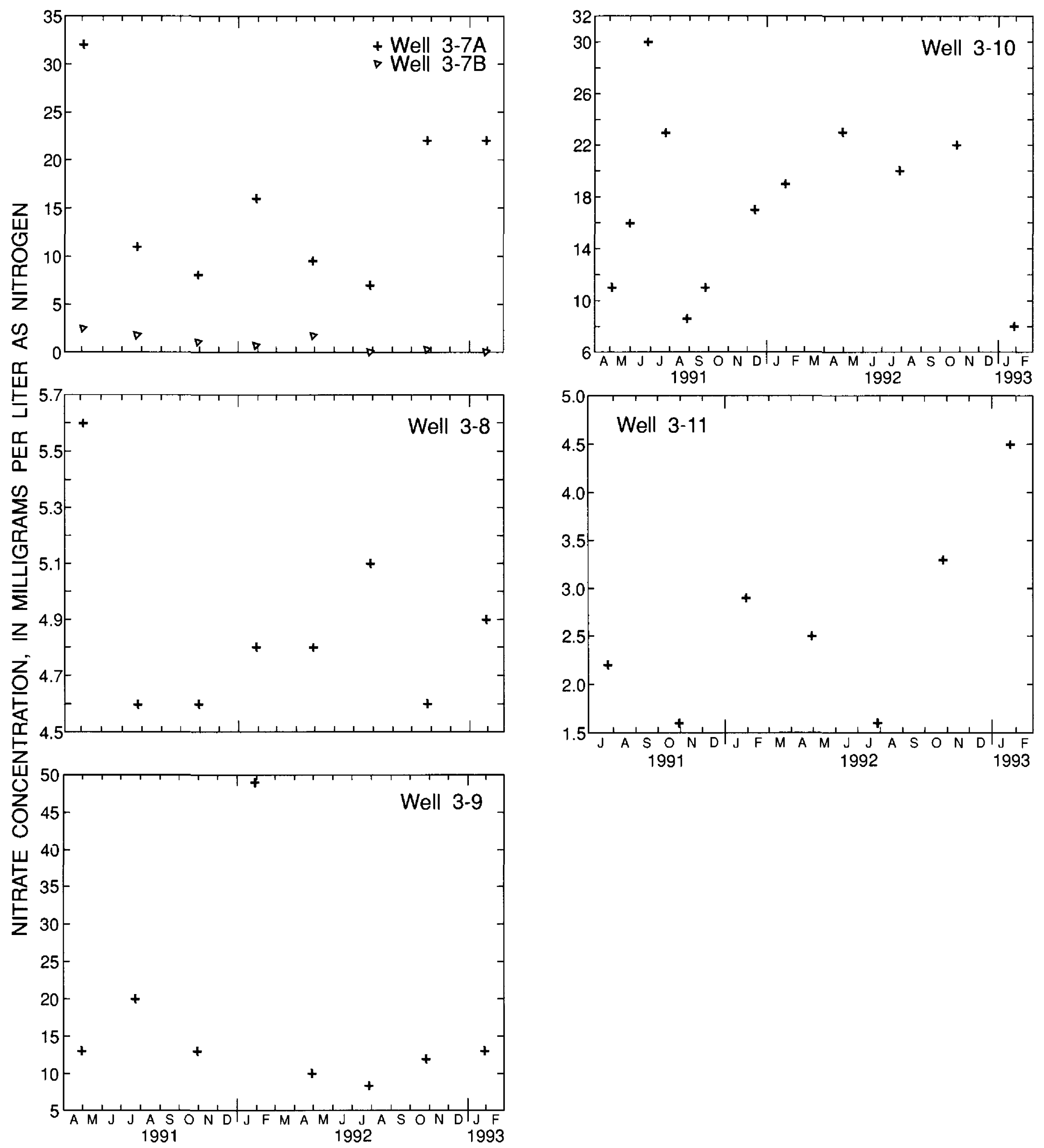

Figure 13. Nitrate concentrations in water from wells at dairy farm 3 in Lafayette County, 1991-93. 
Table 6. Median values of selected water-quality characteristics in water from shallow monitoring wells at dairy farm 3 , Lafayette County, Florida, 1990-93

[All values in $\mathrm{mg} / \mathrm{L}$ (milligrams per liter) unless stated otherwise; ${ }^{\circ} \mathrm{C}$, degrees Celsius; $\mu \mathrm{S} / \mathrm{cm}$, microsiemens per centimeter at $25^{\circ} \mathrm{C} ; 1,000 \mathrm{col} / 100 \mathrm{ml}$, thousand colonies per 100 milliliters; --, no data collected; <, less than; all water-quality characteristics except temperature, pH, specific conductance, and denitrifying bacteria are dissolved (filtered) samples]

\begin{tabular}{|c|c|c|c|c|c|c|c|c|c|}
\hline \multirow{2}{*}{$\begin{array}{l}\text { Water-quality } \\
\text { characteristic }\end{array}$} & \multicolumn{9}{|c|}{ Median value for water samples from indicated well } \\
\hline & 3-1 & 3-2A & 3-3 & $3-4$ & $3-5$ & 3-6 & 3-7A & $3-8$ & $3-9$ \\
\hline Temperature $\left({ }^{\circ} \mathrm{C}\right)$ & 23.0 & 23.0 & 22.5 & 22.5 & 23.0 & 23.0 & 23.0 & 23.0 & 23.0 \\
\hline $\mathrm{pH}$ (pH units) & 6.7 & 7.7 & 6.6 & 7.4 & 7.6 & 6.9 & 7.5 & 7.8 & 7.2 \\
\hline Specific conductance $(\mu \mathrm{S} / \mathrm{cm})$ & 1,100 & 240 & 1,700 & 340 & 330 & 1,000 & 390 & 290 & 580 \\
\hline Nitrate $^{1,2}$ & 28 & 1.4 & 72 & 3.1 & 3.6 & 27 & 14 & 4.8 & 13 \\
\hline Nitrite nitrogen ${ }^{2}$ & $<.01$ & $<.01$ & $<.01$ & $<.01$ & $<.01$ & $<.01$ & $<.01$ & $<.01$ & $<.01$ \\
\hline Kjeldahl nitrogen ${ }^{2}$ & .37 & .26 & .47 & .27 & $<.20$ & .21 & $<.20$ & $<.20$ & $<.20$ \\
\hline Ammonia nitrogen ${ }^{2}$ & .02 & .01 & .73 & .02 & .01 & .02 & $<.01$ & $<.01$ & $<.01$ \\
\hline Phosphorus $^{2}$ & .09 & .08 & .13 & .06 & .02 & .04 & .04 & .04 & .04 \\
\hline Chloride & 17 & 6.9 & 110 & 5.7 & 6.8 & 37 & 12 & 7.2 & 14 \\
\hline Oxygen & 2.0 & 5.2 & 2.4 & 4.0 & 5.8 & 2.2 & 6.0 & 5.5 & 6.3 \\
\hline Inorganic carbon & 94 & 22 & 76 & 34 & 34 & 78 & 31 & 26 & 47 \\
\hline Denitrifying bacteria $(1,000 \mathrm{col} / 100 \mathrm{ml})^{3}$ & -- & -- & -- & 24 & -- & 22 & -- & 22 & -- \\
\hline
\end{tabular}

Nitrate concentrations were generally lower in water from wells which are upgradient or further than $300 \mathrm{ft}$ from the wastewater lagoon and the intensiveuse area on this farm. Water from wells 3-2A and 3-4, which are in a pasture along the upgradient boundary of this farm (fig. 5), had slightly elevated median nitrate concentrations of $1.4 \mathrm{mg} / \mathrm{L}$ and $3.1 \mathrm{mg} / \mathrm{L}$, respectively. Nitrate concentrations in water from these wells generally increased by a factor of two after April 1991 (fig. 12), perhaps due to leachate from increasing numbers of beef cattle grazing on the upgradient property. Water from well 3-5, which is in a depression northwest of the milking barn, had an elevated median nitrate concentration $(3.6 \mathrm{mg} / \mathrm{L})$ and nitrate concentrations in water from this well ranged from $3.2-6.1 \mathrm{mg} / \mathrm{L}$ (fig. 12), indicating that the quality of shallow ground water in the vicinity of this well was affected by leachate from upgradient sources such as the wastewater lagoon and the intensive-use area at this farm. Water from wells 3-7A and 3-8, which are on the downgradient boundary of the intensive-use pasture (fig. 5), had elevated median nitrate concentrations ( 14 and $4.8 \mathrm{mg} / \mathrm{L}$, respectively). The highest nitrate concentrations in water from these wells (22 and $5.1 \mathrm{mg} / \mathrm{L}$, respectively (fig. 13)) indicate that leachate from livestock wastes deposited on this pasture affected the quality of shallow ground water near these wells.

\section{Water from Deep Wells}

Median nitrate concentrations in water from the four deep monitoring wells at dairy farm 3 (wells 3 2B, 3-7B, 3-10, and 3-11) are greater than the median concentration $(0.23 \mathrm{mg} / \mathrm{L})$ in water samples from background network wells completed in the Upper Floridan aquifer in Lafayette and Suwannee Counties. Water from well 3-10, which is downgradient from the wastewater lagoon and the milking barn (fig. 5), had the highest median nitrate concentration $(18 \mathrm{mg} / \mathrm{L})$ of water from the deeper monitoring wells at this farm (table 7) and nitrate concentrations in water from this well ranged from 8 to $30 \mathrm{mg} / \mathrm{L}$ (fig. 13) indicating that the quality of deeper ground water in the vicinity of this well was affected to a variable extent by livestockwaste leachate. Nitrate concentrations in water from well 3-11, which is downgradient from a pasture (fig. 5), ranged from 1.6 to $4.5 \mathrm{mg} / \mathrm{L}$ (fig. 13), indicating that the quality of deeper ground water near this well was somewhat affected by leachate from livestock wastes or soils. The lowest median concentration of nitrate $(0.80 \mathrm{mg} / \mathrm{L}$, table 7$)$ of water from the deep 
monitoring wells at this farm occurred in water from well 3-2B, which is on the upgradient boundary of this farm. Water from well 3-7B had a slightly higher median nitrate concentration $(0.92 \mathrm{mg} / \mathrm{L})$ than water from well 3-2B. Water from wells 3-2B and 3-7B had lower median concentrations of nitrate than water from the adjacent shallow wells (tables 6,7; figs. 12, 13 ), indicating that the quality of deeper ground water in the vicinity of these wells was less affected by leachate from livestock wastes than that of shallow ground water.

Table 7. Median values of selected water-quality characteristics in water from deep monitoring wells at dairy farm 3, Lafayette County, Florida, 1990-93

[All values in $\mathrm{mg} / \mathrm{L}$ (milligrams per liter) unless stated otherwise; ${ }^{\circ} \mathrm{C}$, degrees Celsius; $\mu \mathrm{S} / \mathrm{cm}$, microsiemens per centimeter at $25^{\circ} \mathrm{C} ; 1,000$ $\mathrm{col} / 100 \mathrm{ml}$, thousand colonies per 100 milliliters; --, no data collected; $<$, less than, all water-quality characteristics except temperature, $\mathrm{pH}$, specific conductance, and denitrifying bacteria are dissolved (filtered) samples]

\begin{tabular}{|c|c|c|c|c|}
\hline \multirow{2}{*}{$\begin{array}{l}\text { Water-quality } \\
\text { characteristic }\end{array}$} & \multicolumn{4}{|c|}{$\begin{array}{l}\text { Median value for water samples from } \\
\text { indicated well }\end{array}$} \\
\hline & $3-2 B$ & 3-7B & $3-10$ & 3-11 \\
\hline Temperature $\left({ }^{\circ} \mathrm{C}\right)$ & 23.0 & 23.0 & 23.0 & 23.0 \\
\hline $\mathrm{pH}$ (pH units) & 7.7 & 7.6 & 7.1 & 7.5 \\
\hline $\begin{array}{l}\text { Specific conductance } \\
(\mu \mathrm{S} / \mathrm{cm})\end{array}$ & 320 & 300 & 740 & 350 \\
\hline Nitrate $^{1,2}$ & .80 & .92 & 18 & 2.4 \\
\hline Nitrite nitrogen ${ }^{2}$ & $<.01$ & $<.01$ & .06 & .01 \\
\hline Kjeldahl nitrogen ${ }^{2}$ & $<.20$ & .20 & 1.6 & $<.20$ \\
\hline Ammonia nitrogen ${ }^{2}$ & $<.01$ & .01 & 1.2 & .01 \\
\hline Phosphorus $^{2}$ & .04 & .04 & .04 & .03 \\
\hline Chloride & 7.6 & 4.6 & 29 & 6.0 \\
\hline Oxygen & 2.0 & .4 & 2.5 & 4.6 \\
\hline Inorganic carbon & 28 & 32 & 54 & 36 \\
\hline $\begin{array}{l}\text { Denitrifying bacteria } \\
(1,000 \mathrm{col} / 100 \mathrm{ml})^{3}\end{array}$ & 2 & - & 1 & $<.1$ \\
\hline
\end{tabular}

\footnotetext{
${ }^{1}$ Nitrate plus nitrite nitrogen.

${ }^{2}$ Values below detection limits are calculated as $1 / 2$ of the detection limit, unless otherwise noted.

${ }^{3}$ Values above dilution detection limits are calculated using those limits.
}

\section{Dairy Farm 4}

Nitrate concentrations in water samples from the nine shallow wells and the four deep wells (figs. 14-16), all of which are completed in the karstic Upper Floridan aquifer, at dairy farm 4 are described in the following two sections. Nitrate in ground water at this farm may be derived from livestock wastes deposited on pastures and applied to spray fields or from synthetic fertilizers applied to spray fields.

\section{Water from Shallow Wells}

Median nitrate concentrations in water from seven of the eight shallow monitoring wells at dairy farm 4 exceeded the median concentration in water from background wells $(0.23 \mathrm{mg} / \mathrm{L})$. Nitrate concentrations were generally highest in water from wells near the intensive-use area, the wastewater lagoon, and the spray fields at this farm. Water from well 4-3, which is next to the intensive-use area (fig. 6), had the highest median nitrate concentration $(62 \mathrm{mg} / \mathrm{L})$ of water from the shallow monitoring wells at this farm (table 8), with nitrate concentrations in water from this well ranging from 37 $67 \mathrm{mg} / \mathrm{L}$ (fig. 14). The lowest nitrate concentrations in water from well 4-3 occurred during wet seasons, when water-table elevations were higher and water-table elevation contours indicated that this well was upgradient, rather than downgradient, from the neighboring intensive-use area (figs. $6,14,15$ ). Water samples from well 4-6, also situated next to the intensiveuse area (fig. 6), had the second-highest median nitrate concentration $(30 \mathrm{mg} / \mathrm{L}$, table 8$)$ of the shallow wells at this farm. Nitrate concentrations in water from this well ranged from $22-43 \mathrm{mg} / \mathrm{L}$ (fig. 16), indicating that shallow ground-water quality near this well was affected by leachate from livestock wastes almost as much as water from well 4-3. Nitrate concentrations in water from wells 4-4A and 4-9, which were in the wastewater spray field at this farm (fig. 6), ranged from $17-31 \mathrm{mg} / \mathrm{L}$ and from $14-20 \mathrm{mg} / \mathrm{L}$, respectively (figs. 14,16 ), probably due to seasonal changes in cropping and fertilization of the spray fields. Water from well 4-7A, which is on the shore of the wastewater lagoon (fig. 6), had relatively low concentrations of nitrate $(0.40-0.81 \mathrm{mg} / \mathrm{L}$, fig. 16) and dissolved oxygen $(<0.1-1.4 \mathrm{mg} / \mathrm{L})$, but had a relatively high median concentration of Kjeldahl nitrogen $(4.2 \mathrm{mg} / \mathrm{L})$ indicating that the quality of shallow ground water in the vicinity of this well was affected by leachate from the neighboring lagoon. But this water may not have contained enough oxygen for nitrification of the leachate to occur. Water from well 4-8A, which is approximately $300 \mathrm{ft}$ southwest of well 4-7A (fig. 5), had much higher concentrations of nitrate $(6.2-10 \mathrm{mg} / \mathrm{L}$, fig. 16) and of dissolved oxygen (1.9-6.9 mg/L) and lower concentrations of Kjeldahl nitrogen (ranging from $<0.20-0.52 \mathrm{mg} / \mathrm{L}$ ) than water from well $4-7 \mathrm{~A}$, indicating that leachate from the wastewater lagoon was nitrified as it flowed toward the south. 

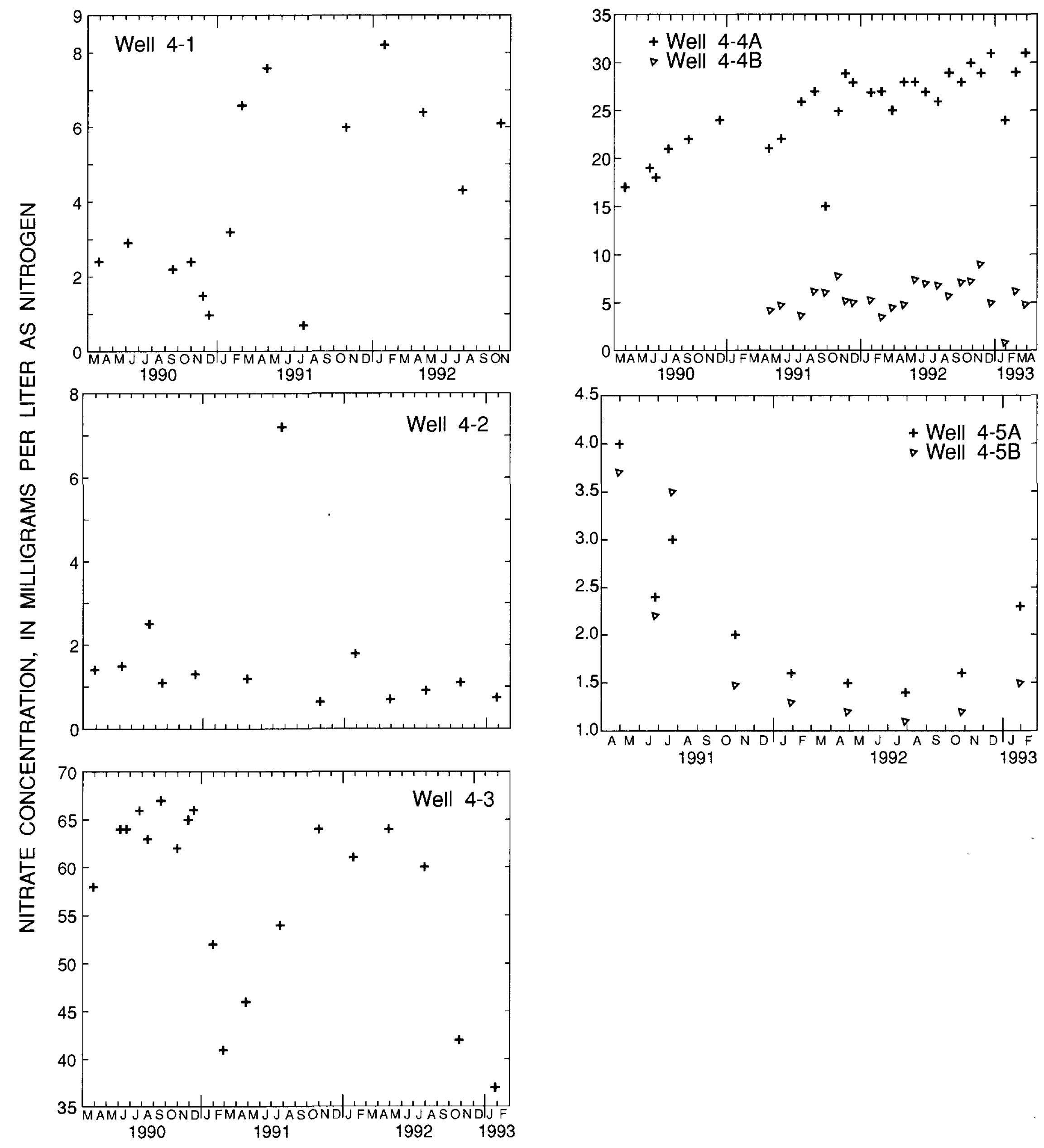

Figure 14. Nitrate concentrations in water from wells at dairy farm 4 in Suwannee County, 1990-93. 


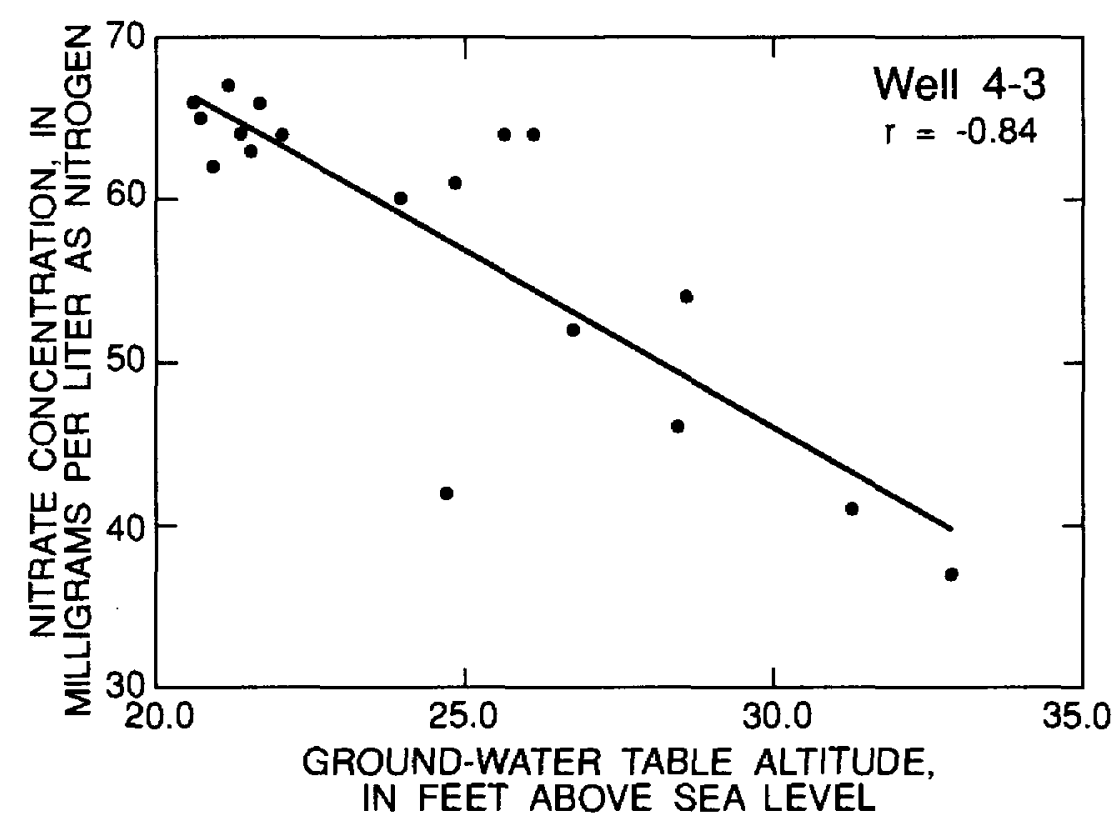

Figure 15. Relation between water-level altitude and nitrate concentration in water from well 4-3 at dairy farm 4 in Suwannee County, 1990-93.
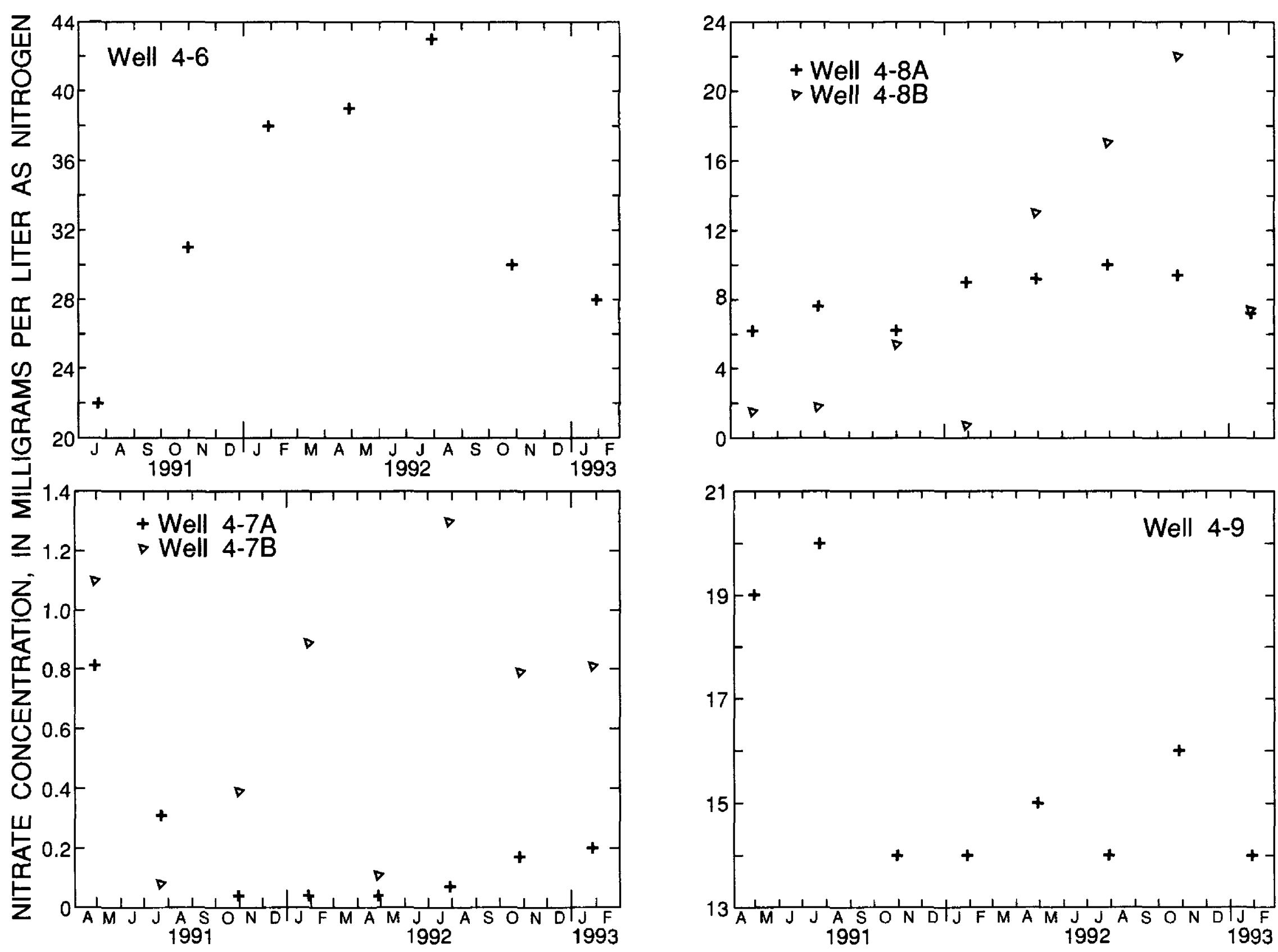

Figure 16. Nitrate concentrations in water from wells at dairy farm 4 in Suwannee County, 1991-93. 
Table 8. Median values of selected water-quality characteristics in water from shallow monitoring wells at dairy farm 4 , Suwannee County, Florida, 1990-93

[All values in $\mathrm{mg} / \mathrm{L}$ (milligrams per liter) unless stated otherwise; ${ }^{\circ} \mathrm{C}$, degrees Celsius; $\mu \mathrm{S} / \mathrm{cm}$, microsiemens per centimeter at $25^{\circ} \mathrm{C} ; 1,000 \mathrm{col} / 100 \mathrm{ml}$, thousand colonies per 100 milliliters; --, no data collected; <, less than; all water-quality characteristics except temperature, $\mathrm{pH}$, specific conductance, and denitrifying bacteria are dissolved (filtered) samples]

\begin{tabular}{|c|c|c|c|c|c|c|c|c|c|}
\hline \multirow{2}{*}{ Water-quality characteristic } & \multicolumn{9}{|c|}{ Median value for water samples from indicated well } \\
\hline & 4-1 & 4-2 & 4-3 & 4-4A & 4-5A & 4-6 & 4-7A & 4-8A & 4-9 \\
\hline Temperature $\left({ }^{\circ} \mathrm{C}\right)$ & 22.5 & 23.0 & 23.0 & 23.0 & 22.5 & 23.0 & 23.0 & 23.0 & 23.0 \\
\hline $\mathrm{pH}$ (pH units) & 6.8 & 6.9 & 6.7 & 7.0 & 7.6 & 7.1 & 6.9 & 7.4 & 7.1 \\
\hline Specific conductance $(\mu \mathrm{S} / \mathrm{cm})$ & 770 & 660 & 1,540 & 820 & 370 & 860 & 980 & 480 & 690 \\
\hline Nitrate ${ }^{1,2}$ & 3.2 & 1.2 & 62. & 27. & 2.0 & 30. & .12 & 8.3 & 14. \\
\hline Nitrite nitrogen ${ }^{2}$ & $<.01$ & $<.01$ & .01 & $<.01$ & $<.01$ & $<.01$ & $<.01$ & $<.01$ & $<.01$ \\
\hline Kjeldahl nitrogen ${ }^{2}$ & .35 & .38 & $<.20$ & .23 & $<.20$ & .25 & 4.2 & $<.20$ & .24 \\
\hline Ammonia nitrogen ${ }^{2}$ & .03 & .01 & .01 & .01 & $<.01$ & .02 & 3.0 & .02 & .01 \\
\hline Phosphorus $^{2}$ & .09 & .06 & .08 & .07 & .04 & .07 & .04 & .03 & .12 \\
\hline Chloride & 19. & 11. & 160. & 24. & 5.1 & 34. & 51. & 12. & 26. \\
\hline Oxygen & 3.8 & 3.2 & 1.9 & 5.8 & 2.6 & 2.8 & .2 & 6.0 & 3.8 \\
\hline Inorganic carbon & 84. & 78 . & 80. & 63. & 36. & 58. & 100. & 43. & 54. \\
\hline $\begin{array}{l}\text { Denitrifying bacteria } \\
(1,000 \mathrm{col} / 100 \mathrm{ml})^{3}\end{array}$ & 120 & 24 & 9 & 240 & 24 & -- & -- & .7 & -- \\
\hline
\end{tabular}

${ }^{1}$ Nitrite plus nitrate nitrogen.

${ }^{2}$ Values below detection limits are calculated as $1 / 2$ of the detection limit, unless otherwise noted.

${ }^{3}$ Values above dilution limits are calculated using those limits.

Water from the other shallow monitoring wells near the wastewater lagoon (wells 4-1, 4-2) and from a shallow well in a pasture (4-5A) had lower nitrate concentrations than the other shallow monitoring wells at dairy farm 4 , but the medians and ranges of nitrate concentrations in water from these wells indicate that the quality of shallow ground water in the vicinity of these wells was affected by leachate from livestock wastes. Water from well 4-1, which lies east of the wastewater lagoon (fig. 6), had an elevated median concentration of nitrate $(3.2 \mathrm{mg} / \mathrm{L})$, and nitrate concentrations ranging up to $8.2 \mathrm{mg} / \mathrm{L}$ (fig. 14). The highest nitrate concentration in water samples from well 4-2, which lies west of the wastewater lagoon (fig. 6), was $7.2 \mathrm{mg} / \mathrm{L}$ in a sample collected in July 1991 (fig. 14). Nitrate concentrations in the other water samples from this well were less than $3.0 \mathrm{mg} / \mathrm{L}$ and the median nitrate concentration was $1.2 \mathrm{mg} / \mathrm{L}$ in water from that well. The range of nitrate concentrations (1.5-3.0 mg/L, fig. 14) in water from well 4-5A, which is in the northwestern pasture (fig. 6), and the median nitrate concentration of 2.0 $\mathrm{mg} / \mathrm{L}$, in water from this well indicate that the quality of shallow ground water in the vicinity of this well was affected by leachate from livestock waste.

\section{Water from Deep Wells}

The median nitrate concentrations in water from the four deep monitoring wells at dairy farm 4 (wells 4$4 \mathrm{~B}, 4-5 \mathrm{~B}, 4-7 \mathrm{~B}$, and 4-8B) were all higher than the median concentration $(0.23 \mathrm{mg} / \mathrm{L})$ in water from background wells completed in the Upper Floridan aquifer in Lafayette and Suwannee Counties. Nitrate concentrations in water from well 4-4B ranged from $0.81-9.0 \mathrm{mg} / \mathrm{L}$ (fig. 14), probably due to seasonal changes in fertilization or cropping of the surrounding spray fields. Although nitrate concentrations in water from this well were approximately one-fourth of those in the neighboring shallow well (well 4-4A), nitrate concentrations in water from well 4-4B closely followed the trend of nitrate concentrations in water from the adjacent shallow well. The similar pattern of nitrate concentrations in water from these wells indicates that water sampled from these wells probably was recharged from the same land-use area. Water from well 4-5B had nitrate concentrations which were similar to, but only slightly lower than those in the adjacent shallow well, 4-5A (fig. 14), suggesting that water sampled from these wells was probably recharged from the same land-use area or that these wells were completed in the same conduit system in the karstic Upper Floridan aquifer. The lowest median 
concentrations of nitrate $(0.80 \mathrm{mg} / \mathrm{L})$, and of dissolved oxygen $(0.4 \mathrm{mg} / \mathrm{L})$ and the highest median

concentrations of Kjeldahl nitrogen $(9.9 \mathrm{mg} / \mathrm{L})$ of water from the deeper monitoring wells at this farm occurred in water from well 4-7B (table 9), indicating that the quality of deeper ground water near this well was affected by unnitrified wastewater leaching from the adjacent lagoon, as was the case with the neighboring shallow well, 4-7A. Water from well 4-8B had the highest median nitrate concentration $(6.4 \mathrm{mg} / \mathrm{L})$ of the deeper monitoring wells at this farm (table 9), indicating that the quality of deeper ground water near this well was affected by leachate from the adjacent wastewater lagoon, but to a lesser extent than shallow ground water in the vicinity of this well (fig. 16). Nitrate concentrations in water from wells $4-7 \mathrm{~B}$ and $4-8 \mathrm{~B}$ did not parallel those in water from their neighboring shallow wells, indicating that deeper ground water near these wells was recharged from different land-use areas or that these wells were completed in different conduit systems in the karstic Upper Floridan aquifer than the neighboring shallow wells.

Table 9. Median values of selected water-quality characteristics in water from deep monitoring wells at dairy farm 4, Suwannee County, Florida, 1990-93

[All values in $\mathrm{mg} / \mathrm{L}$ (milligrams per liter) unless stated otherwise; ${ }^{\circ} \mathrm{C}$, degrees Celsius; $\mu \mathrm{S} / \mathrm{cm}$, microsiemens per centimeter at $25^{\circ} \mathrm{C} ; 1,000$ $\mathrm{col} / 100 \mathrm{ml}$, thousand colonies per 100 milliliters; --, no data collected; <, less than; all water-quality characteristics except temperature, $\mathrm{pH}$, specific conductance, and denitrifying bacteria are dissolved (filtered) samples]

\begin{tabular}{|c|c|c|c|c|}
\hline \multirow{2}{*}{$\begin{array}{l}\text { Water-quality } \\
\text { characteristic }\end{array}$} & \multicolumn{4}{|c|}{$\begin{array}{l}\text { Median value for water samples from } \\
\text { indicated well }\end{array}$} \\
\hline & $4-4 B$ & 4-5B & $4-7 B$ & $4-8 B$ \\
\hline Temperature $\left({ }^{\circ} \mathrm{C}\right)$ & 23.0 & 23.0 & 23.0 & 23.0 \\
\hline $\mathrm{pH}$ (pH units) & 7.5 & 7.7 & 7.0 & 7.3 \\
\hline $\begin{array}{l}\text { Specific conductance } \\
(\mu \mathrm{S} / \mathrm{cm})\end{array}$ & 390 & 380 & 870 & 460 \\
\hline Nitrate $^{1,2}$ & 5.3 & 1.5 & .80 & 6.4 \\
\hline Nitrite nitrogen ${ }^{2}$ & $<.01$ & $<.01$ & $<.01$ & .01 \\
\hline Kjeldahl nitrogen ${ }^{2}$ & .20 & $<.20$ & 9.9 & .21 \\
\hline Ammonia nitrogen ${ }^{2}$ & .01 & .01 & 8.5 & .02 \\
\hline Phosphorus $^{2}$ & .04 & .03 & .04 & .26 \\
\hline Chloride & 6.5 & 5.0 & 34. & 7.9 \\
\hline Oxygen & 3.9 & 2.4 & .4 & 2.1 \\
\hline Inorganic carbon & 37 & 37 & 94 & 48 \\
\hline $\begin{array}{l}\text { Denitrifying bacteria } \\
\qquad(1,000 \mathrm{col} / 100 \mathrm{ml})^{3}\end{array}$ & .70 & 21 & - & - \\
\hline
\end{tabular}

${ }^{1}$ Nitrite plus nitrate nitrogen

${ }^{2}$ Values below detection limits are calculated as $1 / 2$ of the detection limit unless otherwise noted.

${ }^{3}$ Values above dilution detection limits are calculated using those limits.

\section{Nitrate Concentrations in Spring Water}

To evaluate the quality of ground water discharging to the Suwannee River in the study area, three springs--Blue, Telford, and Convict (fig. 1), were sampled periodically during 1991-93. During approximately six months of each year, the Suwannee River rises above the potentiometric elevations of the Upper Floridan aquifer at these springs, and river water flows through the spring vents into the aquifer. These springs were sampled only when ground water was discharging from the spring vents.

Nitrate concentrations were relatively constant in ground water discharged to the Suwannee River at these three springs. The relatively high concentrations of nitrate in water from these springs, compared to concentrations in water from background wells in these counties, indicate that the quality of ground water discharged to the Suwannee River at these springs was affected by anthropogenic sources such as fertilizers, septic tanks, and livestock operations such as dairy farms or poultry houses located in the contributing areas of these springs.Nitrate concentrations in water from Blue Spring and Telford Spring decreased slightly from 1991-93 (fig. 17). The median concentration of nitrate was approximately three times higher in water from Convict Spring $(6.6 \mathrm{mg} / \mathrm{L})$ than in water from Blue Spring $(2.0 \mathrm{mg} / \mathrm{L})$ and Telford Spring $(2.2 \mathrm{mg} / \mathrm{L})$ (table 10). The elevated nitrate concentrations in water from Convict Spring (5.4-7.2 mg/L, fig. 17) may be derived from leachate from septic tanks at a development surrounding the spring or from fertilized cropland several hundred feet south of the spring. One water sample from Convict Spring was analyzed for methylene blue active substances (MBAS), a component of detergent, to determine if leachate from septic tank drainfields was the principal source of the elevated nitrate concentrations in water discharging from this spring. The concentration of MBAS in that water sample was below the detection limit of $0.1 \mathrm{mg} / \mathrm{L}$, but some studies (Alhajjar and others, 1987) have suggested that detergent constituents such as MBAS can be degraded in septic tanks, so the lack of detectable MBAS in water discharged at this spring does not definitively rule out septic-tank leachate as a source of the relatively high concentrations of nitrate in this water. 


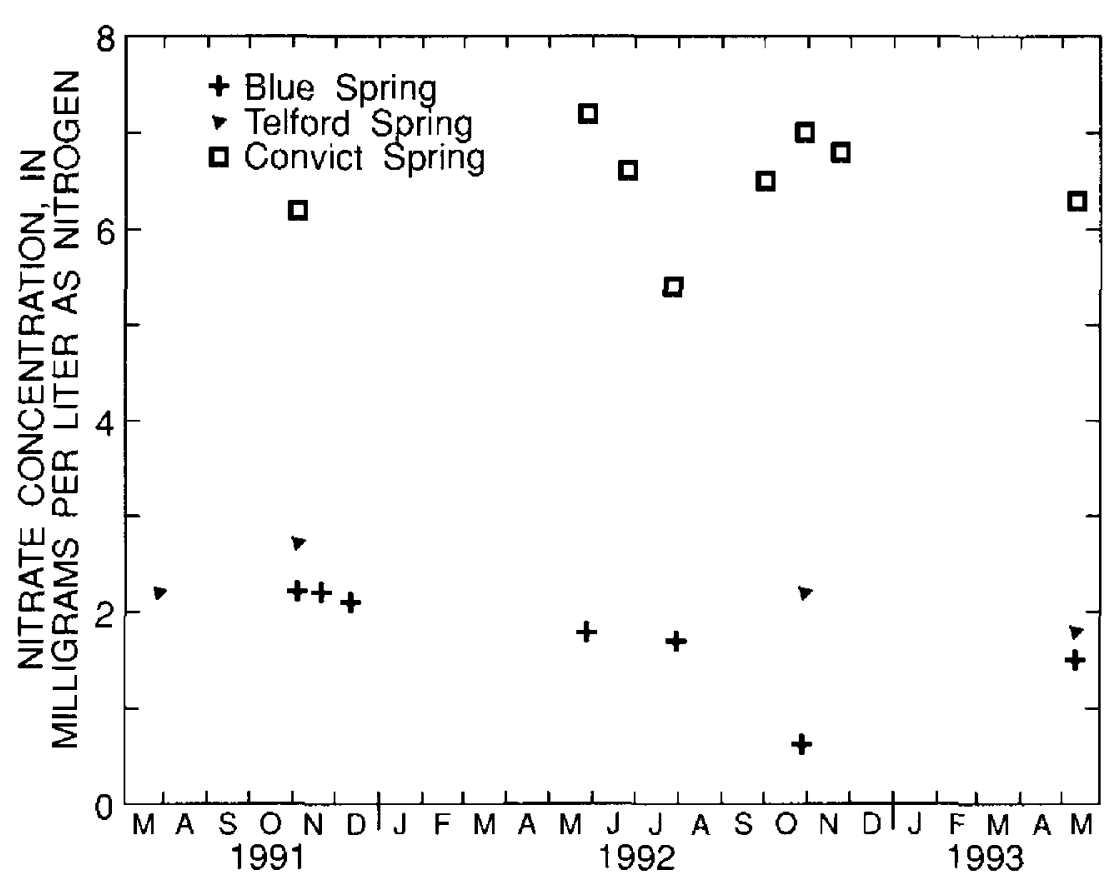

Figure 17. Nitrate concentrations in water from Blue, Telford, and Convict Springs, Lafayette and Suwannee Counties, Florida, 1991-93.

Table 10. Median values of selected water-quality characteristics from Blue, Telford, and Convict springs ${ }^{1}$ Lafayette and Suwannee Counties, Florida, 1991-93

[All values in $\mathrm{mg} / \mathrm{L}$ (milligrams per liter) unless stated otherwise; ${ }^{\circ} \mathrm{C}$, degrees Celsius; $\mu \mathrm{S} / \mathrm{cm}=$ microsiemens per centimeter at $25^{\circ} \mathrm{C} ; 1,000$ $\mathrm{col} / 100 \mathrm{ml}$, thousand colonies per 100 milliliters; --, no data collected; <, less than; all water-quality characteristics except temperature, $\mathrm{pH}$, specific conductance, and denitrifying bacteria are dissolved (filtered) samples]

\begin{tabular}{lccc}
\hline & \multicolumn{3}{c}{ Median value for water sam- } \\
ples from indicated spring
\end{tabular}

${ }^{1}$ Nitrite plus nitrate nitrogen.

${ }^{2}$ Values below detection limits are calculated as $1 / 2$ of the detection limit unless otherwise noted.

${ }^{3}$ Values based on 1 sample.
Although phosphorus is also a prominent constituent in livestock wastes, having a median concentration of $25 \mathrm{mg} / \mathrm{L}$ in samples collected from wastewater lagoons for Andrews (1992), phosphorus concentrations in water from most of the 51 monitoring wells at the 4 dairy farms were generally low--near the detection limit of $0.02 \mathrm{mg} / \mathrm{L}$ (tables 210). The relatively low concentrations of phosphorus in ground water from the monitoring wells at the four dairy farms and in water discharged at these springs (table 12) indicate that phosphorus in leachate from animal wastes and from other sources was sorbed to soils and to sands and clays in the unsaturated zone or to aquifer materials, and that nitrate was the principal nutrient discharged in ground water to the Suwannee River in Lafayette and Suwannee Counties in North Florida.

\section{SOURCES OF NITRATE IN GROUND WATER INDICATED BY NITROGEN ISOTOPE RATIOS}

Sources of nitrate in water can be qualitatively determined by analysis of nitrogen isotope ratios analysis, in which the ratio of the two stable isotopes of nitrogen, ${ }^{14} \mathrm{~N}$ and ${ }^{15} \mathrm{~N}$, in dissolved nitrate are compared to the ratio of these isotopes in a standard of atmospheric nitrogen gas (Delwiche and Steyn, 1970; Bottcher and others, 1990). Atmospheric nitrogen gas consists principally of ${ }^{14} \mathrm{~N}(99.632 \pm 0.0002$ percent $)$ (Nier, 1955). The ratio of nitrogen isotopes $\delta^{15} \mathrm{~N}$ in dissolved nitrate is expressed in parts per thousand (ppt) as, and is calculated using the following equation:

$$
\delta{ }^{15} \mathrm{~N}=\frac{\left({ }^{15} \mathrm{~N} /{ }^{14} \mathrm{~N}\right) \text { sample-( }\left({ }^{15} \mathrm{~N} /{ }^{14} \mathrm{~N}\right) \text { standard }}{\left({ }^{15} \mathrm{~N} /{ }^{14} \mathrm{~N}\right) \text { standard }} \times 1,000
$$

Samples depleted in ${ }^{15} \mathrm{~N}$ relative to the atmosphere have negative $\delta^{15} \mathrm{~N}$ values, whereas samples enriched in ${ }^{15} \mathrm{~N}$ relative to atmospheric nitrogen have positive $\delta^{15} \mathrm{~N}$ values.

Nitrate leached from synthetic fertilizers, the principal type of nitrogen fertilizers applied in the U.S., has $\delta^{15} \mathrm{~N}$ values ranging from -3 to $+2 \mathrm{ppt}$ (Krietler, 1975). Synthetic fertilizers have nitrogen isotope ratios similar to atmospheric nitrogen because they are derived from atmospheric nitrogen through the Haber-Bosch process, which combines nitrogen 
and hydrogen gases under high pressures and temperatures, in the presence of a platinum catalyst, to create anhydrous ammonia. Anhydrous ammonia created by this process can be further processed to make ammonium nitrate and urea, the most common synthetic nitrogen fertilizers applied in North Florida. Nitrate leached from soils typically has $\delta^{15} \mathrm{~N}$ values ranging from +2 to $+8 \mathrm{ppt}$ (Kreitler, 1975).

Enrichment of ${ }^{15} \mathrm{~N}$ in nitrate leached from soils may be caused by the more thermodynamically efficient preferential uptake of lighter nitrate molecules by plant roots and soil bacteria (Delwiche and Steyn, 1970). In a humid, thermic environment, such as that in North Florida, only a minimal amount of nitrate should leach from undisturbed soils. Nitrogen isotope ratios in nitrate leached from animal wastes are relatively enriched in ${ }^{15} \mathrm{~N}$, with $\delta^{15} \mathrm{~N}$ values ranging from +10 to $+20 \mathrm{ppt}$, because lighter ammonia molecules (containing the ${ }^{14} \mathrm{~N}$ atom) preferentially evaporate from wastes after deposition on the land surface (Kreitler, 1975; Watkins and others, 1972). Denitrification increases the $\delta^{15} \mathrm{~N}$ values of nitrate because uptake and reduction of lighter nitrate molecules is more thermodynamically efficient for denitrifying bacteria (Wellman and others, 1968).

Nitrogen isotope ratio analyses were performed on water samples collected from wells 1-1, 1-4A, 14B, 2-4, 2-6A, 2-6B, 3-3, 4-4A, and 4-4B in July 1991 to determine the sources of nitrate in shallow and deeper ground water adjacent to common land uses on dairy farms. These wells were selected for nitrogenisotope-ratio analysis because of the diversity of land uses adjacent to these wells. The nitrogen isotope ratio $(35.0 \mathrm{ppt})$ of nitrate in water from well $1-1$ exceeded the range of $10-20 \mathrm{ppt}$ normally attributed to animal wastes, indicating that processes such as ammonia volatilization from the nearby wastewater lagoon or denitrification in ground water could have fractionated the nitrate leached to shallow ground water in the vicinity of this well. The nitrogen isotope ratio (8.2 ppt) for nitrate in water from well 1-4A was slightly below the range for nitrate leached from animal wastes, indicating that leachate from defoliated soils in the adjacent intensive-use area as well as livestock wastes deposited on that area, may have been the sources of nitrate in this water. The nitrogen isotope ratio in a water sample from well $1-4 \mathrm{~B}(32.9 \mathrm{ppt})$, was above the range attributed to animal waste leachate, indicating that denitrification may have occurred in deeper ground water in the vicinity of this well or that water sampled from this well was recharged from a different land-use area than shallow ground water from the adjacent well. The relatively light nitrogen isotope ratio $(0.89 \mathrm{ppt})$ of nitrate in a water sample from well 2-4 indicated that the source of nitrate in that water sample was synthetic fertilizers, indicating that leachate from the upgradient spray fields, to which synthetic fertilizers were applied, may have been affecting the quality of shallow ground water in the vicinity of this well. The nitrogen-isotope ratio of nitrate $(31.6 \mathrm{ppt})$ in a water sample collected from well $2-6 \mathrm{~A}$ indicated that leachate from livestock wastes was the principal source of nitrate in that water sample and that ammonia volatilization may have isotopically fractionated nitrogen in wastewater as it was applied to the upgradient spray field. The nitrogen-isotope ratio in nitrate in a water sample from the adjacent deeper well $2-6 \mathrm{~B}(-3.00 \mathrm{ppt})$ indicated that synthetic fertilizers were the principal source of nitrate in that sample. The dramatically different nitrogen-isotope ratios in nitrate in water from the shallow well 2-6A and the deep well 2-6B, indicates that these wells were completed in different conduit systems with different areas of contribution. The nitrogen-isotope ratio in nitrate in a water sample from well 3-3 (5.19 ppt) indicated that nitrate in water from this well may have been derived from leachate from soils or a mixture of leachate from livestock wastes and synthetic fertilizers. The water sample from well 3-3 was collected after the wastewater lagoon had been moved $150 \mathrm{ft}$ downgradient from this well and nitrate concentrations had declined from more than $50 \mathrm{mg} / \mathrm{L}$ to less than $20 \mathrm{mg} / \mathrm{L}$ in water from this well (fig. 12). The nitrogen isotope ratios in water from wells $4-4 \mathrm{~A}$ and 4-4B (25.6 and $1.22 \mathrm{ppt}$, respectively) indicate that the quality of shallow ground water in the vicinity of these wells was affected by animal-waste leachate, but that the quality of deeper ground water was affected by leachate from synthetic fertilizers, indicating that the water sampled from these wells was recharged at different land-use areas.

The nitrogen-isotope ratios of nitrate in water samples collected from Blue (9.65 ppt), Telford (7.7 ppt) and Convict (8.9 ppt) Springs in May 1993 indicated that the source of nitrate in water discharged by these springs to the Suwannee River at that time was probably a combination of leachate from livestock wastes, septic tanks, soil nitrogen, and synthetic fertilizers. Because these ratios were just slightly below the range of $10-20 \mathrm{ppt}$ commonly assigned to 
animal-waste sources of nitrate, these ratios indicate that leachate from livestock wastes and septic tanks was probably the principal source of nitrate in these water samples.

\section{TRANSFORMATION OF NITRATE IN GROUND WATER}

Denitrification and dilution are the two principal processes that can reduce nitrate concentrations in ground water. Denitrification, which reduces nitrate to nitrite and nitrous oxide and nitrogen gases, can occur in anaerobic or nearly-anaerobic ground water through two bacterially-mediated processes: the heterotrophic process, which requires a carbon substrate and facultative heterotrophic bacteria; or the autotrophic process, which requires autotrophic bacteria and reduced manganese, iron, or sulfide compounds (Korom, 1992; Lind, 1985). Because reduced metal compounds such as pyrite were not detected in cuttings from the wells drilled for this investigation, heterotrophic denitrification is presumed to be the primary mechanism for denitrification in ground water in the uppermost aquifers in north Florida. In anaerobic water, heterotrophic denitrifying bacteria respire by removing oxygen atoms from nitrate molecules, as expressed by the following reaction equation for a carbonate aquifer:

$$
\begin{gathered}
4 \mathrm{NO}_{3}{ }^{-}+5 / 6 \mathrm{C}_{6} \mathrm{H}_{12} \mathrm{O}_{6}(\text { glucose })+5 \mathrm{CaCO}_{3}+4 \\
\mathrm{H}^{+}-->2 \mathrm{~N}_{2}+10 \mathrm{HCO}_{3}^{-}+5 \mathrm{Ca}^{+2}+2 \mathrm{H}_{2} \mathrm{O} .
\end{gathered}
$$

Denitrification requires nitrate and an organic substrate (glucose is shown as an example) and produces the intermediate products nitrite and nitrous oxide gas (not shown in the reaction equation). Denitrification also increases the $\mathrm{pH}$ of water, and produces dinitrogen gas $\left(\mathrm{N}_{2}\right)$, bicarbonate (the principal form of dissolved inorganic carbon), and water. Elevated concentrations of dissolved inorganic carbon can be an indicator of denitrification, however, in carbonate aquifers such as the Upper Floridan aquifer, acids produced by nitrification of leachate from livestock wastes may dissolve carbonate minerals, meaning that elevated concentrations of dissolved inorganic carbon in this aquifer might be related to nitrification rather than to denitrification.

Denitrifying bacteria commonly occurred in counts exceeding 100,000 colonies per $100 \mathrm{~mL}$ sample, but because these bacteria are viable in aerobic and anaerobic conditions, the presence of these bacteria do not necessarily indicate the occurrence of denitrification. Bacterial denitrification in nitrate-rich ground water is inhibited by three primary factors: the presence of dissolved oxygen, lack of a carbon substrate, and pH levels less than 5.0 (Bradley and others, 1992). Although denitrification can occur only in anoxic water, dissolved oxygen concentrations less than $1.0 \mathrm{mg} / \mathrm{L}$ were considered to indicate near-anoxic conditions for this report. Periodic measurements of dissolved oxygen concentrations below $1.0 \mathrm{mg} / \mathrm{L}$ indicated that denitrification could occur at least periodically in shallow ground water in the vicinity of wells $1-2,1-3,1-5 \mathrm{~A}$, and 1-6 and in deeper ground water in the vicinity of wells $1-4 \mathrm{~B}$ and $1-5 \mathrm{~B}$ at dairy farm 1. Dissolved oxygen concentrations were periodically less than $1.0 \mathrm{mg} / \mathrm{L}$ in water from wells $2-2$, $2-5 \mathrm{~A}, 2-5 \mathrm{~B}, 2-8 \mathrm{~A}, 2-8 \mathrm{~B}$, and $2-9$, indicating that denitrification could occur occasionally in ground water in the vicinity of these three wells at dairy farm 2 . Well 3-7B was the only well at dairy farm 3 from which water samples had dissolved oxygen concentrations that were usually less than $1.0 \mathrm{mg} / \mathrm{L}$, indicating that denitrification may occur in deeper ground water in the vicinity of that well. Dissolved oxygen concentrations were periodically less than $1.0 \mathrm{mg} / \mathrm{L}$ in water from wells 4-4B, 4-7A, and 4-7B at dairy farm 4, indicating that denitrification could occur occasionally in ground water in the vicinity of these wells. The relatively high median concentrations of dissolved oxygen in water from Blue, Telford, and Convict Springs (ranging from 1.9- $4.0 \mathrm{mg} / \mathrm{L}$ ) indicated that denitrification was unlikely to occur in this water prior to discharging to the Suwannee River.

To evaluate factors limiting denitrification in ground water at dairy farms in North Florida, nitrate and nitrite concentrations in three sealed ground-water samples from two dairy-farm monitoring wells (two from well 2-6A completed in the Upper Floridan aquifer, and one from well 1-4A, completed in the surficial aquifer), were analyzed periodically for up to two weeks after collection (table 11). Nitrate and nitrite concentrations in water collected from well 2-6A on January 27, 1992 did not change significantly for several days after sample collection, indicating that denitrification was not occurring (table 11).

Denitrification may have been inhibited by the presence of oxygen (oxygen-limited) or by the lack of organic substrates (carbon-limited) in this water. To test whether denitrification was carbon-limited, $5 \mathrm{~mL}$ of saturated glucose solution was added to the water sample collected from well 2-6A on April 27, 1992. 
Table 11. Time-series water-quality data from sealed denitrification experiments of water from wells 2-6A and $1-4 \mathrm{~A}$ in Lafayette County, Florida

[<, less than; --, no analysis made; $\mathrm{mg} / \mathrm{L}$, milligrams per liter]

\begin{tabular}{|c|c|c|c|c|c|}
\hline $\begin{array}{c}\text { Well } \\
\text { number }\end{array}$ & $\begin{array}{c}\text { Date of } \\
\text { analysis }\end{array}$ & $\begin{array}{c}\text { Nitrate } \\
\text { concen- } \\
\text { tration } \\
(\mathrm{mg} / \mathrm{L})\end{array}$ & $\begin{array}{c}\text { Nitrite } \\
\text { nitrogen } \\
\text { concen- } \\
\text { tration } \\
(\mathrm{mg} / \mathrm{L})\end{array}$ & $\begin{array}{c}\text { Oxygen } \\
\text { concen- } \\
\text { tration } \\
(\mathrm{mg} / \mathrm{L})\end{array}$ & Comments \\
\hline $2-6 \mathrm{~A}$ & $1-27-92$ & 9.4 & -- & -. & \\
\hline $2-6 \mathrm{~A}$ & $1-28-92$ & 9.4 & -- & -- & \\
\hline $2-6 \mathrm{~A}$ & $1-29-92$ & 9.3 & -- & -- & \\
\hline $2-6 \mathrm{~A}$ & $2-01-92$ & 9.3 & - & -- & \\
\hline $2-6 \mathrm{~A}$ & $2-02-92$ & 9.4 & -- & -- & \\
\hline $2-6 \mathrm{~A}$ & $2-03-92$ & 9.3 & -- & -- & \\
\hline $2-6 \mathrm{~A}$ & $2-04-92$ & 9.4 & -- & -- & \\
\hline $2-6 A$ & $2-05-92$ & 9.4 & -- & -- & \\
\hline $2-6 \mathrm{~A}$ & $2-06-92$ & 9.3 & -- & -- & \\
\hline $2-6 \mathrm{~A}$ & $2-07-92$ & 9.3 & -- & -- & \\
\hline $2-6 \mathrm{~A}$ & $2-10-92$ & 9.2 & -- & -- & \\
\hline $2-6 \mathrm{~A}$ & $2-12-92$ & 9.2 & -- & -- & \\
\hline $2-6 \mathrm{~A}$ & $2-14-92$ & 9.2 & -- & -- & \\
\hline $2-6 \mathrm{~A}$ & $4-27-92$ & 4.0 & 0.01 & -- & \\
\hline $2-6 A$ & $4-28-92$ & 3.9 & .01 & -- & \\
\hline $2-6 \mathrm{~A}$ & $4-29-92$ & 3.9 & .01 & -- & \\
\hline $2-6 A$ & $4-30-92$ & 3.9 & .01 & -- & \\
\hline $2-6 \mathrm{~A}$ & $5-01-92$ & 3.9 & .01 & -- & \\
\hline $2-6 \mathrm{~A}$ & 5-04-92 & 3.9 & .01 & -. & \\
\hline $2-6 \mathrm{~A}$ & $5-05-92$ & 3.9 & .01 & -- & \\
\hline $2-6 \mathrm{~A}$ & $5-06-92$ & -- & - & -- & $\begin{array}{l}\text { Glucose } \\
\text { Added }\end{array}$ \\
\hline $2-6 \mathrm{~A}$ & $5-08-92$ & 1.2 & 1.2 & -- & \\
\hline $2-6 A$ & $5-11-92$ & 0.11 & .11 & -- & \\
\hline $2-6 \mathrm{~A}$ & $5-12-92$ & $<.02$ & $<.01$ & -- & \\
\hline $1-4 \mathrm{~A}$ & $7-27-92$ & -- & -- & 4.3 & \\
\hline $1-4 A$ & $7-28-92$ & 23 & $<.01$ & 4.0 & \\
\hline $1-4 \mathrm{~A}$ & $7-29-92$ & 22 & .03 & 1.4 & \\
\hline $1-4 \mathrm{~A}$ & $7-30-92$ & 22 & .39 & 1.4 & \\
\hline $1-4 \mathrm{~A}$ & $7-31-92$ & 22 & .52 & 1.4 & \\
\hline $1-4 \mathrm{~A}$ & $8-03-92$ & 21 & .46 & 1.3 & $\begin{array}{l}\text { Glucose } \\
\text { Added }\end{array}$ \\
\hline $1-4 \mathrm{~A}$ & $8-03-92$ & 22 & .45 & -- & \\
\hline $1-4 \mathrm{~A}$ & $8-04-92$ & 20 & .43 & 1.5 & $\begin{array}{l}\text { Argon } \\
\text { Tank } \\
\text { Changed }\end{array}$ \\
\hline $1-4 \mathrm{~A}$ & $8-04-92$ & 20 & .37 & -- & \\
\hline $1-4 A$ & $8-05-92$ & 20 & .37 & 1.5 & \\
\hline $1-4 \mathrm{~A}$ & $8-05-92$ & 21 & .35 & -- & \\
\hline $1-4 A$ & 8-06-92 & 20 & .39 & 1.9 & \\
\hline $1-4 \mathrm{~A}$ & $8-06-92$ & 20 & .39 & -- & \\
\hline
\end{tabular}

After the glucose solution was added to a water sample from this well, the concentration of nitrate declined from $3.9 \mathrm{mg} / \mathrm{L}$ to less than $1.0 \mathrm{mg} / \mathrm{L}$, and the concentration of nitrite, an intermediate product of denitrification, increased by two orders of magnitude, indicating that denitrification was carbon-limited in this water. Similar results with glucose addition to water were reported by Smith and Duff (1988) and by Obenhuber and Lowrance (1989). The decrease in nitrate concentrations after the addition of glucose to the reaction vessel could also may have been caused by the metabolism of aerobic bacteria depleting the oxygen in the vessel, providing suitable conditions for denitrification. To test whether oxygen was a limiting factor of denitrification in shallow ground water, dissolved oxygen concentrations were also measured in a 5-gallon water sample collected from well 1-4A on July 27,1992 . Addition of glucose did not affect the concentrations of nitrate or oxygen in that water sample, possibly because the low $\mathrm{pH}$ (4.4) of this water inhibited denitrification. Bradley and others (1992) reported that $\mathrm{pH}$ values of 5 or less in water can inhibit denitrification. Because these time-series denitrification experiments were limited in scope, they did not definitively determine whether denitrification in ground water in the region was limited by carbon, oxygen, or $\mathrm{pH}$.

\section{SUMMARY}

Water samples were collected periodically from 51 monitoring wells at 4 typical dairy farms and 3 nearby springs during $1990-93$ in Lafayette and Suwannee Counties in North Florida to assist in the evaluation of the effects of dairy farms on nitrate concentrations in shallow and deeper ground water and in ground water discharged to the Suwannee River. To evaluate nitrate concentrations in shallow ground water, which is most afftected by overlying land uses, 36 of these monitoring wells were completed in the top 10 feet of an unnamed surficial aquifer at one farm, and in the karstic Upper Floridan aquifer at three of the farms. Fifteen of the 51 monitoring wells, referred to as deep wells in this report, were screened $20 \mathrm{ft}$ deeper than shallow wells to evaluate vertical changes of nitrate concentrations in these aquifers. Water from most of these wells and from the three springs had median nitrate concentrations exceeding those in water from wells of the background ground-water quality network sampled 
by the Florida Department of Environmental

Protection $(0.22 \mathrm{mg} / \mathrm{L}$ and $0.23 \mathrm{mg} / \mathrm{L}$ for the surficial and Upper Floridan aquifers, respectively in Lafayette and Suwannee Counties). Near wastewater lagoons and intensive livestock-use areas, where livestock waste-loading rates were highest, nitrate concentrations in shallow ground water commonly exceeded the primary drinking water standard of $10 \mathrm{mg} / \mathrm{L}$ as nitrogen. Nitrate concentrations generally were substantially lower in water from wells in pastures, where livestock-waste loading was much less concentrated. Nitrate concentrations were also generally lower in water from the deep wells, due to either dilution of nitrate with depth, to different land uses in source areas of the water sampled from these wells, or to denitrification in the less oxygenated deeper ground water.

Changes in farm management practices during the course of the investigation induced changes in nitrate concentrations in water from monitoring wells at several of the dairy farms. Since the construction of a new concrete conduit to the wastewater lagoon near well 1-1 at dairy farm 1 , nitrate concentrations in water from that well decreased from $35 \mathrm{mg} / \mathrm{L}$ to about $10 \mathrm{mg} / \mathrm{L}$, indicating that the old conduit might have been leaking wastewater. After the unlined wastewater lagoon at dairy farm 3 was moved $150 \mathrm{ft}$ north from monitoring wells 3-1,3-3, and 3-9, nitrate concentrations in water from these wells decreased substantially. Nitrate concentrations varied seasonally in water from shallow monitoring wells in or downgradient from several of the wastewater spray fields at the four dairy farms, perhaps because of seasonal changes in fertilization and cropping.

Changes in ground-water flow directions between wet and dry periods also caused significant changes in the quality of water from two wells. Water from well 2-1 had nitrate concentrations exceeding $50 \mathrm{mg} / \mathrm{L}$ during dry periods, when this well was downgradient from a wastewater lagoon. During wet periods, when the direction of ground-water flow shifted and this well was no longer downgradient from the wastewater lagoon, nitrate concentrations in water from this well decreased to less than $10 \mathrm{mg} / \mathrm{L}$. Nitrate concentrations also changed, to a lesser extent, in water from well 4-3, which is next to the intensive-use area at dairy farm 4 . During wet periods, when well 43 was not downgradient from the intensive-use area, nitrate concentrations in water from this well were less than $45 \mathrm{mg} / \mathrm{L}$, whereas during drier periods, when this well was downgradient from the intensive-use area, nitrate concentrations in water from this well exceeded $60 \mathrm{mg} / \mathrm{L}$.

To evaluate the concentrations of nitrate and other nutrients in ground water flowing into the spring-fed Suwannee River, three springs--Blue, Telford, and Convict, which are in Lafayette and Suwannee Counties, were periodically sampled from 1991-93. These samples had lower concentrations of nitrate than water from wells near lagoons and intensive-use areas at the monitored dairy farms, but nitrate concentrations in water from these springs exceeded the median concentration in water samples from background wells in these counties. Ground water discharged to the Suwannee River at two of the springs, Blue and Telford, contained approximately $2 \mathrm{mg} / \mathrm{L}$ of nitrate, whereas water discharged at Convict Spring had a median nitrate concentration of $6.6 \mathrm{mg} / \mathrm{L}$. The relatively high nitrate concentrations in water discharged to the Suwannee River at Convict Spring could be caused by leachate from septic tanks or from adjacent fertilized cropland. Phosphorus concentrations in ground water beneath the monitored dairy farms and in water discharged at the three springs were generally at background concentrations, indicating that phosphorus from livestock-wastes was sorbed in the unsaturated zone or on aquifer materials, and that nitrate was the primary nutrient discharged to the Suwannee River at these springs.

To investigate the possible sources of nitrate in water from wells and springs, nitrogen isotope ratios were analyzed in water from 9 of the 51 monitoring wells and in water from Blue, Telford, and Convict springs. Nitrogen isotope ratios for nitrate in water samples collected from eight of the dairy-farm monitoring wells in July 1991 indicated that animal wastes were the principal source of nitrate in ground water immediately adjacent to wastewater lagoons and intensive livestock-use areas. Synthetic fertilizers, or combinations of leachate from synthetic fertilizers, soil nitrogen, and livestock wastes were the sources of nitrate in water from wells in pastures and wastewater spray fields. Differences of nitrogen-isotope ratios in nitrate in water from two well pairs (one shallow and one about 20 feet deeper in each pair) indicated that the water sampled from these wells was recharged from different land-use areas. Enrichment of the heavier ${ }^{15} \mathrm{~N}$ atoms in nitrate, either by ammonia volatilization or by denitrification, was indicated by the relatively high $\delta^{15} \mathrm{~N}$ values in water samples from wells $1-1,1-4 \mathrm{~B}$, and 
2-6A. Nitrogen isotope ratios in nitrate also indicated that leachate from livestock wastes or from septic tanks was to be the principal source of nitrate in ground water discharged to the Suwannee River at Blue, Telford, and Convict Springs.

Nitrate can be removed from ground water by microbial denitrification, by which bacteria in the presence of carbon sources in anoxic water remove oxygen atoms from nitrate for respiration. Although counts of denitrifying bacteria in water samples from selected monitoring wells at dairy farms commonly exceeded several hundred thousand colonies per 100 milliliters, oxygen concentrations in water samples from most of the monitoring wells were greater than $1.0 \mathrm{mg} / \mathrm{L}$, indicating that denitrification would not occur in water from most of these wells. Denitrification was more likely to occur in deeper ground water, which generally had lower dissolved oxygen concentrations than shallow ground water. Time-series measurements of nitrate, nitrite, and dissolved oxygen in two water samples taken from a dairy-farm monitoring well completed in the Upper Floridan aquifer indicated that denitrification may have been limited by lack of carbon substrate or by the presence of oxygen. Relatively low $\mathrm{pH}$ 's may have impeded denitrification in a water sample from a monitoring well completed in a sandy surficial aquifer.

\section{REFERENCES}

Adolphson, D.G., Ruhl, J.F., and Wolf, R.J., 1981, Designation of principal water-supply aquifers in Minnesota: U.S. Geological Survey Water-Resources Investigations Report 81-51, 19 p.

Alhajjar, B.J., Harkin, J.M., and Chesters, G., 1987, Chemical tracers of pollution plumes from septic systems receiving two types of detergents, in NWWA FOCUS Conference on Northwestern Ground Water Issues, 1987, Proceedings: Dublin, Ohio, National Water Well Association, p. 527-555.

Almendinger, J.E., 1991, Relation of nitrate concentrations in water to agricultural land use and soil type in Dakota County, Minnesota, 1990: U.S. Geological Survey Open File Report 91-235, 2 p.

Andrews, W.J., 1992, Reconnaissance of water quality at nine North Florida dairy farms, 1990-91: U.S. Geological Survey Water-Resources Investigations Report 92-4058, 39 p.

Bachman, L.J., Nitrate in the Columbia Aquifer, central Delmarva Peninsula, Maryland: U.S. Geological Survey Water-Resources Investigations Report 84$4322,51 \mathrm{p}$.
Bashkin, V.N., and Kudeyarov, V.N., 1983, Nitrate content of ground waters in agricultural areas of the Oka River basin: Soviet Soil Science, v. 15, no. 11, p. 41-47.

Bottcher, J., Strebel, O., Voerkelius, S., and Schmidt, H.L., 1990, Using isotope fractionation of nitrate-nitrogen and nitrate-oxygen for evaluation of microbial denitrification in a sandy aquifer: Journal of Hydrology, v. 114, p. 413-424.

Bradley, P.M, Aelion, C.M., and Vroblesky, D.A, 1992, Influence of environmental factors on denitrification in sediment contaminated with JP-4 jet fuel: Ground Water, v. 30, p. 843-848.

Britton, L.J., and Greeson, P.E., eds., 1987, Methods for collection and analysis of aquatic biologic and microbiological samples: U.S. Geological Survey Techniques of Water-Resources Investigations, Book 5, Chap. A4, 363 p.

Brooks, H.K., 1981a, Physiographic divisions of Florida: Center for Environmental and Natural Resources, Florida Cooperative Extension Service, Institute of Food and Agricultural Sciences, Gainesville, University, 1 sheet with guidebook.

_, $1981 \mathrm{~b}$, Geologic map of Florida: Center for Environmental and Natural Resources, Florida Cooperative Extension Service, Institute of Food and Agricultural Sciences, Gainesville, University, 1 sheet.

Burke, I.C., Mosier, A.R., Porter, L.K., and O'Deen, L.A., 1990, Diffusion of soil extracts for nitrogen and nitrogen- 15 analyses by automated combustion/mass spectrometry: Soil Science Society of America Journal, vol. 54, p. 1190-1192.

Ceryak, R., Knapp, M.S., and Burnson, T., 1983, The geology and water resources of the Upper Suwannee River Basin, Florida: Florida Bureau of Geology Report of Investigations 87, 165, p.

Crane, J.J., 1986, An investigation of the geology, hydrology, and hydrochemistry of the Lower Suwannee River Basin: Florida Geological Survey Report of Investigations 96, 205 p.

Delwiche, C.C., and Steyn, P.L., 1970, Nitrogen isotope fractionation in soils and microbial reactions: Environmental Science and Technology, v. 4, p. 929935.

Dorsch, M.M., and others, 1984, Congenital malformations and maternal drinking water supply in rural South Australia: a case-control study: American Journal of Epidemiology, v. 119, p. 473-480.

Ericksen, G.E., 1981, Geology and origin of the Chilean nitrate deposits: U.S. Geological Survey Professional Paper 1188, 37 p.

Exner, M.E., and Spalding, R.F., 1990, Occurrence of pesticides and nitrate in Nebraska's ground water, 1990: Water Center, Institute of Agriculture and Natural Resources, the University of Nebraska, Publication WC1, $34 \mathrm{p}$. 
Fan, A.M., Wilhite, C.C., and Book, S.A., 1987, Evaluation of the nitrate drinking water standard with reference to infant methemoglobinemia and potential reproductive toxicity: Regulatory Toxicology and Pharmacology, v. 7, p. 135-137.

Fishel, D.K., and Lietman, P.L., 1986, Occurrence of nitrate and herbicides in ground water in the Upper Conestoga River Basin, Pennsylvania, Water-quality study of the Conestoga River Headwaters, Pennsylvania: U.S. Geological Survey, Water-Resources Investigations Report 85-4202, 8 p.

Fishman, M.J., and Friedman, L.C., eds., 1989, Methods for determination of inorganic substances in water and fluvial sediments: U.S. Geological Survey Techniques of Water-Resources Investigations, Book 5, Chap. A1, $545 \mathrm{p}$.

Florida Agricultural Statistics Service, 1992, Florida cattle county estimates, January, 1992: Orlando, Florida Department of Agriculture and Consumer Services, $2 \mathrm{p}$.

Florida Department of State, 1993, Rules of the Department of Environmental Regulation, public drinking water systems: Tallahassee, Chapter 17-550, in Florida Administrative Code.

Forman, D., Al-Dabbagh, S., and Doll, R., 1985, Nitrates, nitrites and gastric cancer in Great Britain: Nature, v. 313 , p. $620-625$.

Hallberg, G.R., Libra, R.D., and Hoyer, B.E., 1985, Nonpoint source contamination of ground water in karst-carbonate aquifers in Iowa in Perspectives on Nonpoint Source Pollution, Proceedings of a National Conference, Kansas City, Mo. May 19-22, I985: U.S. Environmental Protection Agency, EPA 440/5-85-001, p. 109-114.

Hallberg, G.R., 1987, Rural groundwater contamination: Chelsea, Michigan, Lewis Publishers, p. 23-68.

Hallberg, G.R., 1989, Nitrate in ground water in the United States, in Nitrogen Management and Ground Water Protection, Developments in Agricultural and Managed-Forest Ecology 21: New York, Elsevier, p. 35-74.

Hauck, R.D., 1982, Nitrogen-isotope-ratio analysis, in Methods of soil analysis, part 2--Chemical and microbiological properties--Agronomy monograph no. 9, second ed.: Madison, Wisc., Soil Science Society of America, p. 735-779.

Hindall, S.M., 1978, Effects of irrigation on water quality in the sand plain of central Wisconsin: Wisconsin Geological and Natural History Survey, Information Circular No. 36, $50 \mathrm{p}$.
Johnston, W.R., 1985, Irrigated agriculture and nonpoint source pollution in the San Joaquin Valley of California in Perspectives on Nonpoint Source Pollution, Proceedings of a National Conference, Kansas City, Mo. May 19-22, 1985: U.S. Environmental Protection Agency, EPA 440/5-85-001, p. 276-278.

Knapp, M.S., 1978, Environmental geology series-Valdosta Sheet: Florida Department of Natural Resources, Bureau of Geology Map Series No. 88, 1 sheet.

Korom, S.F., I992, Natural denitrification in the saturated zone: a review: Water Resources Research, v. 28, no. 6, p. 1657-1668.

Krietler, C.W., 1975, Determining the source of nitrate in ground water by nitrogen isotope studies: Bureau of Economic Geology, University of Texas at Austin, Report of Investigations, no. 83, $57 \mathrm{p}$.

Lamb, C.E., 1986, National water summary 1986--Groundwater quality; California: U.S. Geological Survey Water-Supply Paper 2325, p. 173-I79.

Lind, A., 1985, Nitrate reduction in the subsoil, in Golterman, H.L., ed., Denitrification in the nitrogen cycle: Plenum Press, NY.

Madison, R.J., and Brunett, J.O., 1984, Overview of the occurrence of nitrate in ground water of the United States, in National Water Summary, 1984: U.S. Geological Survey Water Supply Paper 2274, Washington, D.C.

Meadows, P.E., 1991, Potentiometric surface of the Upper Floridan aquifer in the Suwannee River Water Management District, Florida: U.S. Geological Survey Open-File Report 90-582, 1 sheet.

Mirvish, S.S., 1990, The significance for human health of nitrate, nitrite, and $\mathrm{N}$-nitroso compounds: North Atlantic Treaty Organization Nitrate Conference, Lincoln, NB.

Morel, F.M.M., and Hering, J.G., 1993, Principles and applications of aquatic chemistry: John Wiley and Sons, Inc., NY, 588 p.

National Research Council, 1985, The health effects of nitrate, nitrite, and N-nitroso compounds: National Academy of Sciences, Washington, D.C.

Nier, A.D., 1955, Determination of isotopic masses and abundances by mass spectrometry: Science, v. 121, p. 737-744.

Obenhuber, D.C., and Lowrance, R., 1991, Reduction of nitrate in aquifer microcosms by carbon additions: Journal of Environmental Quality, v. 20, p. 255-258.

Page, R.W., and Balding, B.O., 1973, Geology and quality of water in the Modesto-Merced area, San Joaquin Valley, California, with a brief section on hydrology: U.S. Geological Survey Water-Resources Investigation 5-73. 
Parker, J.M., Booth, S.K., and Foster, S.S.D., 1987, Penetration of nitrate from agricultural soils into the groundwater of the Norfolk Chalk: Proceedings of Institutional Civil Engineers, v. 83, pt. 2, p. 15-32.

Pedersen, J.K., Bjerg, P.L., and Christensen, T.H., 1991, Correlation of nitrate profiles with groundwater and sediment characteristics in a shallow sandy aquifer: Journal of Hydrology, v. 124, no. 3/4, p. 263-277.

Pekny, V., Skorepa, J., and Vrba, J., 1989, Impact of nitrogen fertilizers on groundwater quality--some examples from Czechoslovakia: Journal of Contaminant Hydrology, v. 4, p. 51-67.

Portage County Planning Department, 1988, Inventory and analysis of county ground water resources, problems, and needs, Portage County ground water management plan, v. 1: Stevens Point, Wisconsin, Portage County Planning Department.

Poth, C.W., 1977, Summary groundwater resources of Lancaster County, Pennsylvania: Pennsylvania Department of Environmental Resources, Water Resources Report 43, Harrisburg, Penn.

Rantz, S.E., and others, 1982, Measurement and computation of stream flow; v. 1--Measurement of stage and discharge: U.S. Geological Survey, WaterSupply Paper 2175, $284 \mathrm{p}$.

Saffigna, P.G., and Keeney, D.R., 1977, Nitrate and chloride in ground water under irrigated agriculture in central Wisconsin: Ground Water, v. 15, p. 170-177.

Smith, R.L., and Duff, J.H., 1988, Denitrification in a sand and gravel aquifer: Applied Environmental Microbiology, v. 54, p. 1071-1078.

Stringfield, V.T., 1935, The piezometric surface of artesian water in the Florida Peninsula: American Geophysical Union Transactions, Sixteenth Annual Meeting, p. 524-529.

Taylor, L.E., and Werkheiser, W.H., 1984, Groundwater resources of the Lower Susquehanna River Basin, Pennsylvania: Pennsylvania Department of Environmental Resources, Water Resources Report 57, Harrisburg, Penn.
U.S. Soil Conservation Service, 1993a, South east middle Suwannee River Area-Watershed protection plan and environmental assessment: Gainesville, Fla., [variously paged].

U.S. Soil Conservation Service, 1993b, North west middle Suwannee River Area--Watershed protection plan and environmental assessment: Gainesville, Fla., [variously paged].

Vigil, J., Warbuton, S., Haynes, W.S., and Kaiser, L.R., 1965 , Nitrates in municipal water supply cause methemoglobinemia in infant: Public Health Report, v. 80 , no. 12 , p. $119-121$.

Vogel, A.I., 1961, Quantitative inorganic analysis: New York, John Wiley and Sons, $1216 \mathrm{p}$.

Watkins, S.H., Strand, R.F., Debel, D.S., and Esch, J., Jr., 1972, Factors influencing ammonia losses from urea applied to northwestern forest soils: Soil Society of America Proceedings, v. 36, p. 354-357.

Weil, R.R., Weismiller, R.A., and Turner, R.S., 1990, Nitrate contamination of groundwater under irrigated coastal plain soils: Journal of Environmental Quality, v. 19 , no. 3, p. 441-448.

Wellman, R.P., Cook, F.D., and Krouse, H.R., 1968, Nitrogen-15: microbial alteration of natural abundance: Science, v. 161, p. 269-270.

Wilson, G.B., Andrews, J.N., and Bath, A.H, 1990, Dissolved gas evidence for denitrification in the Lincolnshire Limestone groundwaters, eastern England: Journal of Hydrology, v. 113, p. 51-60.

Wood, W.W., 1976, Guidelines for collection and field analysis of ground-water samples for selected unstable constituents: U.S. Geological Survey Techniques of Water-Resources Investigations, Book 1, Chap. D2, $23 \mathrm{p}$. 
APPENDIX I 
40 Nitrate in Ground Water and Spring Water near Four Dalry Farms inNorth Florida, 1990-93 


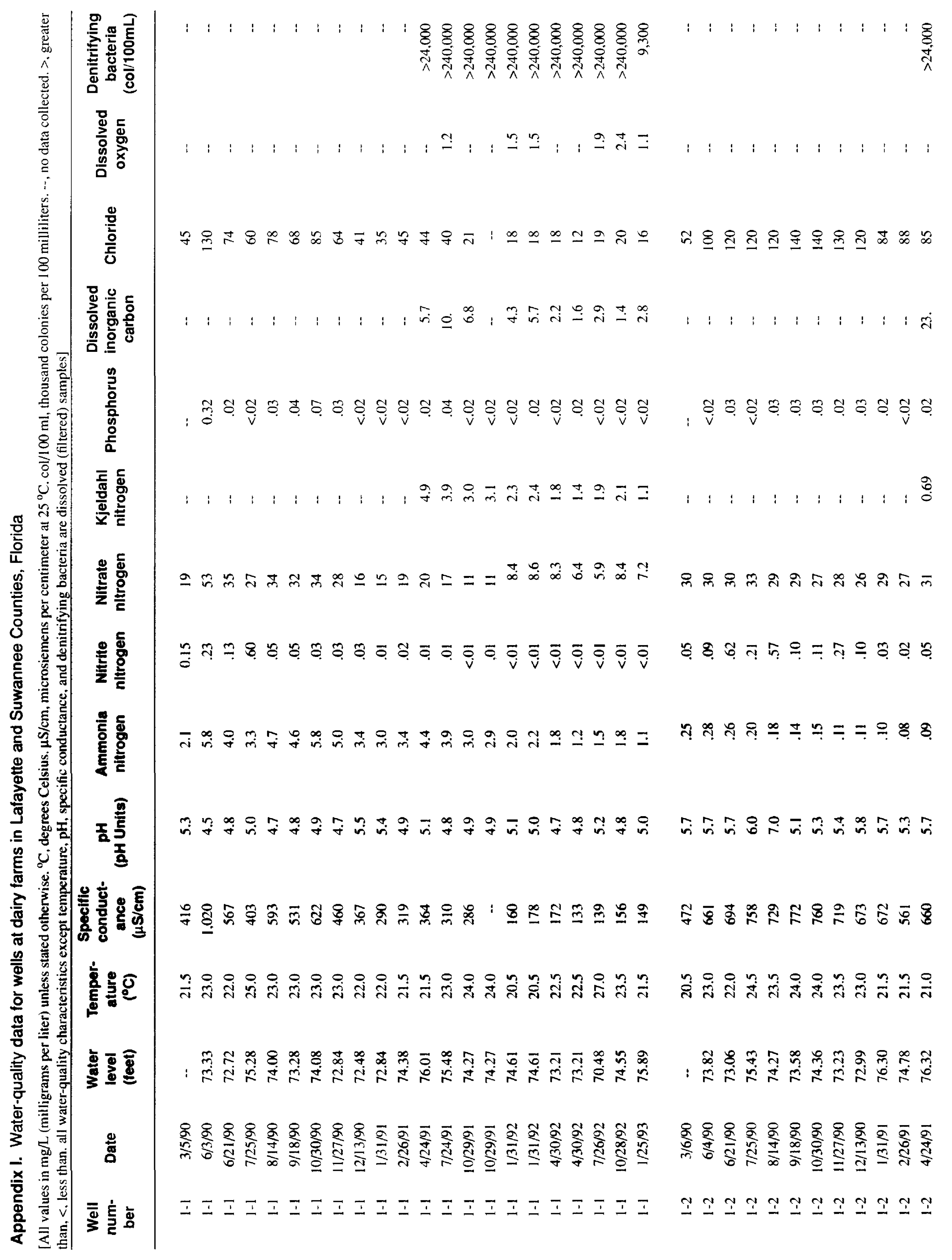




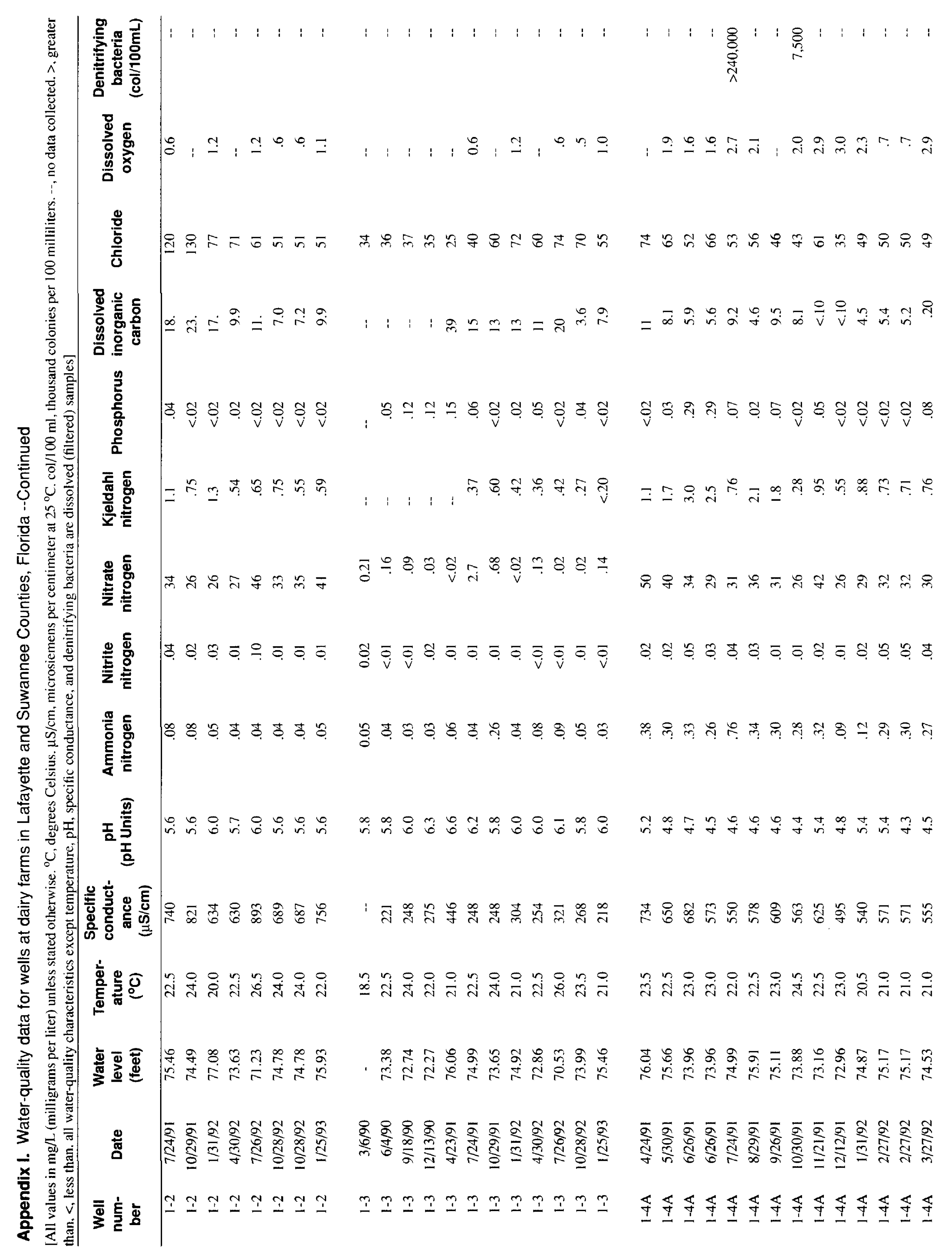




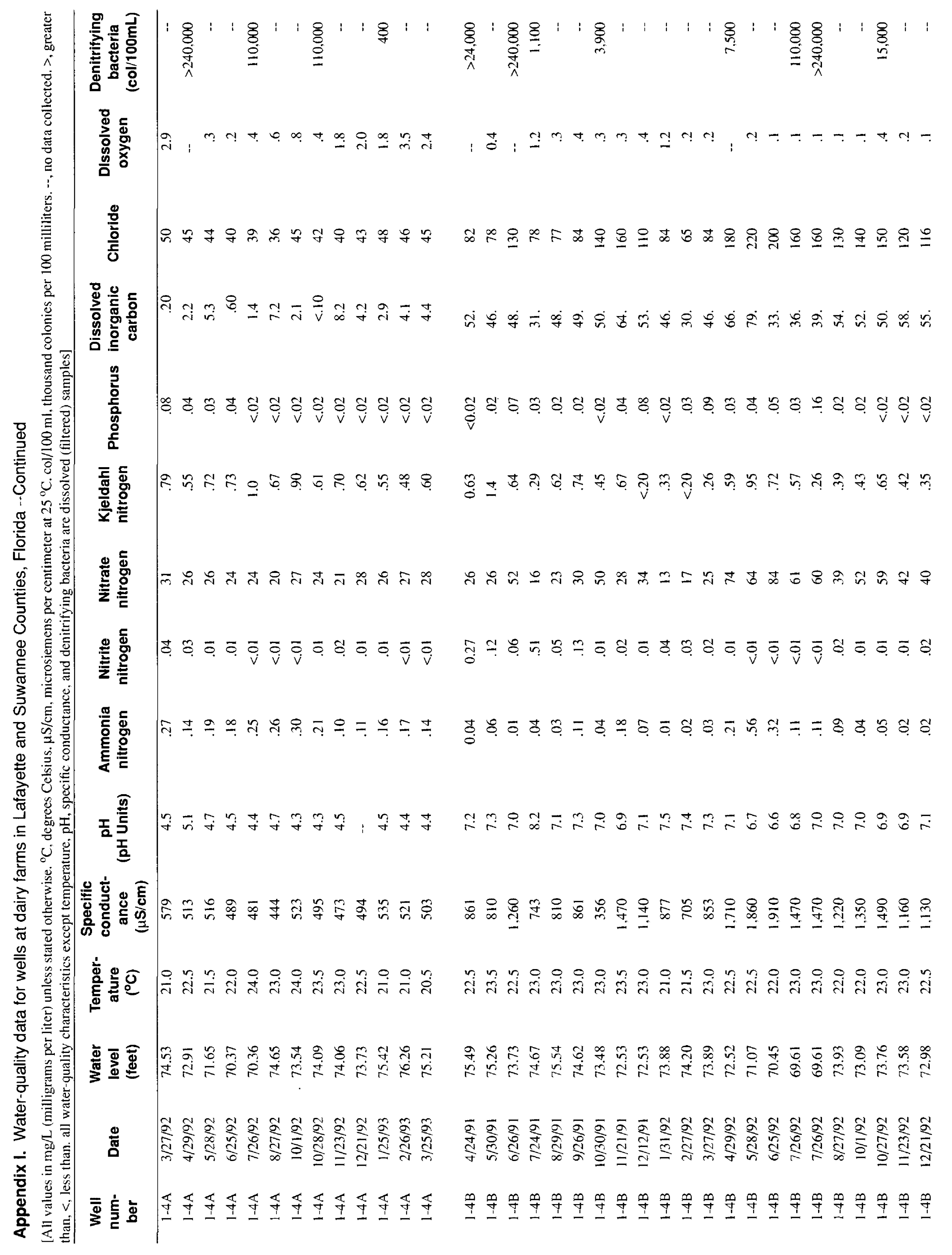




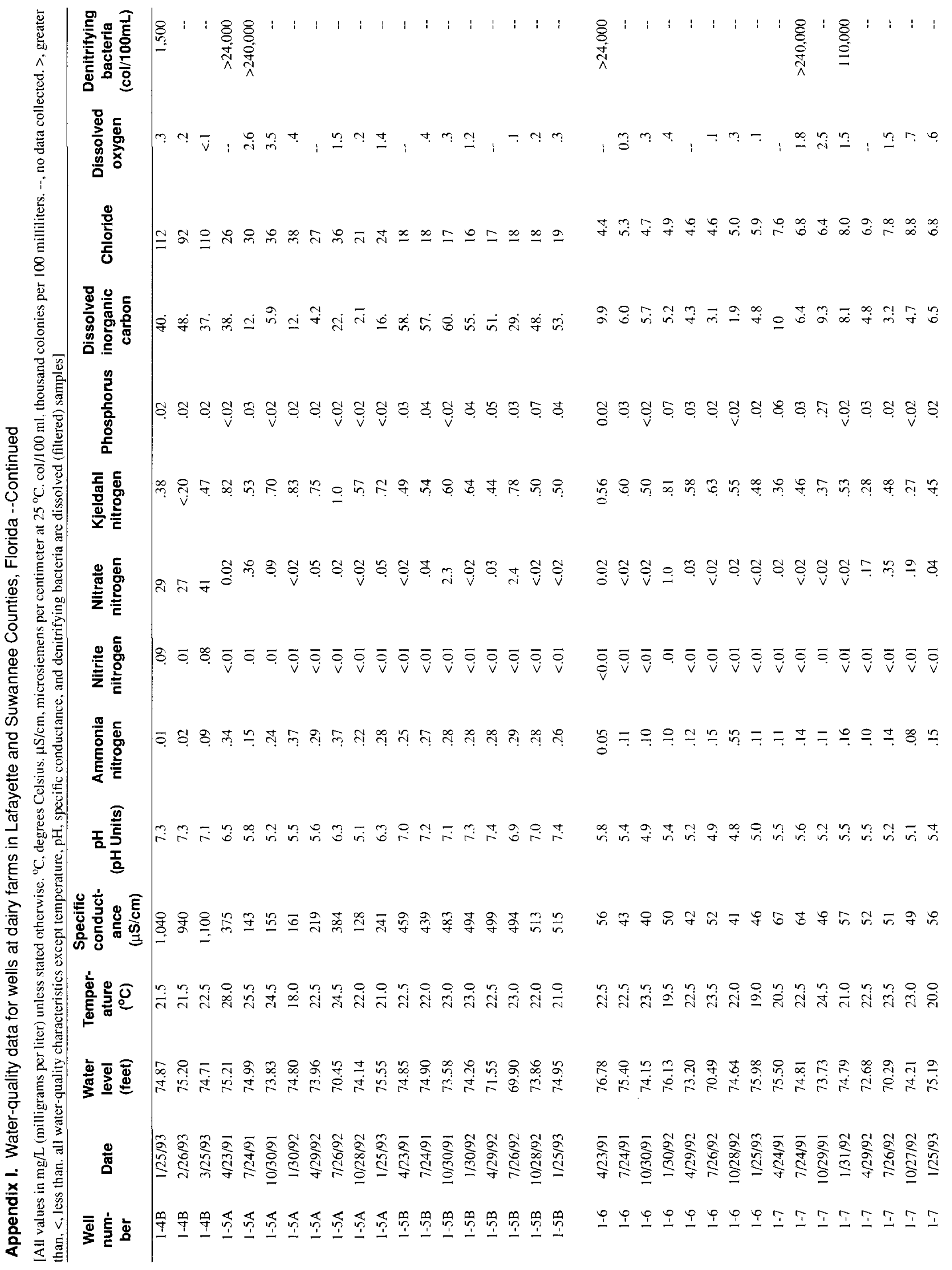




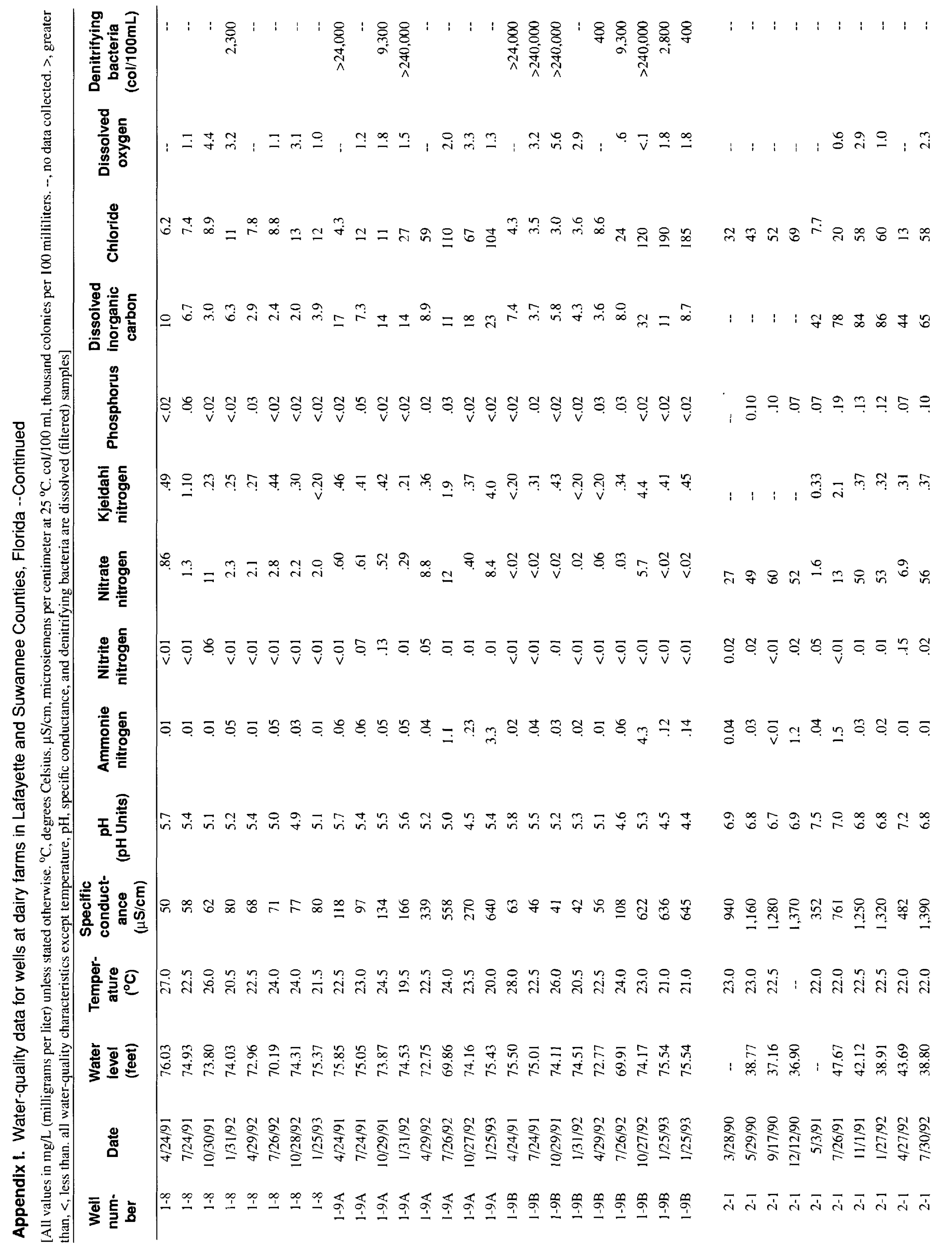




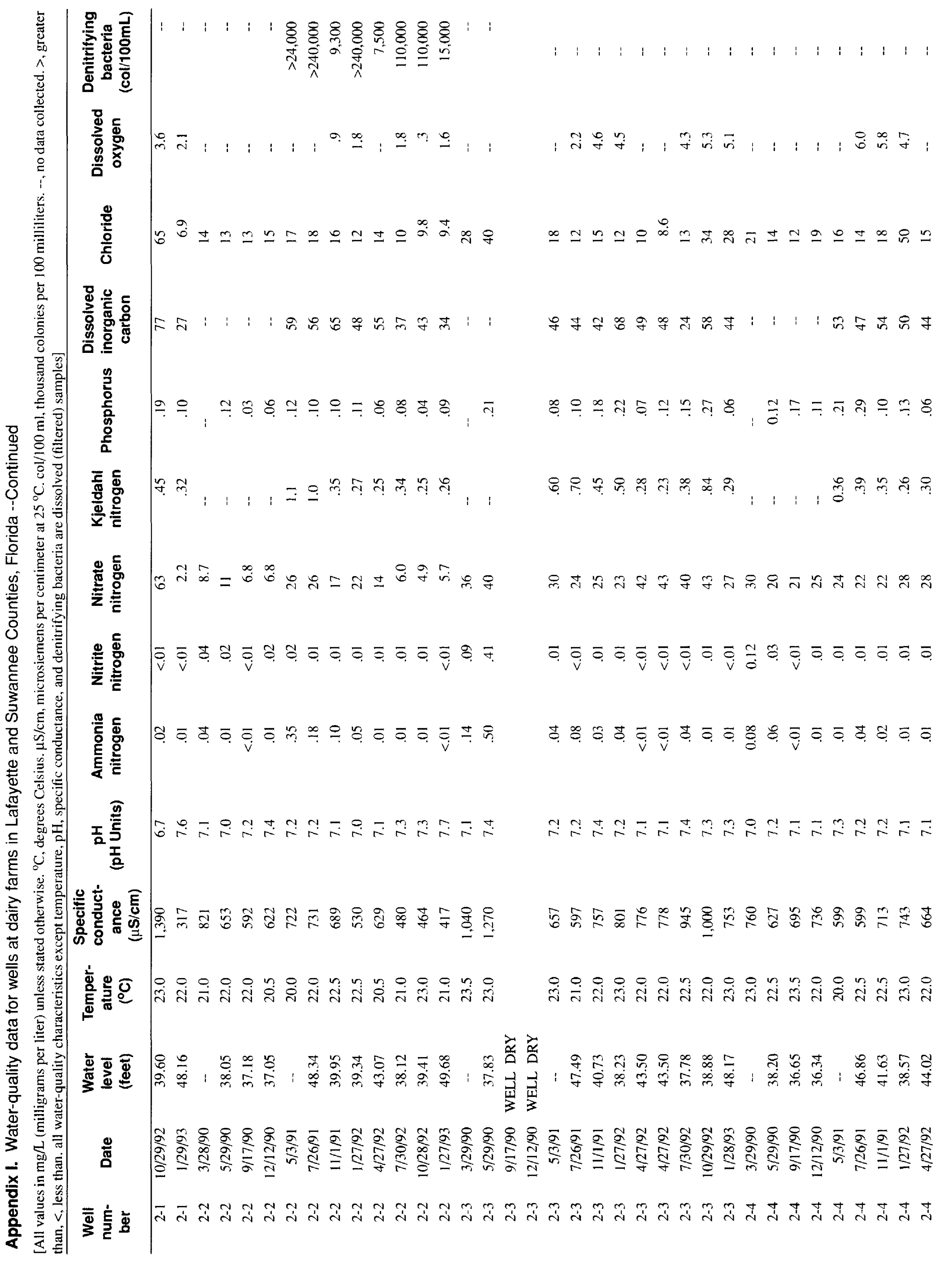




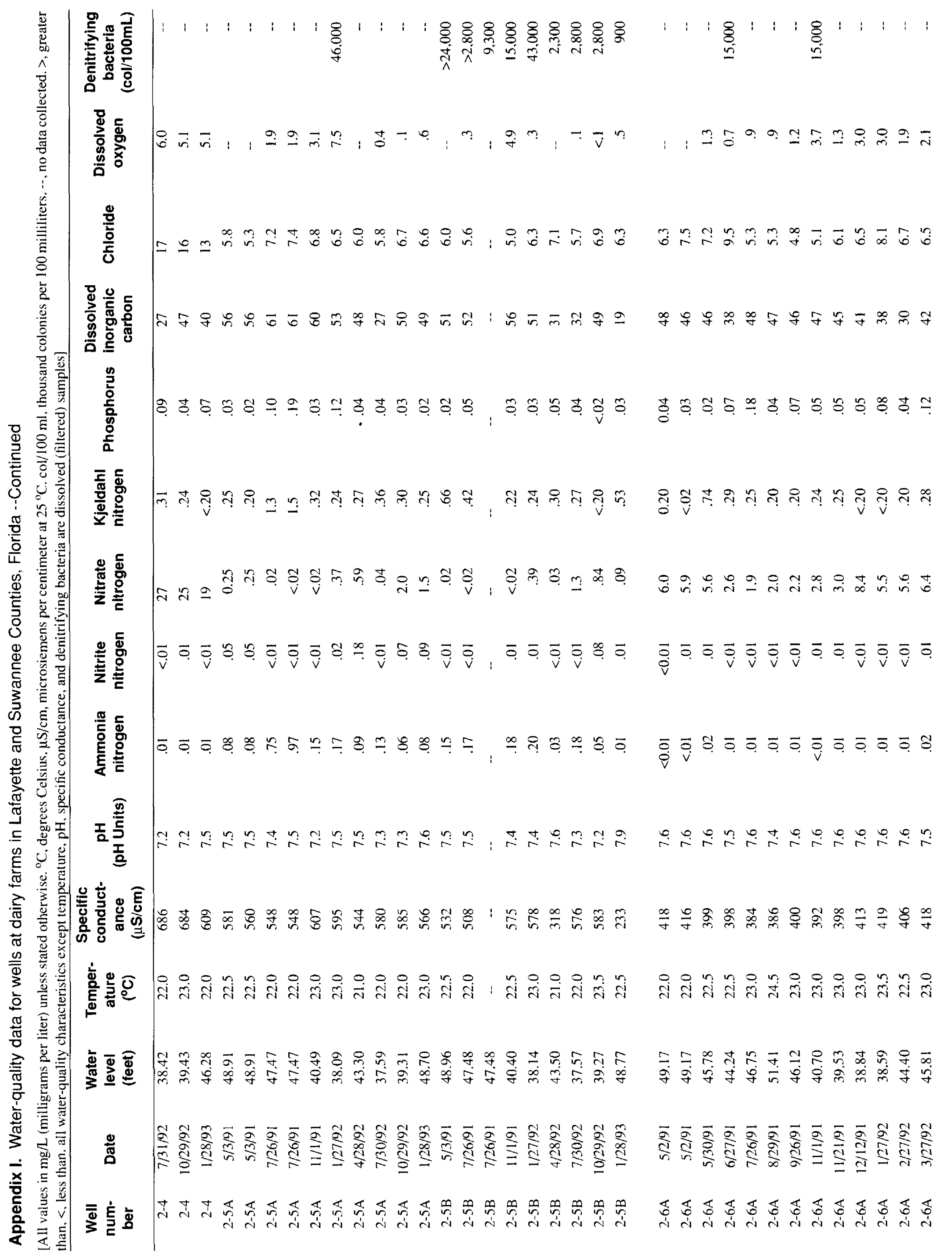




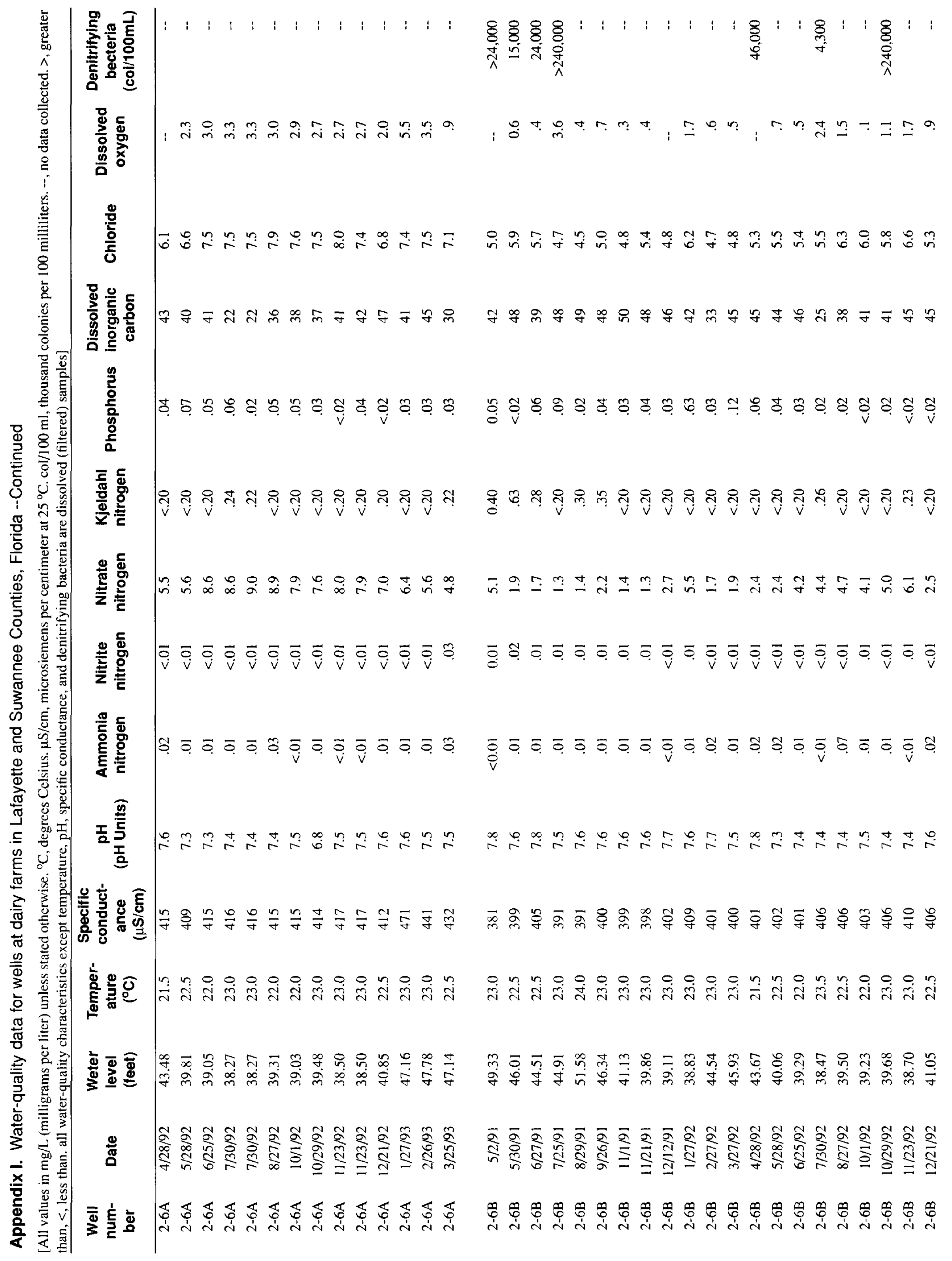




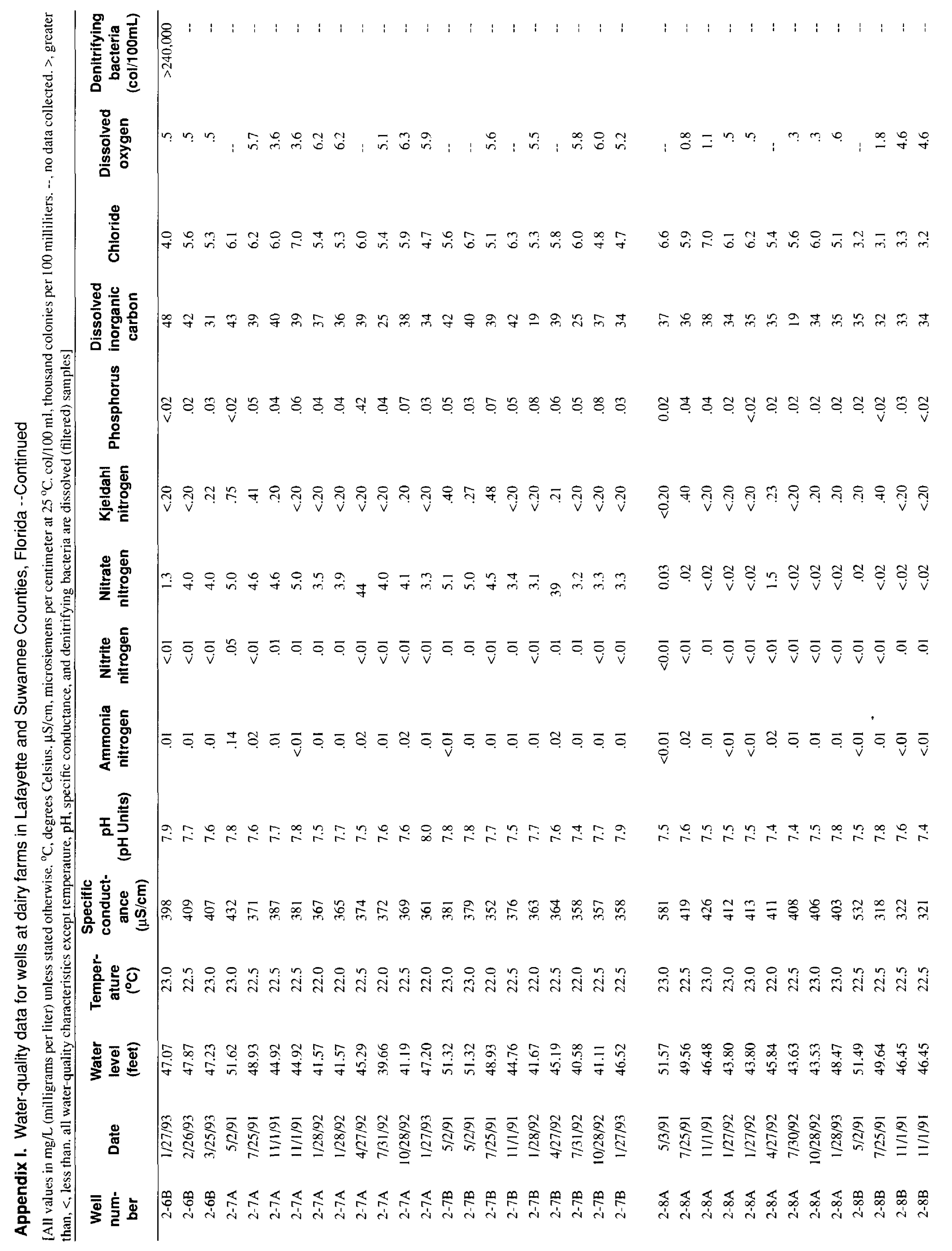




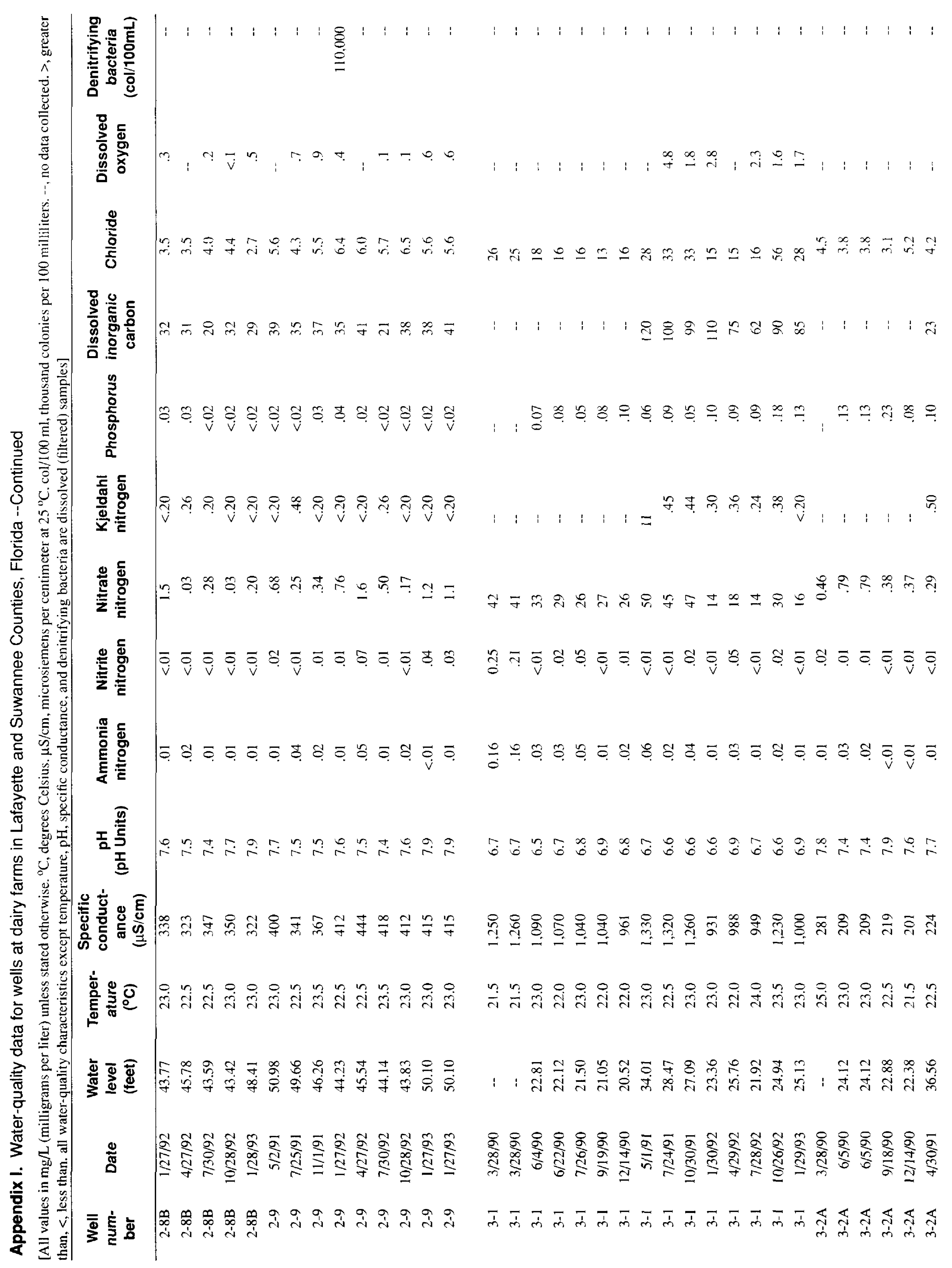




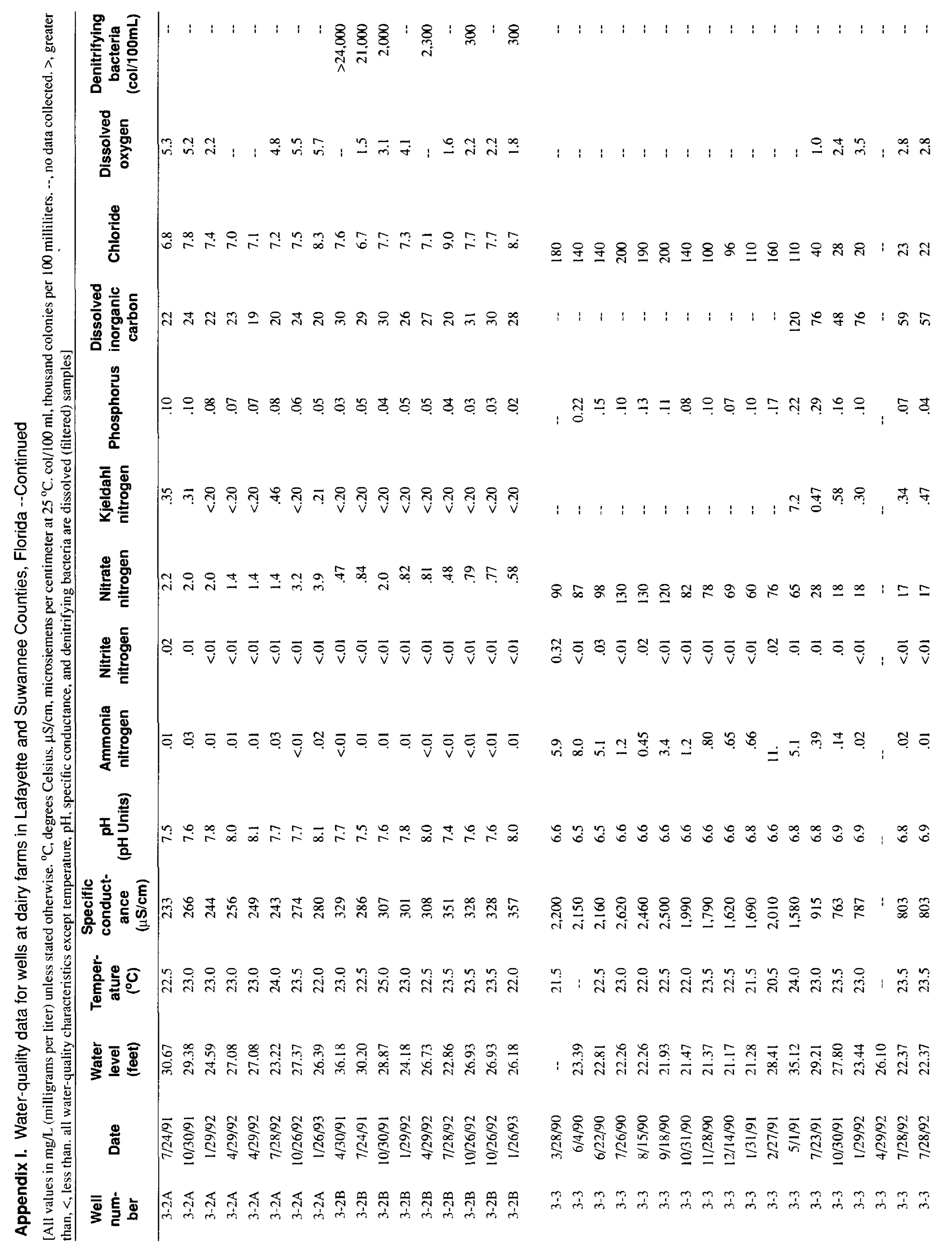




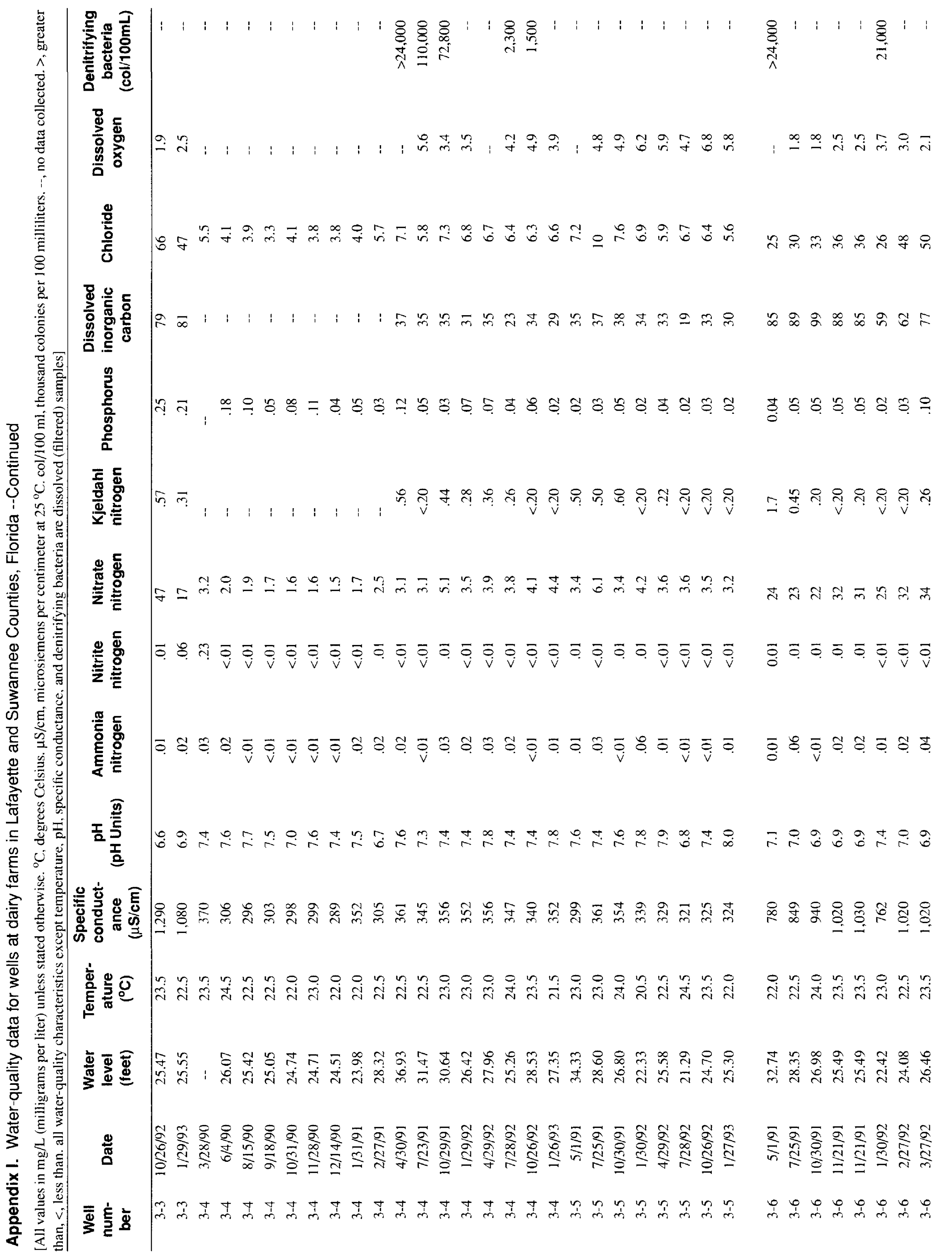




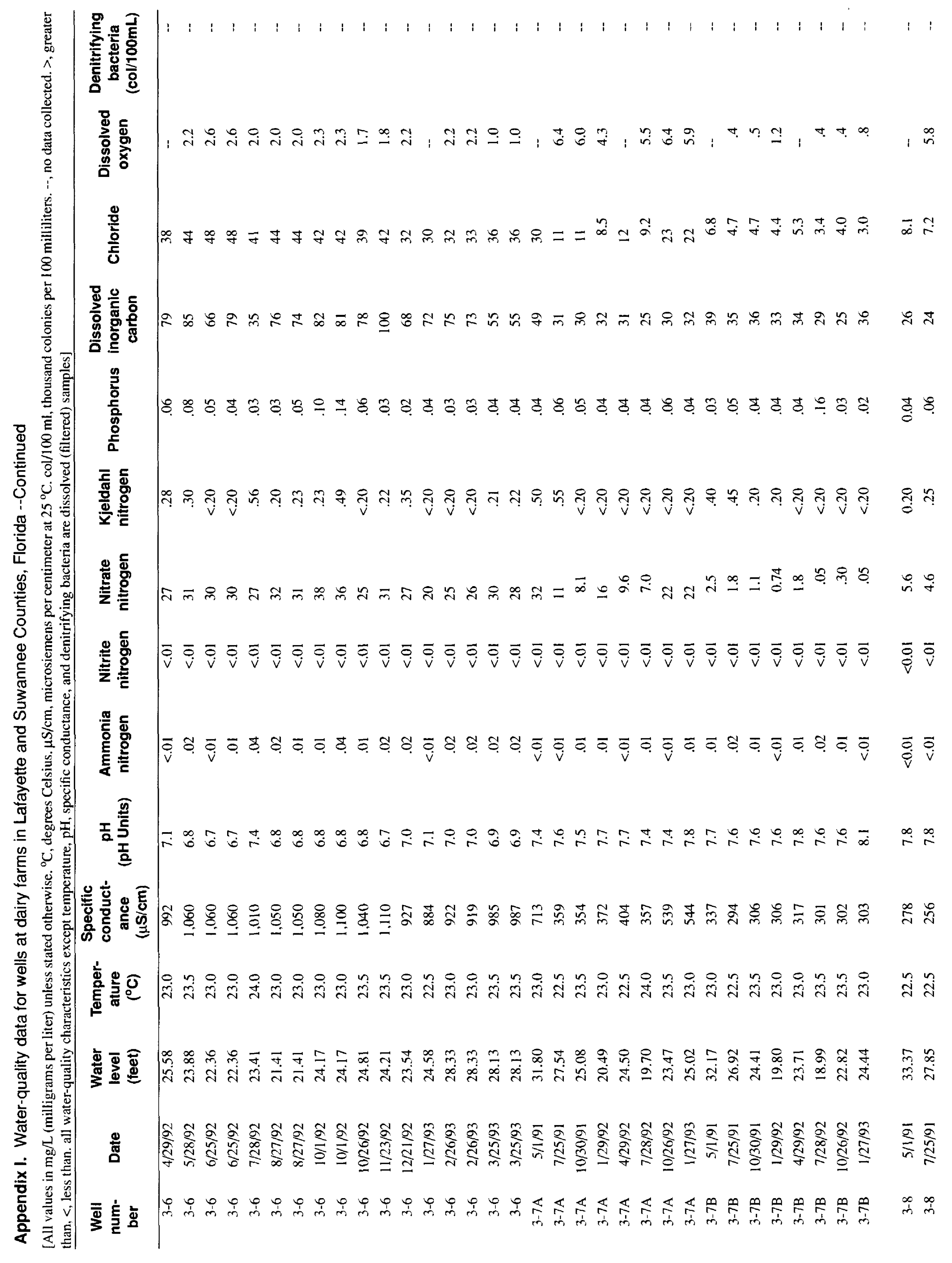




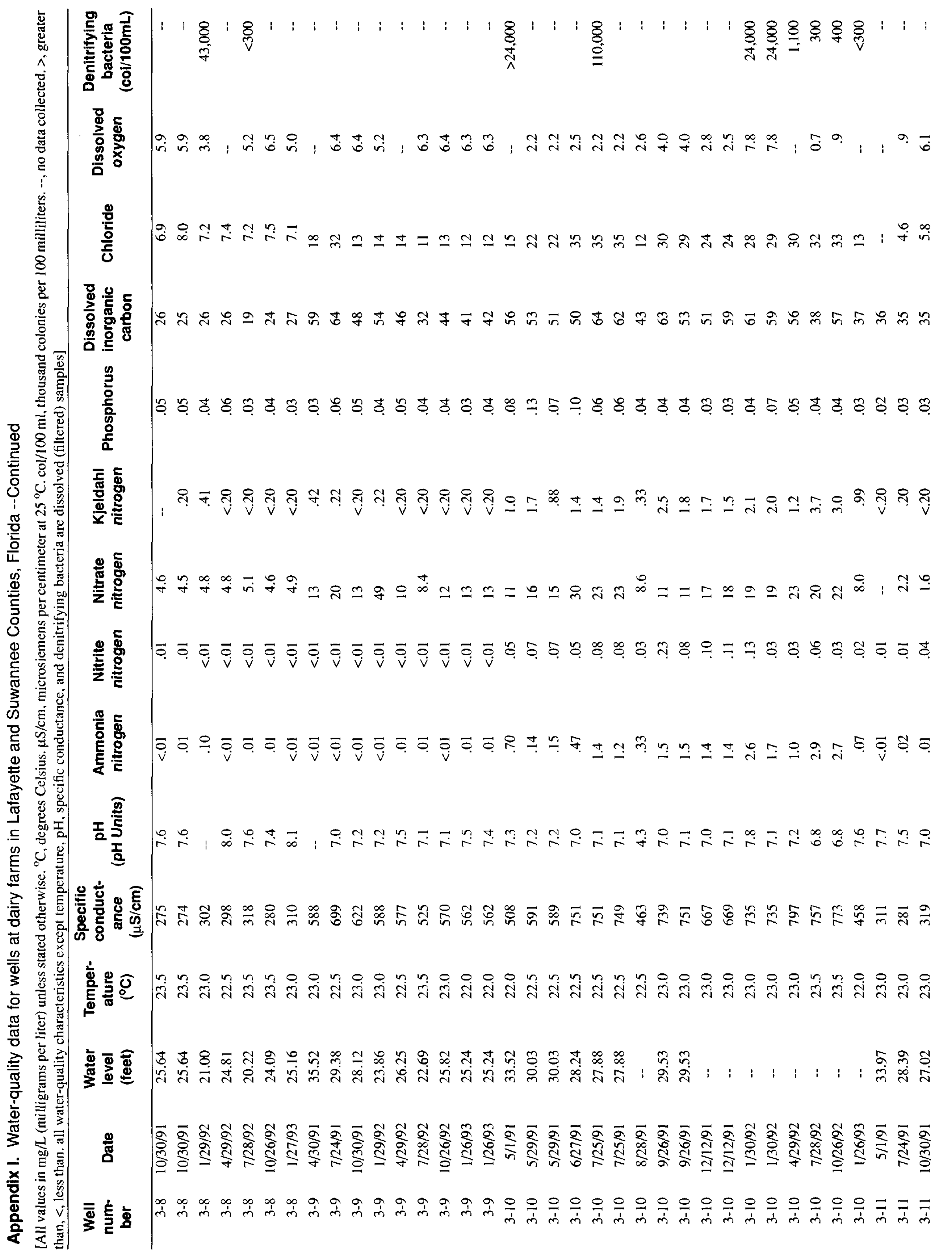




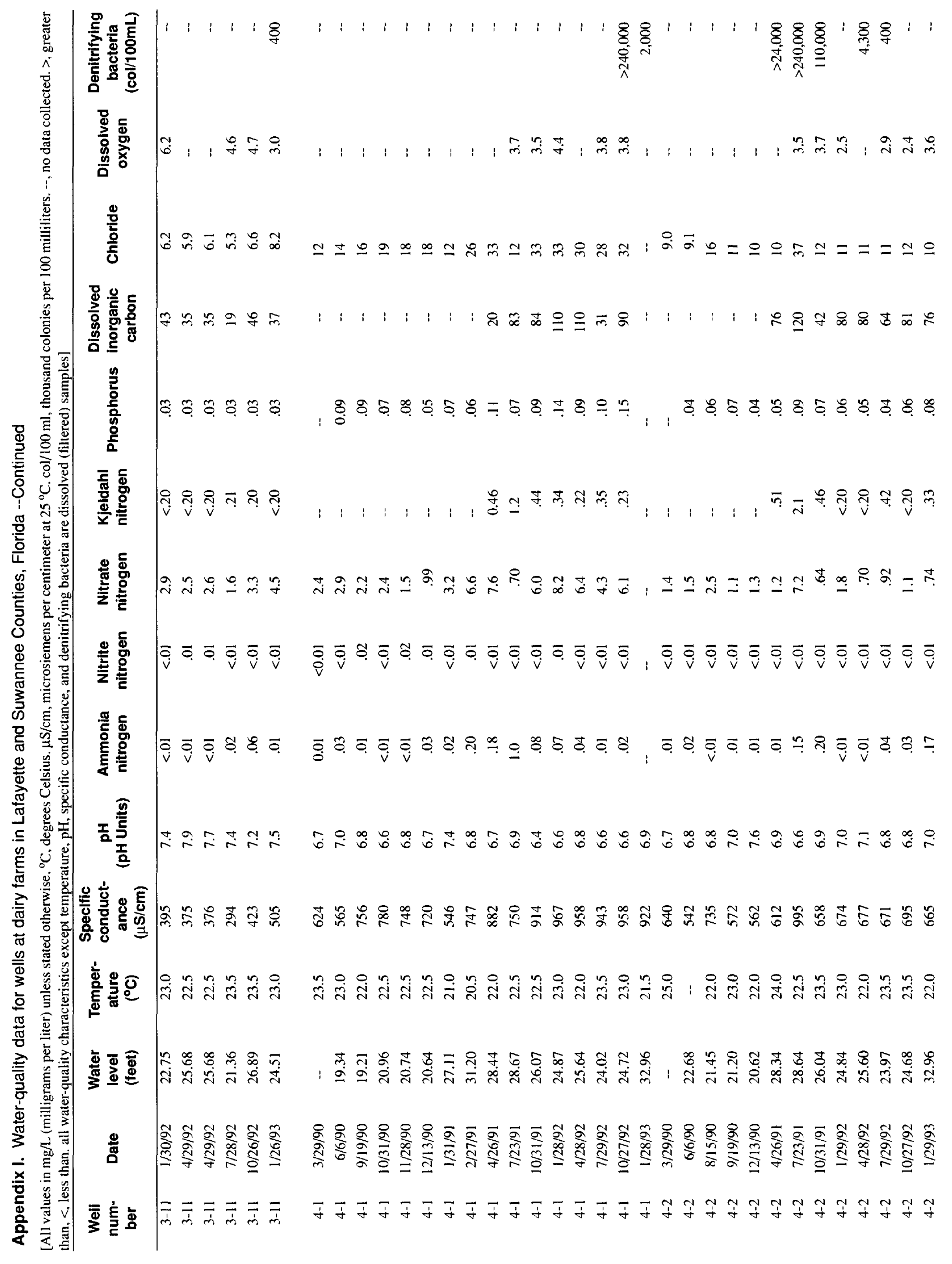




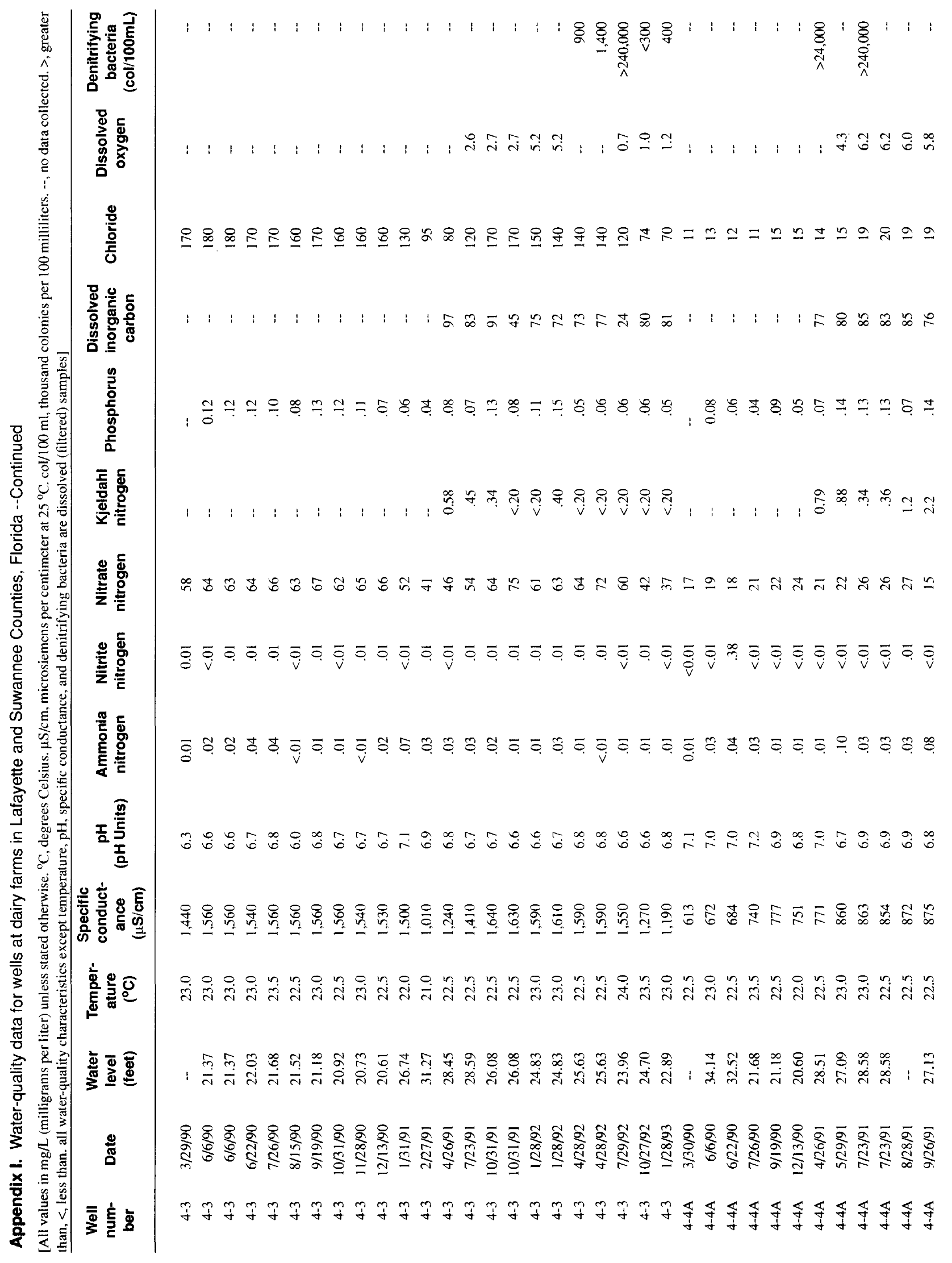




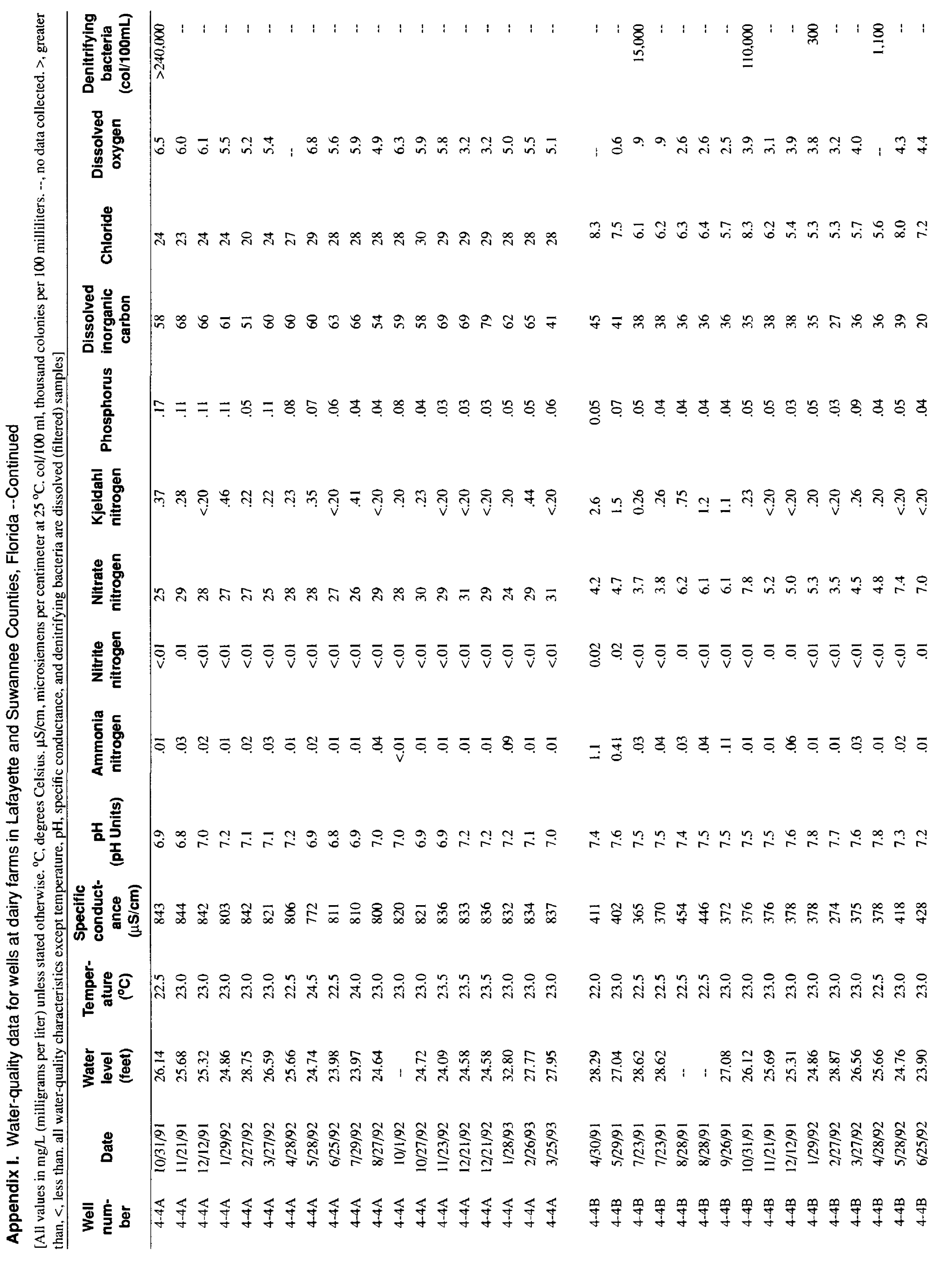




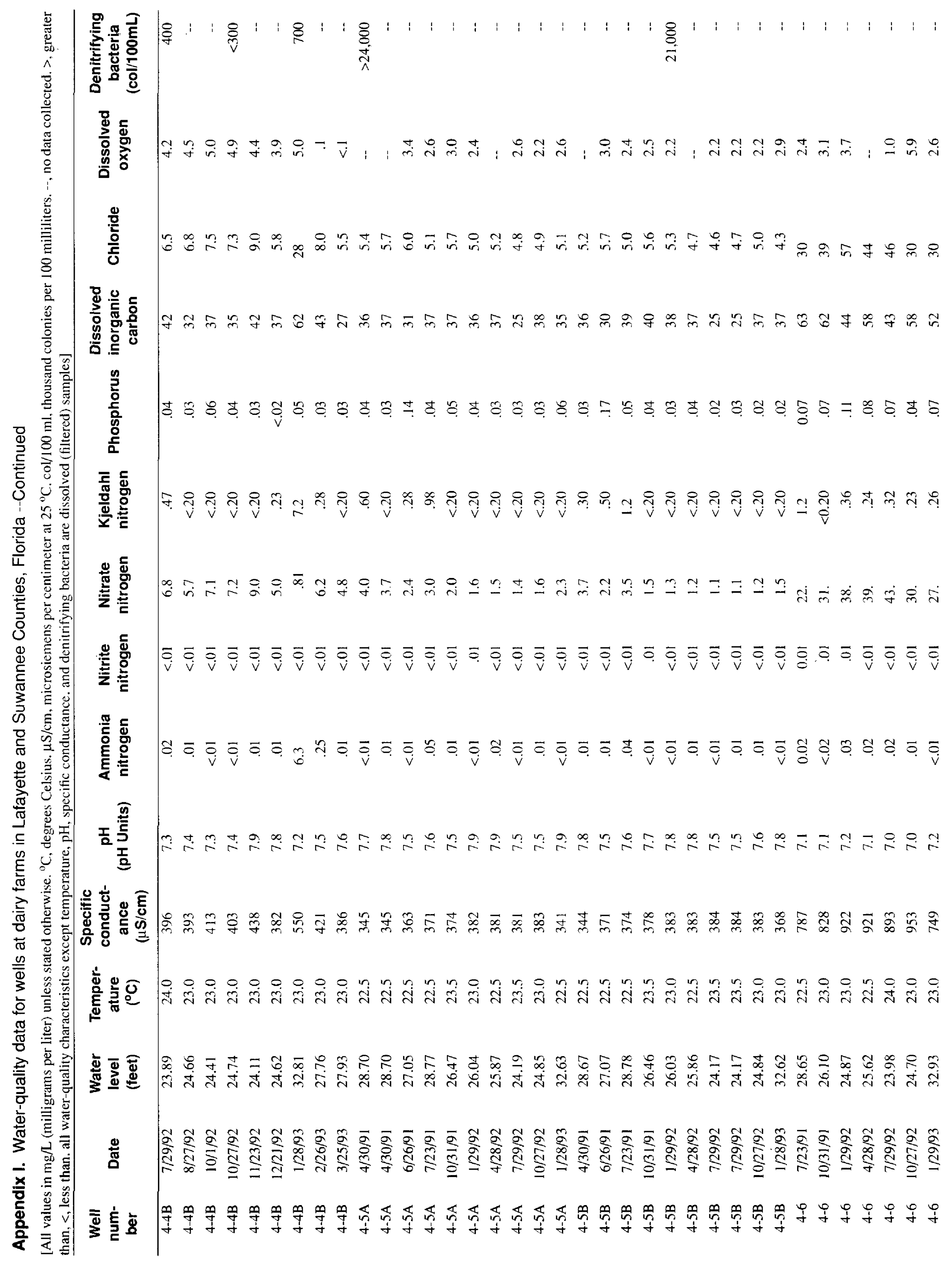




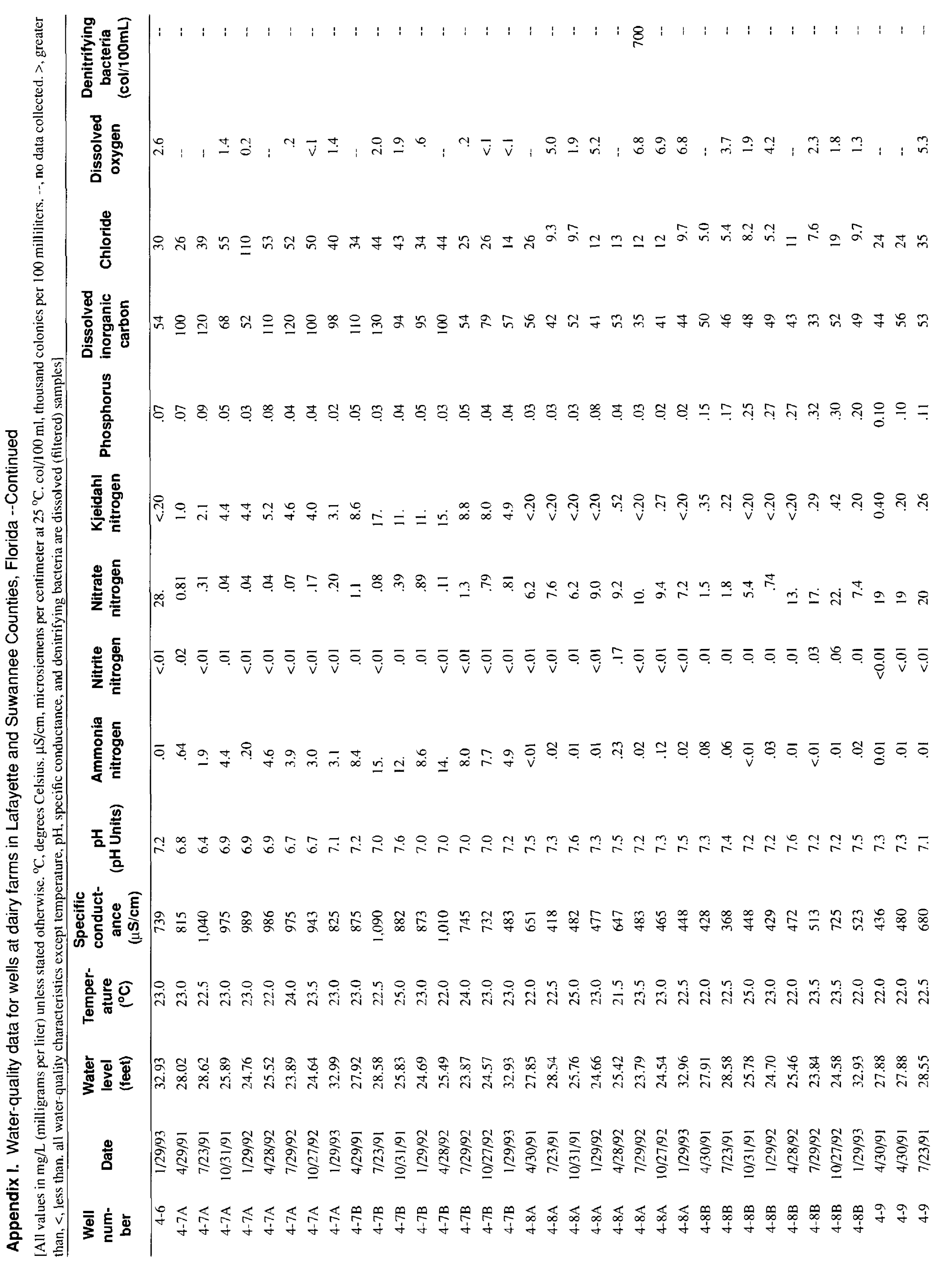




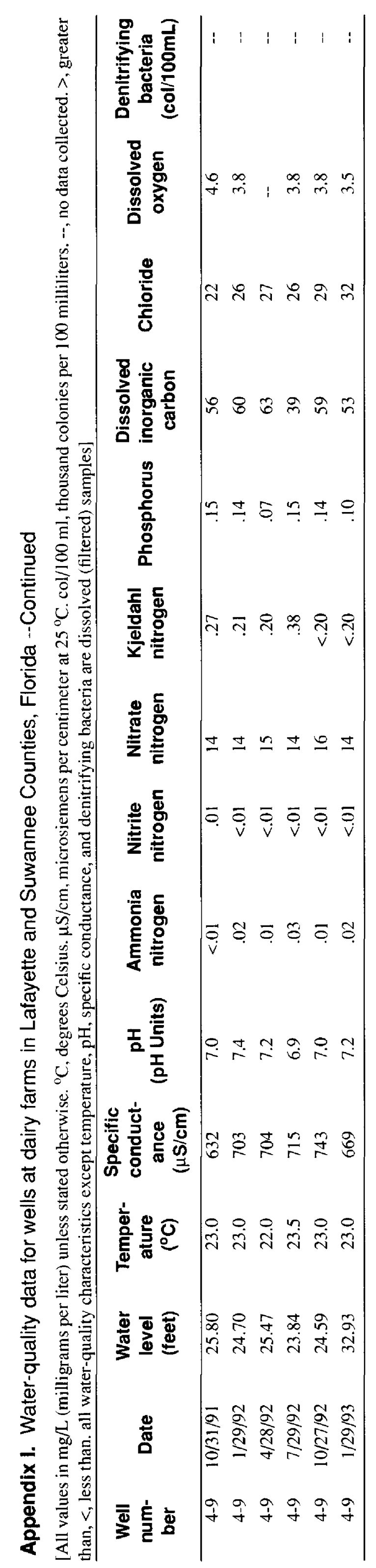


APPENDIX II

(ampe 63 follows) 


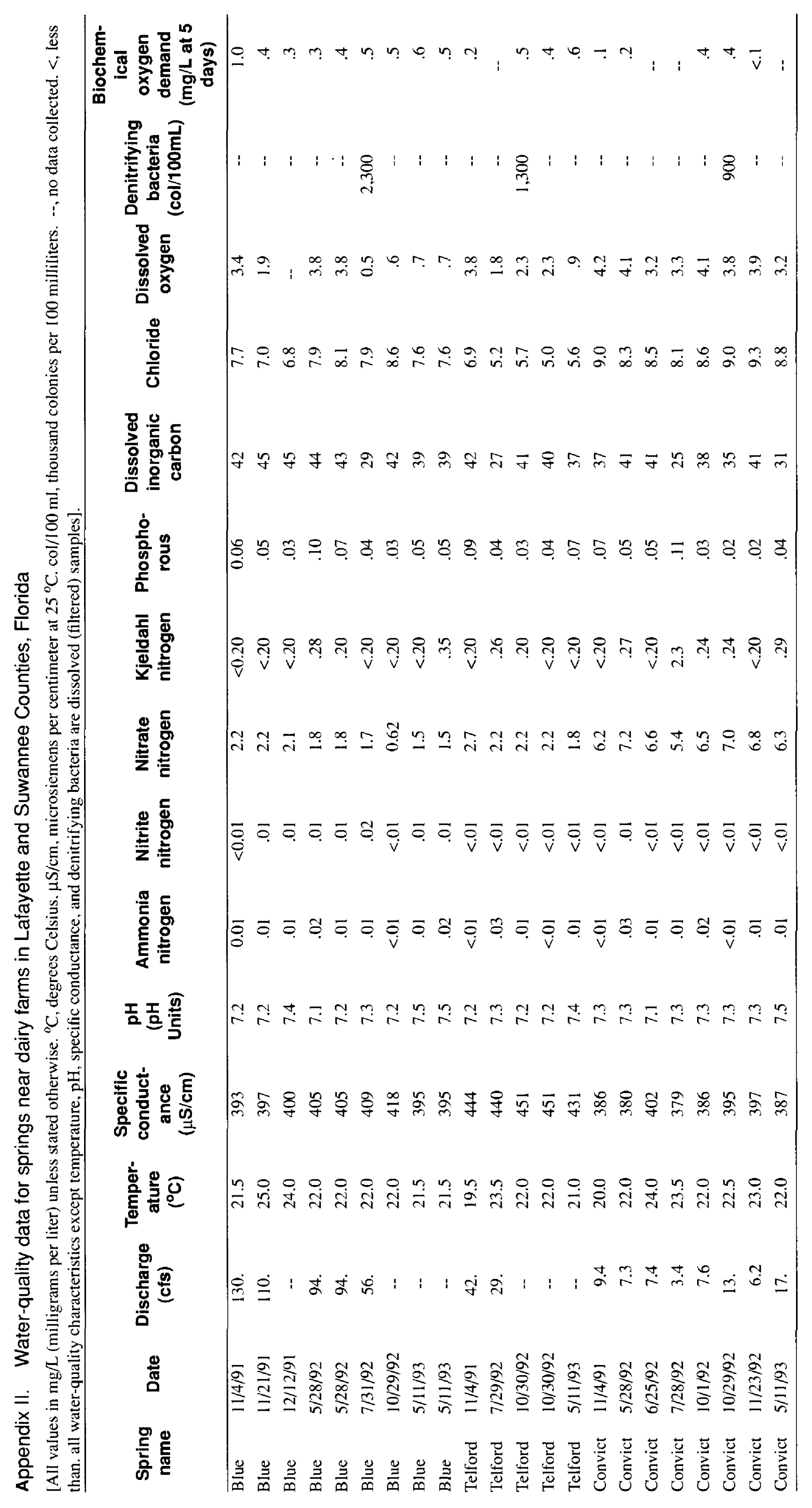

